UNIVERSIDADE DE SÃO PAULO

FACULDADE DE ARQUITETURA E URBANISMO



\title{
A construção do Largo das Forras como Patrimônio - Tiradentes/MG
}


MARIANA ALVES MADUREIRA

A construção do Largo das Forras como Patrimônio Tiradentes/MG 


\section{A construção do Largo das Forras como Patrimônio- Tiradentes/MG}

Dissertação apresentada à Faculdade de Arquitetura e Urbanismo da Universidade de São Paulo para obtenção do título de Mestre em Arquitetura e Urbanismo.

Área de Concentração: História e Fundamentos Sociais da Arquitetura e do Urbanismo

Orientadora: Prof. Dr. Ana Lúcia Duarte Lanna 
AUTORIZO A REPRODUÇÃO E DIVULGAÇÃO TOTAL OU PARCIAL DESTE TRABALHO, POR QUALQUER MEIO CONVENCIONAL OU ELETRÔNICO, PARA FINS DE ESTUDO E PESQUISA, DESDE QUE CITADA A FONTE.

E-MAIL: marianamadureira@usp.br

\begin{tabular}{|l|}
\hline Madureira, Mariana Alves \\
A construção do Largo das Forras como patrimônio/ \\
Mariana Madureira. -- São Paulo, 2011. \\
149p. : il. \\
Dissertação (Mestrado - Área de Concentração : \\
História e Fundamentos Sociais da Arquitetura e do \\
Urbanismo) - FAUUSP. \\
Orientadora: Ana Lúcia Duarte Lanna \\
$\begin{array}{l}\text { 1. Patrimônio - Tiradentes (MG) 2. Turismo - Tiradentes } \\
\text { (MG) 3. Valores I. Título }\end{array}$ \\
\hline
\end{tabular}


Agradeço a FAPESP pelo apoio, fundamental para realização desta pesquisa. Agradeço a Prof ${ }^{\mathrm{a}}$. Dr ${ }^{\mathrm{a}}$.Ana Lúcia Duarte Lanna, minha orientadora, por ter iluminado esse percurso de forma tão carinhosa e paciente. Agradeço, ainda, os valiosos comentários da minha banca de qualificação e defesa, Prof. Dr. Paulo César G. Marins e Prof ${ }^{\mathrm{a}}$. Dr ${ }^{\mathrm{a}}$. Maria Tereza Duarte Paes. 


\section{RESUMO}

\section{MADUREIRA, Mariana. A construção do Largo das Forras como}

Patrimônio - Tiradentes/MG. Dissertação - Faculdade de Arquitetura e Urbanismo, Universidade de São Paulo, São Paulo, 2011.

O Largo das Forras em Tiradentes (MG) é considerado um espaço de memória, um patrimônio nacional. Interessa a essa pesquisa investigar os motivos que levaram o Largo a ser considerado patrimônio (patrimônio por quê?), os atores que o construíram e se apropriaram dele (patrimônio de quem?) e os valores que representava naquele momento, bem como compreender a evolução dessa ocupação, apropriação e valoração até os dias de hoje. A problemática central a construção do espaço como patrimônio, além das discussões sobre patrimonialização, no contexto de Tiradentes, demandará reflexões acerca da turistificação, isto é, da apropriação do espaço pela atividade turística. $\mathrm{O}$ intuito é debater os valores que norteiam nossas escolhas e como os bens e os lugares que um determinado grupo define como patrimônio são ressignificados ao serem apropriados por seus herdeiros.

Palavras-chave: PATRIMÔNIO; VALORES; TURISMO; TIRADENTES (MG) 


\section{ABSTRACT}

MADUREIRA, Mariana. The construction of Largo das Forras as a Heritage - Tiradentes/MG. Dissertation - Faculdade de Arquitetura e Urbanismo, Universidade de São Paulo, São Paulo, 2011.

Largo das Forras Square in Tiradentes (Minas Gerais, Brazil) is considered a national heritage. This study investigates the reasons why this space is considered cultural patrimony (why heritage?), the actors who built it and got hold of it (whose heritage?) and the values it represented when the policy of safeguard was made - as well as understanding the evolution of its occupation, meanings and valuation until nowadays. The central problem - the construction of the place as a memory site, besides discussing patrimony in the context of Tiradentes' territory, will require thinking the role of tourism in the transformation process. The main objective is discussing the values that guide our choices and see how the goods and places that a specific group defined as heritage are reinterpreted and changed as the legacy is appropriated by successors.

Keywords: HERITAGE; VALUES; TOURISM; TIRADENTES (MG) 


\section{LISTA DE ILUSTRAÇÕES}

\section{Fotos:}

Foto 01: Largo das Forras (2010) _ 25

Foto 02: Panorama da cidade [1920]

Foto 03: Monumento Tiradentes [ 1900]

Foto 04: Casa do Bispo em Mariana (2004) _ 39

Foto 05: Grande Hotel de Ouro Preto (2009)

Foto 06: Pousada Dom Quixote em Tiradentes (2010) __ 41

Foto 07: Casa de Sylvia Nabuco em Tiradentes [2007] ___ 41

Foto 08: Capela de Bom Jesus da Pobreza [1940] __ 50

Foto 09: Novo busto de Tiradentes (1932) __ 55

Foto 10: Largo das Forras com o Busto [1940] _ 55

Foto 11: Monumento Tiradentes (2010)

Foto 12: Busto de Tiradentes guardado na Biblioteca (2010) __ 55

Foto 13: Largo das Forras, vista para atual sobrado da prefeitura [Ca. 1940] __ 56

Foto 14: Monumento e casa de Lourenço Campos [Ca.1960] __ 58

Foto 15: Banco Bamerindus (1980) __ 63

Foto 16: Prataria (1980) __ 63

Foto 17: Largo das Forras: Situação e Proposta [1980] ___ 67

Foto 18: Posto de Gasolina [1980] __ 79

Foto 19: Restaurante Sapore de Itália e Magno Móveis (2010) _ 79

Foto 20: Turistas no Largo das Forras (2010) __ 85

Foto 21: Largo dos Forras - um espaço de consumo (2010) _ 97

Foto 22: Semana Santa em Tiradentes de Tarsila do Amaral (1924) __ 111

Foto 23: Carnaval no Largo das Forras [2000] __ 114

Foto 24: Carnaval em Tiradentes (1950) _ 114

Foto 25: Dever de casa no Largo das Forras (2010) _ 123

Foto 26: Largo das Forras - recorte da paisagem (2010) __ 138

Mapas, Croquis, Plantas, Esquemas e Gráficos:

Figura 01: Perímetro Urbano Tombado ___ 32

Figura 02: Largo das Forras - Vazios no início do séc. XX

Figura 03: Evolução da Ocupação do Território Tiradentino - séc XVIII ao XXI ___ 51

Figura 04: Mapa de Barreiras e Convexidade ___ 61

Figura 05 - Idade dos edifícios do Largo das Forras _ 74

Figura 06: Planta de Reforma do Largo das Forras [1980] __ 78

Figura 07: Zoneamento da Área de Proteção ___ 80

Figura 08: Atuais usos dos edifícios do Largo das Forras ___ 99

Figura 09: Resultados da Pesquisa de Araújo (2006) __ 130

Figura 10: Propriedade dos imóveis do Largo das Forras (2010) ___ 133 


\section{LISTA DE SIGLAS E ABREVIATURAS}

BID - Banco Interamericano de Desenvolvimento

DPHAN - Departamento do Patrimônio Histórico e Artístico Nacional

ET - Extra-tiradentino

FRMFA - Fundação Rodrigo Melo Franco de Andrade

IBPC - Instituto Brasileiro do Patrimônio Cultural

ICCROM - International Centre for the Study of the Preservation and Restoration of Cultural

Property

ICOMOS - International Council on Monuments and Sites

IHGT - Instituto Histórico e Geográfico de Tiradentes

IPHAN - Instituto do Patrimônio Histórico e Artístico Nacional

MTUR - Ministério do Turismo

PUC - Pontifícia Universidade Católica de Minas Gerais

SAT - Sociedade Amigos de Tiradentes

SPHAN - Serviço do Patrimônio Histórico e Artístico Nacional

STJ - Supremo Tribunal de Justiça

UFMG - Universidade Federal de Minas Gerais

UFOP - Universidade Federal de Ouro Preto

UFRJ - Universidade Federal do Rio de Janeiro

UNESCO - United Nations Educational Scientific and Cultural Organization

USP - Universidade de São Paulo 


\section{SUMÁRIO}

INTRODUÇÃ

1 - A CONSTRUÇÃO DE UM LUGAR DE MEMÓRIA .............................................................................25

1.1 O TOMBAMENTO

1.2 AS ORIGENS DO LARGO E SUA DESCONSTRUÇÃO__ 47

1.3 A GESTÃO DO NOVO LUGAR — 64

2 - A TRANSFORMAÇÃO DO LUGAR DE MEMÓRIA EM TERRITÓRIO TURÍSTICO....................... 85

2.1 APORTAM NOVOS ATORES: OS ETS, AS INSTITUIÇÕES E OS TURISTAS ___ 92

2.2 A CRIAÇÃO DOS FESTIVAIS E A IMAGEM DA CIDADE __ 107

2.3 UMA QUESTÃO DE VALOR: O LARGO COMO ESPAÇO LIMINAR _ 122

CONCLUSÃO - O LARGO DAS FORRAS HOJE ..................................................................................... 138

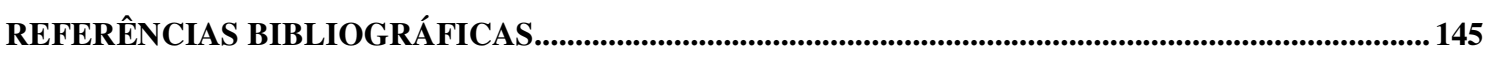




\section{INTRODUÇÃO}

Alois Riegl revolucionou as discussões sobre patrimônio no início do século XX, quando, pela primeira vez, tirou do objeto a denominação de patrimônio como conceito inerente para transferir ao sujeito o poder de atribuição do rótulo "patrimônio" a um objeto, que sem sua apreciação (do sujeito) não possui valor nenhum em si.

De lá pra cá os estudos sobre axiologia e reflexões sobre os valores possíveis (conciliáveis ou não) tem expandido e evoluído. Nos seus primórdios, restrito a objetos da elite, o patrimônio hoje atinge todas as classes e abrange também o intangível - patrimônio imaterial. Muito se discute sobre a validade e a viabilidade dessa expansão do conceito, com preocupações, sobretudo, de como legitimá-la e geri-la. A única questão que resta indubitável, entretanto, é que "patrimônio" é uma denominação simbólica construída por pessoas para valorizar objetos com diferentes propósitos.

O Largo das Forras em Tiradentes, objeto de estudo desta dissertação, é considerado um espaço de memória, um patrimônio nacional. Interessa a essa pesquisa investigar os motivos que levaram o Largo a ser considerado patrimônio (patrimônio por quê?), os atores que o construíram e se apropriaram dele (patrimônio de quem?) e os valores que representava naquele momento, bem como compreender a evolução dessa ocupação, apropriação e valoração até os dias de hoje.

O Largo das Forras foi escolhido dentre tantos outros espaços considerados patrimônios pela curiosa denominação de lugar de memória dada a um espaço recente, construído em sua maior parte na segunda metade do século XX, como detalharemos neste 
trabalho. Se não a as edificações do período colonial, o que é que torna esse espaço digno da denominação de patrimônio cultural?

A problemática central - a construção do espaço como patrimônio, além das discussões sobre patrimonialização, no contexto de Tiradentes, demandará reflexões acerca da turistificação, isto é, da apropriação do espaço pela atividade turística. Tiradentes é um destino indutor do turismo mineiro e do turismo nacional ${ }^{1}$ e recebe, atualmente, milhares de turistas ao ano, sobretudo durante os Festivais de Cinema e Gastronomia. Qual seria, então, a relação entre a turistificação e a patrimonialização do espaço em Tiradentes e no Largo?

Na tentativa de compreender o atual espaço-memória "Largo das Forras", portanto, busca-se analisar as transformações ocorridas no espaço nos últimos anos, sobretudo aquelas causadas pelo turismo, ressaltando-se a importância da atividade para configuração da memória e da paisagem.

Outro importante ponto de discussão é a relação entre a preservação do espaço memória e a transformação sócio-cultural e econômica do lugar. O patrimônio teve a intenção de preservar as formas (e até que ponto houve sucesso?), mas como ficaram significado e função? Refuncionalização, enobrecimento? O que caracteriza a transformação desse espaço residencial e residual de 1938 (ano marco, como será apresentado) para o atual espaço de consumo e lazer?

O objetivo dessa dissertação é, portanto, discutir a criação do espaço de memória contextualizando o processo de construção, ou seja, quem foram os atores, os paradigmas e as

\footnotetext{
${ }^{1}$ Tiradentes está entre os 21 destinos prioritários para o governo de Minas Gerais e entre os 65 prioritários em esfera federal. Os destinos indutores foram escolhidos como o centro de pólos ou circuitos de atratividade para o turismo. Esses destinos recebem prioritariamente os projetos e investimentos para desenvolvimento do setor. Essa política (Plano de Turismo 2007-2010 Mtur) visa estruturar esses centros para funcionarem como âncora do desenvolvimento regional.
} 
motivações de cada período. Em paralelo vão sendo debatidos os efeitos dessas transformações nas formas, funções, estruturas e processos ${ }^{2}$.

As formas urbanas são a base sobre a qual a vida cotidiana transcorre, e elas se moldam e se transformam a partir desse cotidiano. Na paisagem estão impressas não apenas nossas heranças culturais, mas nossas escolhas, passadas e presentes, de continuidade ou ruptura, de resgate ou esquecimento. O que foi mantido? O que foi "resgatado" ou mesmo inventado? O que foi apagado da paisagem do Largo das Forras? Essas são algumas das questões que essa pesquisa pretendeu explorar.

O foco da presente pesquisa é o Largo das Forras aqui abordado individualmente e em seu contexto, que ora compreende a totalidade do centro histórico, ora todo município de Tiradentes, as Minas Gerais, ou mesmo o Brasil, dependendo da discussão pretendida.

Este trabalho baseou-se no estudo das publicações existentes sobre a cidade de Tiradentes, pesquisa nos acervos do Arquivo Municipal, do IPHAN local, no Inventário de Oferta Turística da cidade, Biblioteca Municipal, hemeroteca da PUC Minas, biblioteca da UFMG, USP, UFRJ, sites da internet, entre outras fontes. Foi encontrada grande dificuldade na consulta in loco na cidade, pois a Biblioteca do Museu Padre Toledo ficou fechada para reforma durante quase todo o ano de 2010, os arquivos da Câmara Municipal ${ }^{3}$ estão em fase de catalogação, não podendo ser consultados, e a Biblioteca Municipal possui apenas o livro de Olinto dos Santos Filho em se tratando de história local. No sistema online da PUC Minas há registro de recortes de jornais, mas na consulta física constata-se que alguns se perderam,

\footnotetext{
${ }^{2}$ Santos (1985:50) divide os objetos em 4 aspectos para que possamos compreendê-los e analisa-los. De forma generalizada podemos dizer que a forma é a parte visível de um determinado objeto. A função é a atividade ou o papel desempenhado pelo objeto no mundo (ele serve para quê?). A estrutura é a relação das partes do objeto com ele mesmo, do objeto com os demais objetos e com o entorno. Segundo o autor "estrutura implica a interrelação de todas as partes de um todo, o modo de organização ou construção", ou seja, exige uma análise da estrutura demográfica, de classe, de consumo, etc. Por último, o processo implica na história do objeto, isto é, na formação - qual tipo de percurso e encalços formou a atual forma do objeto. O processo é o devir natural que constrói, desconstrói e reconstrói o objeto.

${ }^{3}$ Fernanda Lima (2008:252) encontrou problemas semelhantes na Câmara de Tiradentes: "Vale ressaltar que são poucas as legislações existentes na nova gestão, tendo em vista que muitos documentos se perderam ou foram incinerados durante mudança de gestão".
} 
ou foram armazenados incorretamente impossibilitando a localização. Por esse motivo foram encontradas algumas poucas notícias, mas sem grande relevância. A UFRJ não disponibiliza suas teses online, o que obrigou um deslocamento interestadual para consulta de seu acervo. Os artigos disponíveis na internet muitas vezes não oferecem referências completas para identificação de seu ano, local e forma de publicação.

Apesar das dificuldades encontradas para consulta de bibliografia específica sobre Tiradentes, após pesquisa exaustiva foram encontrados aproximadamente 30 estudos sobre temas correlatos a esta pesquisa envolvendo o município. Dentre eles tiveram especial relevância a dissertação de Márcia Araújo (2004) - uma pesquisa extensa com 142 famílias (o que abrange 524 pessoas) investigando a relação delas com o patrimônio de Tiradentes e com o turismo em três diferentes âmbitos: residência, trabalho e lazer; o trabalho de Souza e Phillipo (2004) - que apresenta na íntegra as 05 entrevistas consideradas pelas autoras as mais relevantes, dentre as 100 realizadas, com pessoas da comunidade; o livro de Lélia Frota (1993) - apresenta a história de forma quase poética e explicita o papel da Fundação Rodrigo Melo Franco de Andrade na recuperação de boa parte do acervo arquitetônico na década de 1980; a monografia de Marina Salgado (2007) - discorre sobre as novas formas urbanas no centro de Tiradentes; a dissertação de Hélcio Campos (2006) - sobre as mudanças recentes na configuração urbana da cidade, defendendo a hipótese de que tenha ocorrido uma "gentrificação incompleta"; a dissertação de Gustavo Zoline (2007) nessa mesma linha, descrevendo as transformações como uma "gentrificação intermitente"; as dissertações de Cerqueira (2006) e Lima (2008) que comparam as cidades de Tiradentes e Diamantina em termos de políticas e de institucionalização do patrimônio cultural; o artigo de Everaldo Costa (2008) que defende que em Tiradentes houve uma "banalização pela cenarização"; o artigo de Camurça e Giovannni Junior (2003) e a dissertação de Giovaninni Jr (2002) - que discorrem sobre os eventos (sobretudo a Semana Santa) em Tiradentes; o artigo de Bolson e Ferreira 
(2006) - que apresenta trechos de entrevistas realizadas em 2005 com o então secretário de turismo, o pároco local, artesãos, lojistas e funcionários de hotéis, mostrando a impressão que cada um deles tem da atividade turística no local - bastante divergentes; e a monografia (2005), o artigo (2006) e a dissertação (2007) de Tadine Jr, que buscam explicar o desenvolvimento da cidade através de suas investidas em citymarketing.

Foram também de fundamental importância para esse trabalho o Plano de Organização Espacial e Preservação do Centro Histórico feito pela Fundação João Pinheiro (1980), cujo principal objetivo era criar condições de desenvolvimento econômico à partir da urbanização e da utilização do patrimônio para fins turísticos e o Projeto Piloto elaborado pelo Instituto Brasileiro de Patrimônio Cultural - IBPC (1997) que contou com o detalhamento dos imóveis do centro urbano (finalmente registrados individualmente, mas não em sua totalidade) e com a criação de diretrizes de gestão do espaço urbano de acordo com zonas estabelecidas. Esse zoneamento teve como intuito diferenciar as áreas que necessitam de maior cuidado e restrição das áreas novas, distinguir as partes intermediárias (passagem do centro histórico para os novos bairros) e dirigir também as intervenções em áreas que, apesar de novas, influenciam na paisagem antiga por sua localização - principalmente as encostas.

Foram feitas seis visitas de campo ao longo de 2009 e 2010 alternando períodos de baixa estação para o turismo e eventos de alta visitação. Durante essas visitas registrou-se (em textos e imagens) as formas e os usos encontrados no Largo e foram realizadas diversas entrevistas informais, praticamente conversas casuais, com turistas, moradores da cidade e funcionários dos empreendimentos do Largo. Foram realizadas entrevistas formais, abertas e dirigidas com alguns atores locais apontados em trabalhos consultados e nas conversas informais com moradores como as pessoas mais indicadas - nas palavras do garçom de um dos empreendimentos do Largo "quem sabe falar sobre patrimônio e essas coisas". Foram realizadas 2 entrevistas (com espaço de um ano entre elas) com Olinto dos Santos Filho 
(dirigente do IPHAN local, tiradentino, historiador e autor do livro Guia da Cidade de Tiradentes), 2 entrevista com Rogério Almeida (tiradentino, historiador, vereador e Coordenador do Centro de Cultura e Patrimônio, Memória e Cidadania de Tiradentes) e uma entrevista com Cínthia Campos (tiradentina, neta de Lourenço Campos, historiadora e responsável pelo Departamento Municipal de Cultura) e Karine Barbosa (neta de Francisco Barbosa, historiadora, funcionária do gabinete da Prefeitura Municipal).

A estrutura de apresentação dessa dissertação pretende apresentar os resultados dessa pesquisa da seguinte forma:

No capítulo 1 Construção de um Lugar de Memória é apresentado o contexto e o paradigma de preservação vigentes no tombamento de 1938 - um marco para a construção do Largo das Forras como patrimônio, buscando ressaltar o que foi tombado, por quem e com quais objetivos.

Como em um flashback, apresentamos a situação anterior ao tombamento, mostrando como o Largo foi construído ao longo do século XVII e XVIII. Essa imagem construída em dois séculos começa, sobretudo depois de 1938, a ser desconstruída para abrigar um novo conjunto de imagens e valores incompatíveis com os presentes até então. Esse processo de desconstrução dura algumas décadas e culmina na criação de um espaço ideal para as transformações pós-1970.

A discussão sobre a gestão do patrimônio ao longo de todo esse processo de construção do lugar de memória são fundamentais para a compreensão das escolhas que deram origem ao lugar que existe hoje.

O capítulo 2 A transformação do Lugar de Memória em Território Turístico trata do processo de formação do território turístico iniciado a partir de 1970. O foco desse capítulo é a discussão dos novos atores, as motivações dos diferentes grupos e o contexto das 
transformações. Ele aborda a participação de cada um dos principais responsáveis pelas grandes transformações sofridas nos últimos 40 anos: os ETs, as instituições, o turismo e os eventos. É objeto dessa discussão, sobretudo, a relação entre esses atores e o Largo incluindo os conflitos no uso;

Finalmente, em O Largo das Forras Hoje tratamos do espaço tal qual podemos visitar atualmente. O que é, o que significa e quem se apropria dele.

Considerando que "apropriar-se de um espaço é reconstruir sua lógica temporal, é reativar um mecanismo de articulação entre tempo e espaço, diferente do anterior" (NICOLAS, 1998:86), ao nos apropriarmos do objeto Largo das Forras, deixamos a análise sincrônica de lado para adotar um pensamento que passeia entre presente, passado recente e passado remoto em busca das repostas às questões colocadas. 


\section{1 - A CONSTRUÇÃO DE UM LUGAR DE MEMÓRIA}

"Toda paisagem apresenta-se, de início, como uma imensa desordem que nos deixa livres para escolhermos o sentido que preferimos lhe atribuir".(LEVI-STRAUSS, 2010:54)

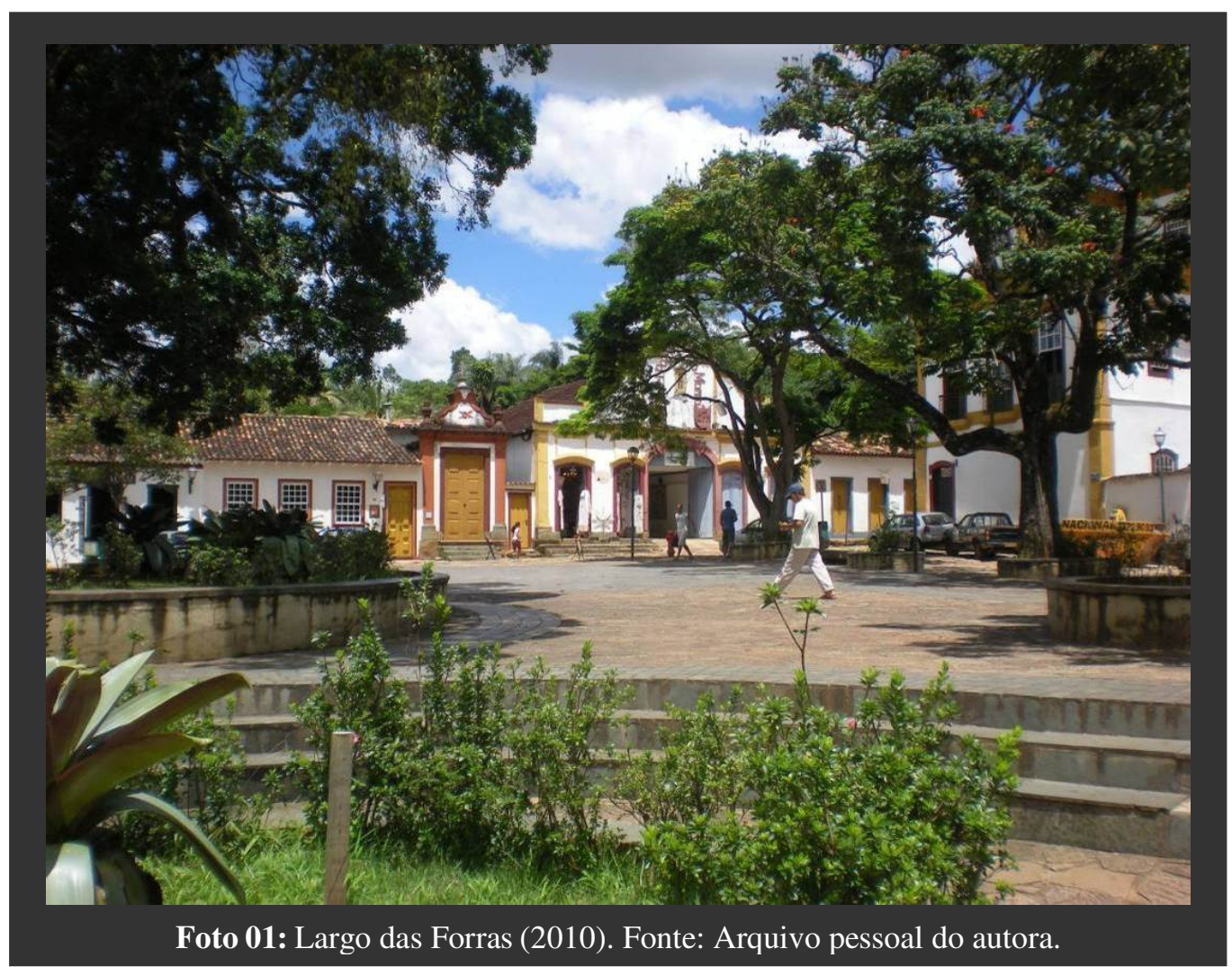

O Largo das Forras é um dos espaços de maior fluxo de pessoas na cidade de Tiradentes e se apresenta como um lugar repleto de signos que instigam uma interpretação. Sua denominação de patrimônio provoca o questionamento de como esse espaço veio a ser construído como um lugar de memória.

Antes de entrarmos nessa discussão, contudo, é preciso compreender o que é e como se constrói um lugar ou lugar de memória.

Segundo a pesquisa de Adriana Leite (1998), a primeira acepção registrada de lugar vem de Aristóteles que o definiu como o limite que circunda o corpo. Pouco mais tarde, 
Descartes complementou essa definição argumentando que, além de delimitar o corpo, o lugar deveria ser também definido em relação a posição de outros corpos (RIBEIRO, 1993).

$\mathrm{Na}$ atualidade as concepções de lugar se dividem basicamente em duas correntes: A primeira é a da geografia humanística, que se caracteriza, sobretudo, pela valorização das relações de afetividade desenvolvidas pelos indivíduos em relação ao seu ambiente. "Para tanto houve um apelo às filosofias do significado - fenomenologia, existencialismo, idealismo e hermenêutica - que em essência encontram na subjetividade humana as interpretações para suas atitudes perante o mundo" (LEITE, 1998:09) tendo como principais contribuições os trabalhos de Mello, Holzer, Edward Relph, Yi-Fu Tuan, Anne Buttimer e J. N. Entrikin. E a segunda é a concepção de lugar segundo a dialética marxista, para a qual "o lugar é considerado tanto como produto de uma dinâmica que é única, ou seja, resultante de características históricas e culturais intrínsecas ao seu processo de formação, quanto como uma expressão da globalidade". Entendemos que essas duas concepções além de não serem excludentes, podem ser complementares.

Para Tuan (1975:152) o lugar “é um centro de significados construído pela experiência". Nesse mesmo sentido Relph (1979:03) afirma que lugar "significa muito mais que o sentido geográfico de localização. Não se refere a objetos e atributos das localizações, mas a tipos de experiência e envolvimento com o mundo, a necessidade de raízes e segurança”.

Leite (1998:17) afirma, reforçando a concepção segundo a dialética marxista, que “o lugar surge como produto de uma ambiguidade que se estende a todas as relações sociais que envolvem o homem e o meio - é o singular (o fragmento) e é também o global (universal) que o determinam".

O lugar é essencialmente uma produção humana, pois é produto da relação entre espaço e sociedade, o que abrange criação, estabelecimento de vínculos, identidades e 
apropriações para vida (CARLOS, 1996:28). Ana Fani Carlos (1994:192) afirma, ainda, que seria o lugar "o espaço passível de ser sentido, pensado, apropriado e vivido através do corpo".

Considerando que o lugar é o espaço apreendido pelos 6 sentidos, sendo o sexto a memória, "lugar" e "lugar de memória" podem ser considerados sinônimos. Para Gastal (2002:77) os lugares de memória são espaços onde "as diferentes memórias estão presentes no tecido urbano, transformando espaços em lugares únicos e com forte apelo afetivo para quem neles vive ou para quem os visitam". O acumulo de memórias seria, nesse caso, o responsável pela formação do lugar de memória - um palimpsesto de objetos e técnicas diferentemente datados.

Segundo Maziviero (2008:13) a memória é "um dos elementos fundamentais da condição humana, cujo pré-requisito existencial, a despeito de sua característica fluida, é a materialidade". Por isso os lugares se tornam tão importantes para a concretização das lembranças e criação de uma identidade. A arquitetura, os monumentos, o patrimônio tem sua importância na criação desse lugar de memória e identidade, como explicita Arantes (1997:288):

Os marcos culturais de pedra e cal, antigas estruturas arquitetônicas em paisagens urbanas (...) celebram realizações políticas e estéticas, sempre sujeitas a reelaboração pela cultura vernacular na luta pela legitimação dos interesses práticos, valores estéticos e visões de mundo. Eles são, além disso, resultado de processos que transformam "espaços" em "lugares", isto é, em sítios habitados por pessoas que vivem de forma determinada e que os consideram como algo que lhes pertence ou, no mínimo, lhes dizem respeito.

Andreas Huyssen (2000:18) afirma que nossas memórias são sempre seleções e que, com o tempo, podem ir sofrendo adições e transformações involuntárias. "Freud já nos ensinou que a memória e o esquecimento estão indissolúvel e mutuamente ligados, que a memória é apenas uma outra forma de esquecimento e que esquecimento é uma forma de memória escondida". 
A memória, segundo Nora (1988:09) "se enraíza no concreto, no espaço, no gesto, na imagem, no objeto". Pierre Nora (op cit) acredita que da fusão da história (distante sem a memória) ${ }^{4}$ e da memória (que tem na contemporaneidade a necessidade se situar no tempo através da história) surjam os denominados pelo autor de "lugares de memória", como um meio de acesso às lembranças através da ritualização dessa história-memória. Esses lugares específicos seriam a forma das sociedades contemporâneas lidarem com o passado, respeitando-o (seja ele real ou imaginário) e buscando pertencimento a um grupo e a um espaço - seu lugar de memória. Nesse trabalho usamos o termo com ênfase na sua propriedade de "espaço para recordar", ou seja, de símbolo criado e/ou mantido com intuito de representar a história coletiva, a memória e a identidade de um grupo.

\subsection{O TOMBAMENTO}

O Largo das Forras, juntamente com todo o centro histórico de Tiradentes, foi designado patrimônio nacional em 1938 pelo Serviço do Patrimônio Histórico e Artístico Nacional (SPHAN, hoje IPHAN). Nesse momento a política de preservação do patrimônio brasileiro se encontrava em construção, tendo o próprio SPHAN sido criado há apenas um ano.

\footnotetext{
4 Pierre Nora (1988) faz uma distinção entre memória e história, afirmando que "a memória é o absoluto e a história o relativo". Acredita que essa diferença não seja universalmente percebida, pois vivemos hoje um momento de afastamento. "Nós vivíamos na intimidade de uma memória, para só viver [hoje] sob o olhar de uma história reconstituída."
} 


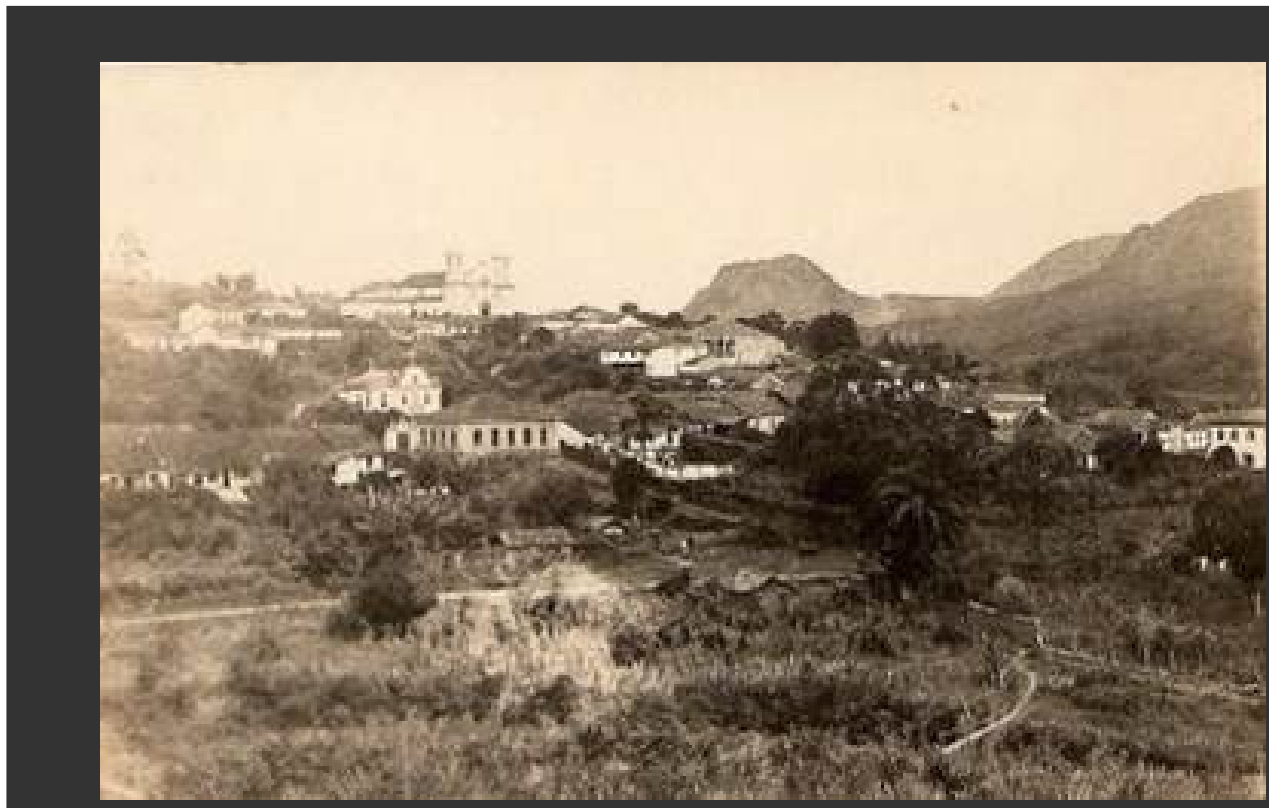

Foto 02: Panorama da cidade [1920]. Fonte: Instituto Histórico Geográfico.

Dentre os precursores do patrimônio brasileiro, pode-se destacar a atuação dos modernistas Mário de Andrade, Rodrigo Melo Franco de Andrade e Gustavo Campanema.

No momento em que a cidade foi tombada Rodrigo Melo Franco de Andrade era o presidente do SPHAN. Segundo Frota (2005:55)

O escolhido esteve à altura da unanimidade de sua indicação. Abriu mão das atividades literárias e jornalísticas, e se dedicou por mais de 30 anos - 1936 a 1967 - à administração dos bens culturais. Soube cercar-se de uma equipe extraordinária, com a qual trabalhou em colegiado, num regime de total confiança. Lúcio Costa, Carlos Drummond de Andrade, Sérgio Buarque de Holanda, Manuel Bandeira, Oscar Niemayer, Joaquim Cardoso, Alcides Rocha Miranda, Gilberto Freire, Prudente de Morais Neto, Luís Camilo, Afonso Arinos, Heloísa Alberto Torres, o próprio Mário de Andrade, Paulo Thedim Barreto, José Reis, Gastão Cruls, Luis Jardim estão entre os inúmeros colaboradores do SPHAN.

Sua contribuição para a preservação do acervo de Tiradentes será reconhecida mais tarde, quando uma fundação de proteção ao patrimônio é criada com seu nome através do apoio de Israel Pinheiro, então governador do Estado. 
Uma das principais motivações desse grupo de intelectuais, que segundo Fonseca (1997:111) caracterizavam "a função social do intelectual como mediador entre os interesses populares e o Estado", era a criação de uma identidade nacional brasileira. Nesse contexto a arquitetura colonial tinha um papel primordial, pois representava a herança arquitetônica mais antiga e, apesar da grande influência do barroco português, essa arquitetura possuia feições próprias criadas pela adaptação de um estilo europeu a um novo espaço com clima, altitude, solo e, sobretudo, matérias primas e necessidades diferentes.

Lopes, Velosso e Pesavento (2006:297) chamam atenção para a diferença entre a construção da nação brasileira e francesa, já que houve "a desqualificação intencional do barroco na França e, ao contrário, sua supervalorização, na invenção do passado nacional para o Brasil."

Segundo Fonseca (1997:59), desde a proclamação da Republica, mas mais intensamente no governo Vargas, percebe-se que "a noção de patrimônio contribui para objetivar, tornar visível e real, essa identidade ideal que é a nação [...] A necessidade de proteger esse patrimônio comum reforça a coesão nacional", visando ainda "reforçar a noção de cidadania, na medida em que são identificados, no espaço público, bens que não são de posse privada, mas propriedade de todos os cidadãos, a serem utilizados em nome do gestor público".

Minas Gerais, com toda sua herança setecentista, foi o laboratório perfeito para a incipiente gestão patrimonial no país, tendo Ouro Preto - seu maior expoente - sido decretada patrimônio nacional antes mesmo da criação do órgão responsável pelo patrimônio - SPHAN.

O interesse dos modernistas pelas cidades coloniais mineiras, dentre elas Tiradentes, foi despertado quase 20 anos antes do tombamento se concretizar.

Em 1919, Mário de Andrade visitou Tiradentes, retornando em 1924 acompanhado de Tarsila do Amaral, do escritor franco-suíço Blaise Cendras, Oswald de Andrade e outras significativas personagens daquela época. Uma 
caravana que excursionou pelas cidades do ouro inspirando inúmeras e pertinentes referências a Tiradentes em diversos textos posteriormente publicados. (COSTA, 2007:12)

Impressionado, Mário de Andrade escreve a Manuel Bandeira, que iniciaria uma viagem por Minas, em 1928: “Acho imprescindível vocês irem também a São José del Rei que fica pertinho de São João del Rei. A matriz de lá é magnífica por dentro e das mais luxuosas. O quadro que esconde o altar-mor, o retábulo móvel, é uma obra prima do privitivismo". (ANDRADE, 1956:85 In: FROTA, 2005:71)

Com a criação do órgão em 1937, não só foi regulamentado o tombamento de Ouro Preto de 1933, como foram realizados tombamentos de conjunto em várias outras cidades mineiras em 1938, como São João Del Rey, Diamantina e Mariana, além de nosso estudo de caso - Tiradentes.

Como instrumento para proteção da cidade de Tiradentes em 1938 utilizou-se o tombamento de sítio histórico. Isso significa que os bens imóveis não foram registrados e valorados individualmente, mas em seu conjunto.

Tiradentes, bem como as demais cidades mineiras tombadas no período, passou por um processo de tombamento bastante inovador para o seu tempo - o tombamento de conjunto. Até o início do século XX muita atenção era dada aos grandes monumentos, mas os conjuntos do que John Ruskin (1981) denominou de "arquitetura menor" eram, via de regra, ignorados. Um bom exemplo desse tratamento foi a reforma hausmaniana de Paris, que manteve os grandes monumentos como o Arco do Triunfo e a Catedral de Notre Damme, mas destruiu todo conjunto de casas do centro que, segundo o Barão de Hausmann, impediam a livre circulação e causavam insalubridade à cidade. 


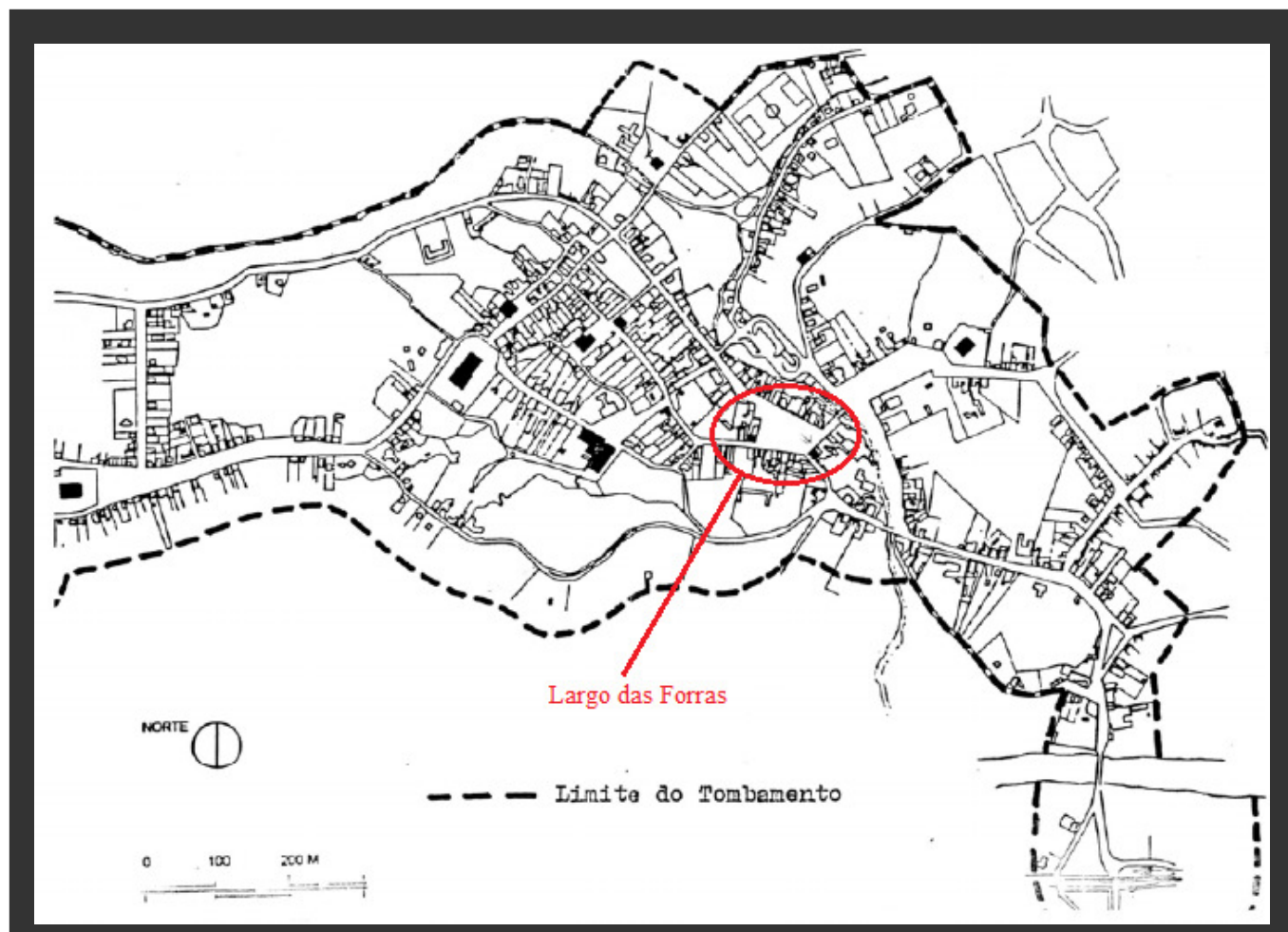

Figura 01: Perímetro Urbano Tombado. Fonte: IBPC (1997) com destaque (Largo) nosso.

Esse tombamento foi registrado no livro de belas artes ${ }^{5}$, o que é bastante coerente com o paradigma de cidade-monumento vigente.

Desde a criação do SPHAN, em 1937, já se apresentava a preocupação com as cidades entendidas enquanto monumentos, com os tombamentos dos primeiros conjuntos urbanos. No entanto, a visão predominante era a que correspondia a cidades que poderiam ser compreendidas como acabadas e concluídas, monumentos a serem preservados em sua feição original, os quais se mantiveram como tal por estarem à margem do processo de desenvolvimento que se processava no país. Cidades estagnadas e esquecidas. (BRITO, 2004:22).

Essa percepção de que uma cidade inteira pudesse ser preservada com os mesmos critérios que se preserva um monumento, fará com que, nesse estágio da tutela patrimonial,

\footnotetext{
${ }^{5}$ O IPHAN adotou como Livros de Registro do Patrimônio Material o Livro de Tombo das Belas Artes (referente aos exemplares de arte erudita nacionais ou estrangeiros), Histórico (artes, documentos, ou qualquer objeto de interesse histórico), das Artes Aplicadas e Arqueológico, Etnográfico e Paisagístico. Recentemente, com a criação de critérios de registro do Patrimônio Imaterial, foram criados os Livros de Registro dos Saberes (saber-fazer), das Celebrações (rituais e festas), das Formas de Expressão (artes) e dos Lugares.
} 
não existam ferramentas de gestão específicas para espaços urbanos e políticas que levem em conta as peculiares necessidades de uso e expansão das cidades, criando-se (apenas teoricamente) um congelamento da cidade tal qual se encontrava no momento do tombamento.

Muitas vezes ocorriam adaptações da paisagem visando atingir os critérios estilísticos e estéticos que se buscava "preservar":

Se esta vertente da arte brasileira [arquitetura barroca colonial] era hipervalorizada pelos intelectuais modernistas, que se ocupavam ainda da renovação das artes no país, as demais manifestações arquitetônicas posteriores eram mal vistas e freqüentemente "corrigidas", como aconteceu várias vezes nas cidades mineiras: edifícios neoclássicos, ecléticos, artnouveau, art-déco eram freqüentemente alterados em suas linhas arquitetônicas para que se adequassem ao modelo predominante de arquitetura nas cidades (DUARTE JR, 2005).

No Largo das Forras essa "purificação do estilo" se deu quatro décadas após o tombamento, não mais objetivando a criação de um modelo homogêneo que representasse a nação (como ocorreu em Ouro Preto e outras cidades mineiras), mas em um processo distinto de valorização estética para fins econômicos (principalmente através do desenvolvimento do turismo) que detalharemos mais adiante.

No caso do tombamento de Tiradentes de 1938, em consonância com a ideologia de seu período (paradigma da cidade-monumento), houve prevalência do valor estético (ou artístico) em detrimento do valor histórico (ou documental).

Riegl (1987) diria que não houve grande prejuízo de um valor frente ao outro, pois o autor afirma que todo objeto histórico (assim como toda foram) tem uma arte própria, e toda arte tem, por sua vez, uma história. Lemaire (1994:12) sustenta que o valor artístico seja o mais importante em um bem patrimonial, pois possui, segundo ele, uma "natureza essencial", enquanto que "o valor histórico ou simbólico, não pertencendo ao objetivo perseguido pelo criador da obra, constituem 'acidentes' devido a fatores que são exteriores a ele, tais como, 
entre outros, a ação de forças naturais, a evolução das mentalidades e das sensibilidades. São, desse modo, de natureza acidental". O mesmo autor afirma ainda que o "papel principal [do patrimônio monumental] é emitir uma mensagem estética e não coordenadas históricas irrepreensíveis".

\section{O que se tombou em 1938, portanto, foi a estética ${ }^{6}$ da paisagem urbana existente} e o etilo arquitetônico colonial - recém definido referência identitária nacional. Pouco se sabe sobre a datação, modificações e reformas, usos, proprietários e história de cada edifício, importando mais, no momento do registro, suas características barrocas para composição do conjunto.

Ocorre, no entanto, que vários imóveis antigos se encontravam em estado lastimável quando ocorreu o tombamento. Havia ruínas, construções que não seguiam o estilo colonial e havia, sobretudo, muitos vazios urbanos.

Se na cidade os vazios eram comuns, no Largo das Forras (então espaço periférico, como apresentaremos mais adiante) as lacunas representavam mais da metade dos espaços disponíveis - que são atualmente ocupados por construções.

\footnotetext{
6 Estética é, frequentemente, confundida com beleza. Segundo Andrew Edgar (2003:44) a beleza "é um termochave na estética, que pode ser usado para se referir à propriedade que faz uma obra de arte (e mesmo objetos naturais) ser digna de contemplação". A estética, por sua vez, seria "uma subdisciplina da filosofia que lida com questões de arte e beleza”.
} 


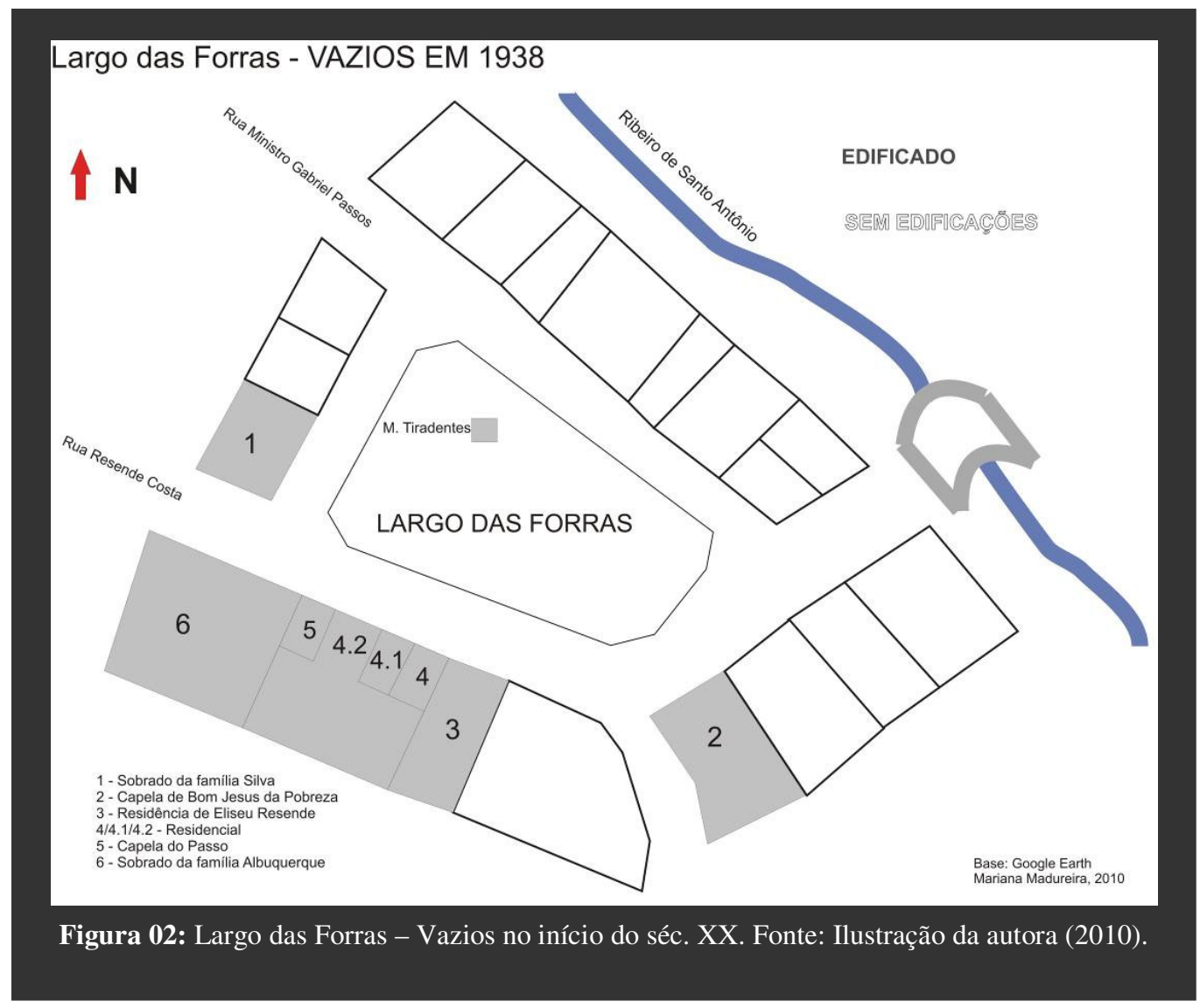

Os vazios podem ser observados na figura 02 e na foto 03 , que mostra o monumento a Tiradentes (1892) no início do século XX. Percebe-se que todo o norte do Largo, às margens do Ribeiro de Santo Antônio, não está ocupado nesse período. No início do século XX também não existiam construções próximas ao sobrado (atual prefeitura) e próximas à ponte de pedra. Segundo o Projeto Piloto do Instituto Brasileiro do Patrimônio Cultural (1997:16) para o sítio histórico de Tiradentes, “(...) frágeis foram as estruturas que consolidaram o núcleo urbano, já que jamais firmou-se como um centro densamente ocupado, havendo a presença marcante de vazios, que acabaram por se tornar uma das principais características da ocupação”. 


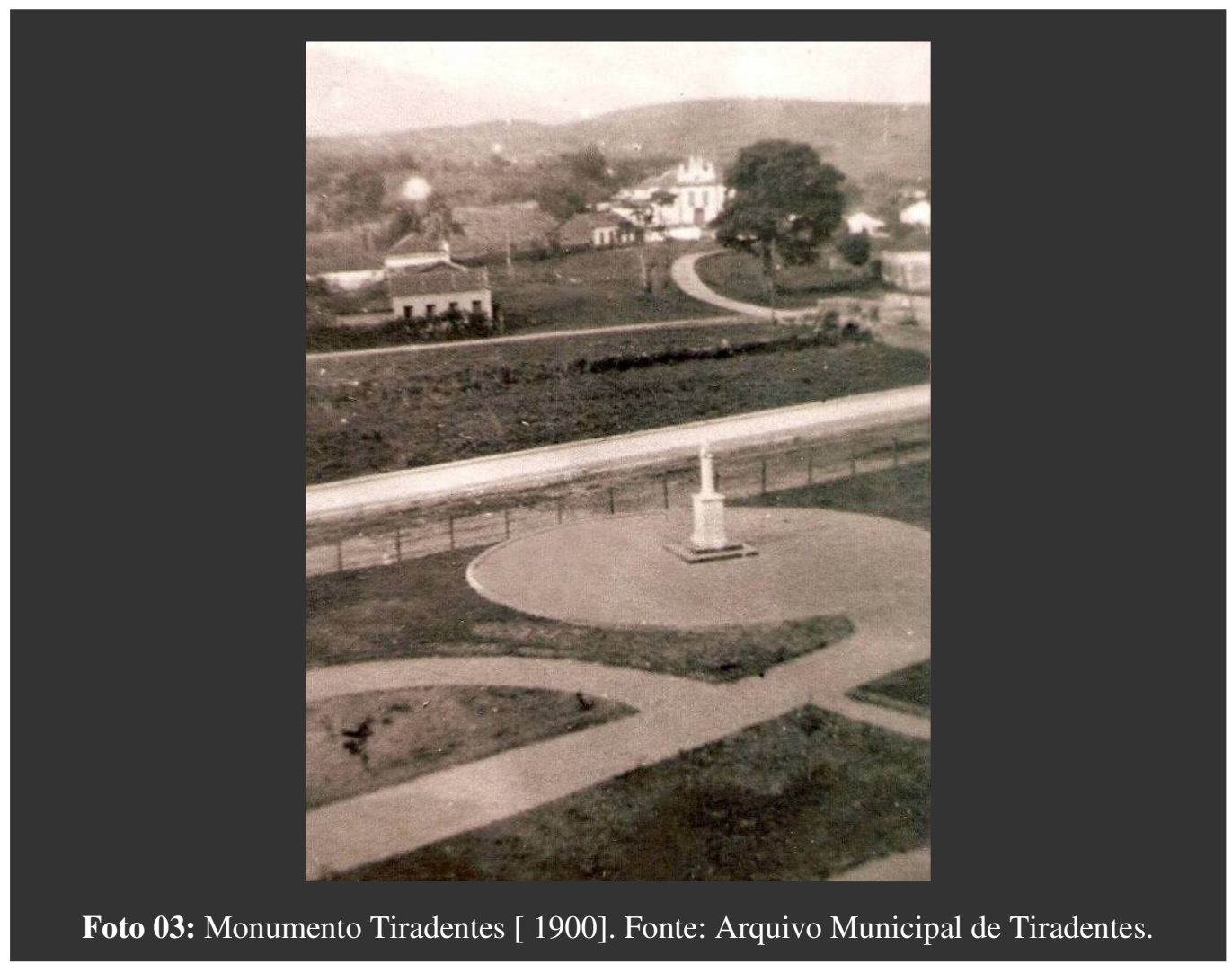

Proceder ao preenchimento de vazios em centros históricos é uma decisão polêmica. No caso do Largo das Forras, houve um incentivo para que os vazios fossem preenchidos logo após o tombamento, como mostra o dossiê de tombamento do Monumento Tiradentes (2007), que cita que o lote norte da praça, "o terreno de 2.400m foi doado a Francisco Araújo Lima que construiu uma curiosa casa, de estilo estranho, por volta de 1940, passando depois, em 1942 a Vicente Trindade Guerra, depois a Eugênio Longatti e Lourenço Campos”.

Atualmente justifica-se a opção por preenchê-los considerando que um vazio urbano significa um desperdício de espaço, uma desnecessária diluição do espaço urbano (tendo em vista os benéficos sócio-ambientais da compactação das cidades ${ }^{7}$ ), uma possibilidade de

\footnotetext{
${ }^{7}$ Vide: ROGERS, Richard. Cidades para um Pequeno Planeta. Ed. Gustavo Gili,: Barcelona, 2001.
} 
especulação imobiliária ou um risco de aproveitamento do espaço residual para fins indesejáveis como assentamentos irregulares e usos marginalizados.

Naquele momento (década de 1940) essas necessidades (e, portanto, possíveis justificativas) não existiam, tendo a doação de terras sido, provavelmente, um incentivo ao desenvolvimento da cidade que passava por um período de baixa movimentação econômica como veremos no capítulo 1.2.

Ao se optar pelo preenchimento de vazios atualmente, a decisão acarreta dúvida mais complexa: preenchê-lo com o quê? Deve-se, nesses casos, optar por uma arquitetura mimética (também conhecida como "estilo patrimônio"), uma arquitetura contemporânea ao momento da intervenção (atual), ou algum meio-termo, como as propostas que mesclam o estilo original (volumetria, formato, posição no lote e elementos estilísticos) com materiais e técnicas contemporâneos?

Exemplos de arquitetura mimética são os mais recorrentes. Trata-se das construções novas que copiam estilos antigos - nesse caso o barroco mineiro do período colonial. São também chamados pejorativamente de "estilo patrimônio" e criticados por criarem um "falso histórico", isto é, induzirem o observador à crença de que aquela arquitetura pertence a um outro período.

Segundo Lia Motta (1987:115), por muitos anos o IPHAN tentou manter a harmonia dos conjuntos através de diretrizes gerais:

Eram exigidos telhados em duas águas, com telha canal, galbo no contrafeito e beiral encachorrado, janelas em guilhotinas com caixilhos, medindo 1,00 por $1,50 \mathrm{~m}$, e cerdura de 0,10 ou $0,12 \mathrm{~m}$, pintura de cor branca nas alvenarias e cor escura nas madeiras. 
Como efeito perverso, contudo, essas regras e fórmulas tornaram "evidente a participação do próprio Patrimônio como promotor do que hoje é, justamente, chamado de ‘estilo patrimônio’ pelos moradores locais [de Ouro Preto]” (MOTTA, op cit).

Para exemplificar as opções por preencher vazios com obras atuais, nada melhor que o Grande Hotel de Ouro Preto. Construído por Oscar Niemayer em 1943, causou grande polêmica por suas curvas modernas e volumetria desproporcional. A justificativa apresentada por Lúcio Costa ao então presidente do SPHAN Rodrigo Melo Franco de Andrade em carta pessoal é, no entanto, digna de nota e reflexão:

Sei, por experiência própria, que a reprodução do estilo das casas de Ouro Preto só é possível, hoje em dia, à custa de muito artifício...teríamos, depois de concluída a obra, ou uma imitação perfeita e o turista desprecavido correria o risco de, à primeira vista, tomar por um dos principais monumentos da cidade uma contrafacção, ou então, fracassada a tentativa, teríamos um arremedo neocolonial em nada em comum com o verdadeiro espírito das velhas construções.

Ora, o projecto de O.N.S. [Oscar Niemayer Soares] tem pelo menos duas coisas em comum com elas: beleza e verdade...não deverá estranhar a vizinhança de outras obras de arte, embora diferentes, porque a boa arquitectura de um determinado período vai sempre bem com a de qualquer período anterior - o que não combina com coisa nenhuma é a falta de arquitectura. (IN: CAVALCANTI, 2006)

A grande dificuldade que se teria, contudo, para manutenção dessa proposta ousada e inovadora de uso dos espaços residuais de centros históricos seria a definição do que é ou não é "boa arquitetura".

Um exemplo de opção por ‘uma terceira via', ou ‘meio-termo', é a Casa do Arcebispo na cidade mineira de Mariana. Em meio a um conjunto histórico os arquitetos Éolo Maia, Jô de Vasconcelos e Sylvio de Podestá optaram por construir uma casa com volumetria idêntica aos sobrados oitocentistas, preenchimento de cheios e vazios idem, cores coloniais e telhados típicos com beirais e cachorros, dentre outros elementos tipológicos da época. Um detalhe importante, contudo, é que os arquitetos optaram por usar materiais e técnicas modernas, substituíram a madeira que emolduraria tradicionalmente as portas e janelas e armaria os 
beirais por barras de metal, recobriram o pátio com vidro e usaram o interior para atender as necessidades do então bispo (1983) Dom Oscar. Avistando a casa do outro lado da praça é difícil distingui-la das demais do conjunto. Ao aproximar-se, contudo, percebe-se suas especificidades. O projeto, como era de se esperar, foi apelidado de "monstro da praça" por uns (a exemplo os estudantes da UFOP) e considerado modelo por outros, como o crítico de arquitetura Eduardo Comas que o elegeu como um dos projetos mais importantes de sua década.

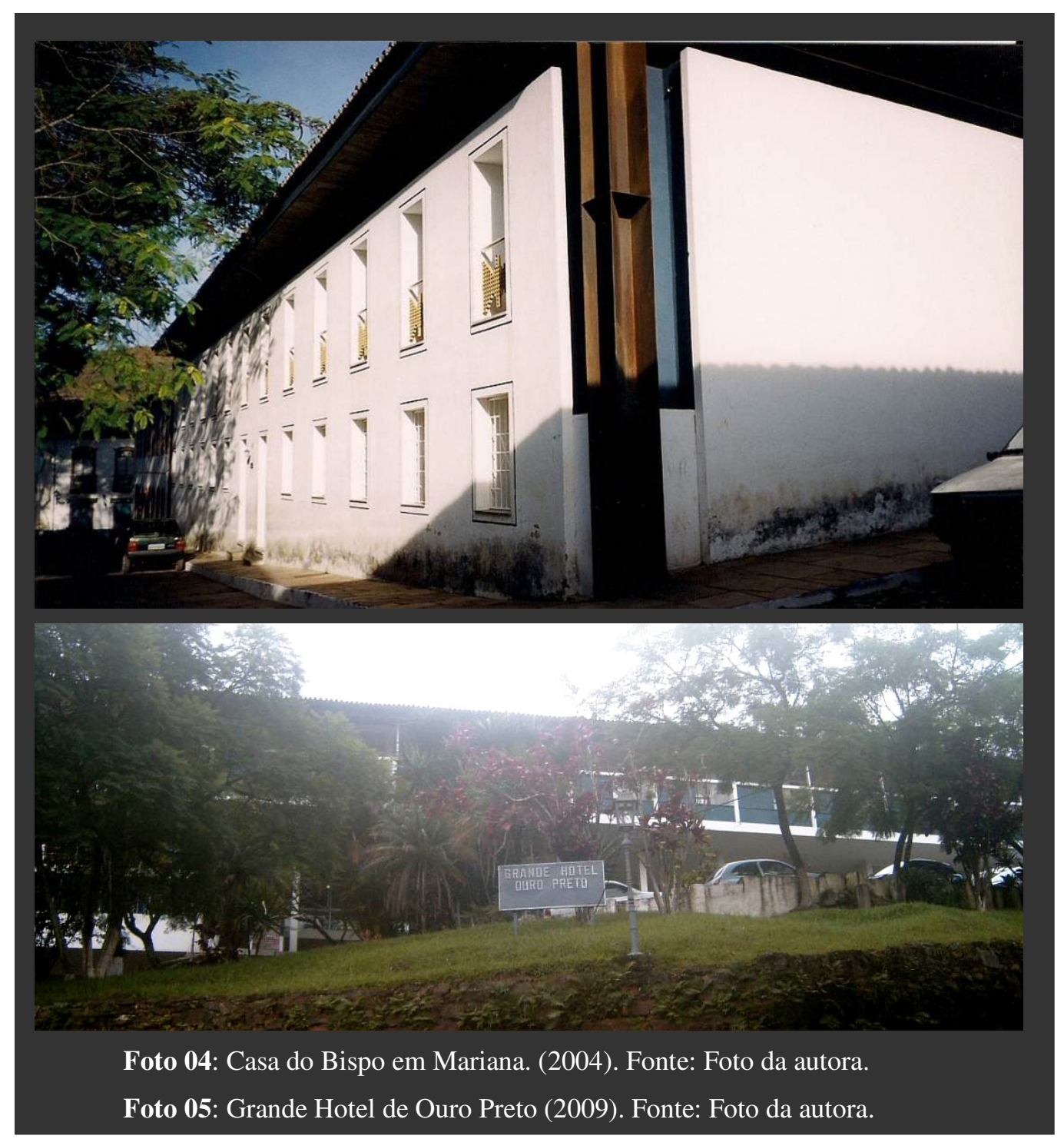


Uma interpretação feita por Meniconi (1998:56) com base em Panne e Bonelli (ambos adeptos da teoria crítica do restauro) explicita o valor desse tipo de intervenção:

A restauração é uma ato crítico, interpretativo, que se expressa diretamente no corpo da obra criticada e usa os mesmos recursos figurativos. Restaurar é reintegrar o valor expressivo da imagem, eliminando tudo aquilo que deturpa e dificulta a leitura de seus valores. Quando a leitura dessa imagem está truncada, ela deve ser completada, com um ato criativo, que estabeleça uma nova unidade, resultando em um diálogo entre o velho e o novo.

Em Tiradentes podemos citar como exemplo de arquitetura mimética a casa da Rua Direita N. 266 (ruiu e foi reconstruída). No Largo das Forras, o Bêta da Prata, o Sobrado Barbosa, a Pousada Mãe D’Água, o Empório Valnice, entre outros.

Como inserção do "novo" no centro antigo de Tiradentes, a Pousada Dom Quixote é um bom exemplo. Já no Largo das Forras não encontramos esse tipo de intervenção.

E, por último, como "terceira via", isto é, um novo com referência forte ao antigo, a casa de Sylvia Nabuco - filha de Maria do Carmo Nabuco presidente da Fundação Rodrigo Melo Franco de Andrade. O projeto foi realizado pelo arquiteto Alcides da Rocha Miranda para ruína de uma casa na Rua Direita em 1987, na qual "a construção acompanha a declividade do terreno e o passante na rua não a vê. (...) É um exercício bem sucedido de gradação e analogia entre o novo e o antigo". (PUHL, 2010) No Largo das Forras o Galpão que abriga a Associação dos Artesãos, o Restaurante Sapore de Itália e o Restaurante da Vovó afastam-se um pouco do "estilo patrimônio" e se aproximam dessa terceira via pela proporção de galpão no primeiro caso, pelo afastamento lateral no segundo e pelo alpendre de pedras e detalhes do mesmo material no terceiro caso. É importante ressaltar que eles não foram aprovados para construção com essas divergências em relação ao "padrão", mas sim reformados de forma a aproveitar sua forma original (que incluía essas divergências) e adaptar ao estilo padrão (ou "patrimônio) com o uso do telhado, cachorros, beirais, janelas, portas e cores recomendados pelo IPHAN. 


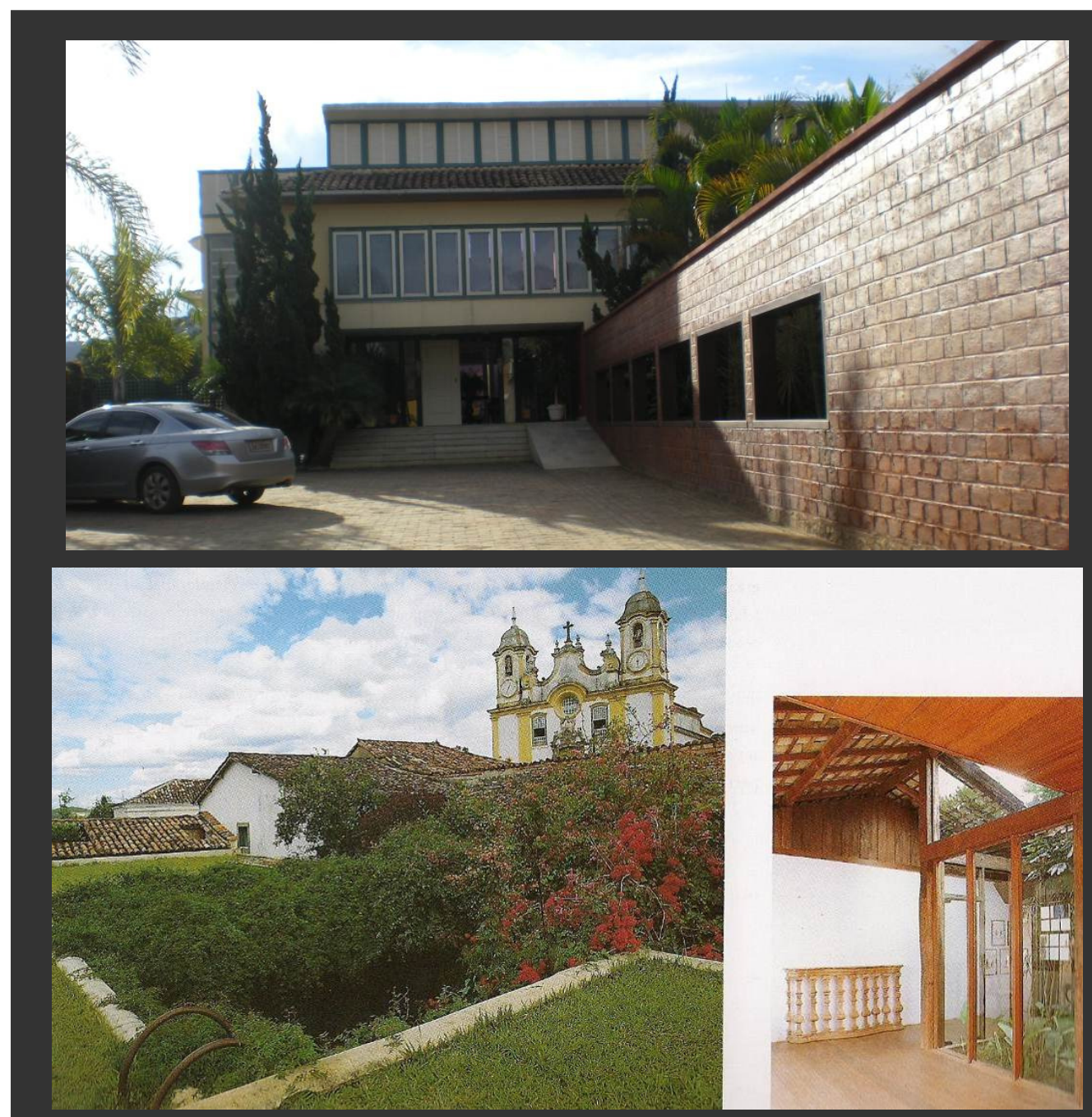

Foto 06: Pousada Dom Quixote em Tiradentes (2010). Fonte: Foto da autora.

Foto 07: Casa de Sylvia Nabuco em Tiradentes - detalhe do telhado de grama e do jardim de inverno [2007]. Fonte: Frota (2007:144).

Para analisar as três opções de intervenção apresentadas (o novo, o mimético e o 'meio termo’) é preciso recorrer a alguns clássicos da teoria do restauro.

Um dos primeiros a discutir sobre a legitimidade das intervenções em bens patrimoniais foi o inglês John Ruskin (1819-1900). Em seu livro "As sete lâmpadas da memória" está uma de suas afirmações mais famosas. O autor afirma que sem a arquitetura poderíamos viver, mais não poderíamos nos lembrar - resumindo o que o que considera característica mais importante de um bem patrimonial: o poder de rememoração. Para Ruskin 
(1981:210) esse poder estaria na ancianidade, na história do edifício contada por suas pedras, no que a "pátina do tempo" nos revela. Qualquer intervenção nesse bem patrimonial só seria aceita na medida em que buscasse a manutenção e o cuidado preventivo com o edifício, evitando um processo de restauração futuro. O autor prezava pela autenticidade material, condenando qualquer intervenção que modificasse, acrescentasse, retirasse ou copiasse no total ou em partes a edificação. Para ele a "alma" era dada ao edifício pelo primeiro construtor e o restauro seria "a mais completa destruição que um edifício pode sofrer" (CHOAY, 2001:155).

Contemporâneo de visão oposta, foi o francês Viollet Le Duc (1814-1879), precursor do restauro estilístico. Para ele o restauro restabeleceria "um estado completo que pode jamais ter existido". Le Duc prezava pela estética, o que justificaria acréscimos, remoções, modificações que levassem o edifício a um "estilo puro" e utilizassem tecnologias que, segundo ele, seus antecessores teriam usado se dispusessem do que ele dispunha naquele momento. Por ter essa forma de pensar, Choay (2001:158) declarou que Viollet Le Duc teria uma "nostalgia do futuro".

Posições intermediárias surgiram na Itália com Camilo Boito (1836 - 1914) e Gustavo Giovannoni (1873 - 1947), defensores de um restauro criterioso que não criasse os "falsos históricos", isto é, que não induzissem o observador ao erro - como, por exemplo, considerar um acréscimo ou complemento recente como original. Outra máxima do restauro científico (ou filológico, como foi denominado esse movimento) era a mínima intervenção aproximando-se mais de Ruskin, nesse sentido. Eram a favor do uso de neutros para preenchimento de lacunas e da anastilose.

As ideias desses teóricos sustentam grande parte da teoria do restauro contemporânea, ao defenderem ideias como a preservação da arquitetura "menor" (Ruskin), o uso como principal forma de conservação (Le Duc), registro da intervenção com criação de relatórios 
técnicos e, se possível, placas interpretativas sobre o restauro (Boito) e a necessidade de adaptação do bens patrimoniais urbanos às necessidades das sociedades em que se inserem (Giovannoni).

Ao comparar essas diversas e históricas interpretações do que seria e como deveria ser preservado um patrimônio percebemos que na década de 1930 as ações de intervenção empreendidas no Brasil sustentam uma visão parecida com a de Viollet Le Duc - priorização da estética e do estilo. Por esse motivo o preenchimento dos vazios com uma arquitetura em “estilo patrimônio" foi predominante na cidade de Tiradentes e no Largo das Forras.

Os conjuntos e a arquitetura civil (os grandes monumentos geralmente pertenciam à classe de edifícios religiosos ou militares) passaram a ter espaço nas discussões de restauro e preservação apenas no século XX, tendo sido legitimados como patrimônio, sobretudo, depois da carta de Veneza de 1964:

A noção de monumento histórico compreende a criação arquitetônica isolada, bem como o sítio urbano ou rural que dá testemunho de uma civilização particular, de uma evolução significativa ou de um acontecimento histórico. Estende-se não só as grandes criações, mas às obras modestas que tenham adquirido, com o tempo, uma significação cultural. (CARTA DE VENEZA, 1964:art 1)

No caso de Tiradentes é dada grande importância ao conjunto, e menor importância ao bem individual. É uma opção justificável, já que o conjunto possui muito mais expressão que as singelas edificações isoladas.

A prevalência do valor do conjunto ainda hoje fica clara em uma recente decisão jurídica do Supremo Tribunal Federal sobre a ação que envolveu um edifício não considerado patrimônio por sua proprietária e considerado patrimônio pelo IPHAN por estar circunscritos à área histórica - ainda que não pertencesse ao período colonial. A proprietária foi condenada ${ }^{8}$

\footnotetext{
${ }^{8}$ SUPREMO TRIBUNAL DE JUSTIÇA. RECURSO ESPECIAL No 1.098.640 MG (200802255289) Disponível na Revista Eletrônica de Jurisprudência.
} 
a demolir acréscimos que havia construído em seu imóvel no Largo das Forras. Ela entendia que, uma vez que não existia um registro individual de seu imóvel, não existiria obrigatoriedade de se seguir os protocolos de um bem tombado. O juiz entendeu, contudo, que o tombamento geral da cidade de Tiradentes obriga todos os proprietários (independente da característica do imóvel) a solicitar autorização para qualquer tipo de obra.

E exatamente por se tratar de tombamento de todo um conjunto arquitetônico e paisagístico, o procedimento seguido moldou-se ao peculiar caráter coletivo do bem em consideração. De fato, o art. $9^{\circ}, \mathrm{n}^{\circ} 1$, do Decreto-lei $\mathrm{n}^{\circ}$ $25 / 37$ se refere à notificação do proprietário da coisa tombada. Tal exigência, entretanto, não tem aplicação literal quando a coisa tombada não se traduz em bens individualmente considerados, mas sim no complexo de relações formadas por um sem número de elementos como casas, igrejas, chafarizes, ruas, largos, estações ferroviárias, pontes e edifícios, cujas interações recíprocas conformam um conjunto arquitetônico e urbanístico, no qual é inclusive de todo impossível identificar com precisão todos os proprietários de todos os bens do mesmo integrantes. Dessa maneira, a notificação a que alude o Decreto-lei $n^{\circ} 25 / 37$, no caso específico do centro histórico de Tiradentes foi realizada na pessoa do chefe da Administração Pública Local, a qual competia zelar pela preservação das funções urbanísticas objeto do ato protetivo em questão (STJ 2008:310)

A posição recente do juiz ${ }^{9}$ mostra grande coerência com os valores tombados em 1938, que privilegiavam a manutenção do estilo e a valorização da estética do conjunto homogêneo.

A proteção do conjunto tem a seu favor, ainda, o argumento jurídico da função social da propriedade privada, que deve atender à coletividade e a defesa dos direitos difusos, como direito à memória e à fruição da paisagem.

A valorização do conjunto dos imóveis e do valor artístico desse conjunto é explicitada na descrição que Frota (2005:59) faz da cidade:

\footnotetext{
${ }^{9}$ Esse caso específico trouxe, no entanto, grande repercussão por não haver unanimidade jurídica quanto à legitimidade de um tombamento inespecífico. Há autores como Carvalho Filho (2007) que defendem que os bens, conforme se prevê em lei, devam ser descritos e registrados para serem protegidos. Já autores como Maria di Pietro (2003) acreditam que o tombamento geral tem como alvo não a soma dos bens individuais, mas o conjunto, a coletividade - e este sim deve ser descrito.
} 
Dentro desse amplo arco [entre a última fase do Renascimento e o novo surto clacissista], fixaremos aqui os monumentos excepcionais que, em Tiradentes recebem a denominação genérica de barroco. Sem esquecer, no entanto, que é a sua inserção no núcleo urbano, no todo, que lhes oferece a moldura, e, mais que isso, a organicidade e o diálogo plástico de massas, cores, planos e volumes, alternâncias com verdes e integração na topografia, que os torna elementos de língua geral como expressão de um gosto, um tempo, uma maneira de entender e de sentir a vida.

O homogêneo é esteticamente agradável, mas existem também as vantagens de se manter um conjunto heterogêneo, tal qual foi sendo construído - orgânico - como ressalta Rogério Leite (2007:27) para o caso do bairro do Recife:

Costuma-se dizer, no Recife, que o bairro é um dos poucos lugares onde é possível contar, de forma concisa, a história da arquitetura e do urbanismo brasileiros. A afirmação baseia-se no fato de ele apresentar uma justaposição de estilos e traçados que permitiria perceber desde aspectos do Brasil colônia até exemplares da arquitetura moderna.

É importante ressaltar, ainda, que uma política de preservação do conjunto não pode nunca ignorar as peças que o compõe ${ }^{10}$. Em Tiradentes há uma tentativa do IPHAN de monitorar todo o conjunto e, ao mesmo tempo, cada um dos imóveis. O corpo técnico disponível, contudo, não é suficiente e há, ainda, uma resistência da população com relação às normas estabelecidas pelo IPHAN, como detalharemos mais adiante.

Voltando a discussão do preenchimento dos vazios presentes nesse conjunto, Cesare Brandi (1906-1988), um dos teóricos recentes mais respeitados da teoria do restauro, acredita que um bem se divida em 'estrutura' (aquilo que dá suporte) e 'aspecto', ('epifania da imagem'), sendo o primeiro de fácil intervenção ou mesmo substituição, enquanto que o

\footnotetext{
${ }^{10}$ Como ilustra bem uma alegoria de Calvino (1990:79):

Marco Polo descreve uma ponte pedra por pedra.

- Mas qual é a pedra que sustenta a ponte? - pergunta Kublai Khan.

- A ponte não é sustentada por esta ou aquela pedra responde Marco -, mas pela curva do arco que estas formam. Kubai Khan permanece em silêncio, refletindo. Depois acrescenta: - Por que falar das pedras? Só o arco me interessa. Polo responde: - Sem pedras o arco não existe.
} 
responsável pela imagem é "insubstituível, uma vez que forma o aspecto e não a estrutura"(JOKILEHTO, 1985:238). Esse pensamento fez com que Brandi negasse os neutros - técnica incentivada pelos defensores do restauro científico, sobretudo Giovannoni, que utilizavam de peças "neutras" para recompor conjuntos e obras delapidados. Para Brandi a inserção de uma figura "neutra" dentro de um todo nunca poderia criar um resultado neutro. A permanência de lacunas ou a inserção de um objeto neutro, por si só criariam novas imagens e deformariam a imagem original. Brandi, adepto das teorias da gestalt que afirmam ser o todo muito mais que a simples soma das partes, defendia o preenchimento de lacunas, o que significa criar um novo pedaço mimético ao original com o intuito não de copiá-lo (e assim profaná-lo), mas de completar o conjunto que seria, esse sim e não sua parte, uma obra de arte incopiável e irreplicável. Carbonara (2006:36) acredita que para Brandi "por conseguinte, o restauro é considerado como intervenção sobre a matéria, mas também como salvaguarda das condições ambientais que assegurem a melhor apreciação do objeto".

Segundo as teorias de Brandi o restauro começaria no reconhecimento da obra de arte enquanto tal. A obra de arte em Tiradentes seria todo o conjunto e não os bens isolados. Essa percepção do conjunto enquanto obra de arte que merece preservação abre a possibilidade de se intervir para restabelecer a "unidade potencial da obra de arte", mas Brandi (2004) acredita que isso só deve ser realizado "desde que isso seja possível sem cometer um falso artístico ou um falso histórico"11.

\footnotetext{
11 Para Brandi (2004:114) a falsidade, que seria o oposto da autenticidade, está no juízo. Nada é autentico ou falso em si, essas características não são inerentes, mas atribuídas. E essa atribuição pode se basear em diferentes juízos. Brandi distingui cópia, imitação e falso. Uma cópia seria a "produção de um objeto semelhante a, ou reproduzindo um outro objeto; ou, ainda, no modo e no estilo de um determinado período histórico ou determinada personalidade artística, para nenhum outro fim a não ser uma documentação do objeto ou o prazer que dele se quer extrair". Uma imitação seria a "produção de um objeto como referido acima, mas com o intento específico de levar outros ao engano a respeito da época, da consistência material do autor". Por último, o falso se referiria a "imissão no comércio ou, de qualquer outro modo, difusão do objeto, mesmo que não tenha sido feito com a intenção de levar ao engano, como uma obra autêntica, de época, ou de matéria, ou de fabricação, ou de autores diversos daqueles que dizem respeito ao objeto em si".
} 
Seguindo esse pensamento os novos edifícios podem ser interpretados como um preenchimento de lacunas (considerando como obra de arte o conjunto), e não como um pastiche que teria como objetivo produzir um falso histórico.

Tiradentes enquanto conjunto tem um valor imagético forte. Enquanto bens isolados, com exceção da Matriz e alguns poucos exemplares como o Solar Ramalho e a Casa de Padre Toledo, é pouco significativa. Em Tiradentes não houve, e ainda não há, valorização do material ou da história. Há valorização da imagem.

Essa imagem, contudo, não foi sempre a mesma. Ela foi se transformando ao longo do tempo, tanto de forma orgânica quanto de forma programada.

\subsection{AS ORIGENS DO LARGO E SUA DESCONSTRUÇÃO}

O Largo das Forras não teve sempre o espaço central que ocupa em Tiradentes hoje. No início da ocupação (século XVII) era apenas um espaço residual na entrada da cidade, como coloca Salgado $(2007: 31)$

No início da formação da cidade de Tiradentes, observam-se duas grandes áreas localizadas no extremo da vila que precediam a entrada de viajantes, o largo das Forras e a Praça das Mercês que possuíam características espaciais de terreiros, local de transição entre as estradas e as ruas, entre o espaço civilizado urbano e a mata.

Uma de suas primeiras construções foi a Capela de Bom Jesus da Pobreza (1782) único exemplar arquitetônico do século XVIII remanescente na paisagem atual.

Ficou sendo esse o nome corrente, dado pelo povo à capela setecentista do Bom Jesus Agonizante, no Largo das Forras. Sofreu inúmeras reformas ao longo do tempo, e hoje [2005] se encontra em processo de restauração. A imagem do Cristo Agonizante no altar-mor, constitui a mais importante referência para a visitação deste pequeno templo. (FROTA, 2005:93) 
A adoção do nome 'Bom Jesus da Pobreza', em substituição ao original 'Bom Jesus Agonizante', segundo a placa interpretativa do atrativo" ${ }^{12}$ "indica a camada social de seus antigos freqüentadores". A exemplo desse grupo de usuários foi resgatado o nome original do largo - "das Forras" - em referência as negras forras que ali residiam. Nesse sentido a evolução toponímica da praça também conta parte de sua história e será explorada mais adiante.

Durante o período colonial a posição do Largo - na parte baixa e alagadiça da cidade contribuiu para sua designação de zona de serviços que se estabeleceu em contraste com a zona alta da cidade - próxima à Matriz, Câmara e Pelourinho - residencial e símbolo de poder. Por esse motivo o Largo não é citado nos relatos dos viajantes John Luccock, Johann Pohl, Saint-Hilaire, Spix e Martius, tendo todos se pronunciado, no entanto, sobre a beleza e imponência da Matriz de Santo Antônio.

No século XIX o Largo servia principalmente para estacionamento de carros de boi e carroças, além de espaço para a formação das tropas da milícia (DOSSIÊ, 2007). Sua superfície plana e a ausência de mobiliários urbanos no espaço onde hoje há a praça se adequavam perfeitamente a essas necessidades. Desse século ainda restam a ponte de pedra (construída por volta de 1800 na administração de João Antônio de Campos ${ }^{13}$ ), a Capela do Passo (construída em 1807 com material retirado de dois outros passos que foram demolidos $^{14}$ ), o sobrado onde hoje é a prefeitura (construção estimada em meados do século

\footnotetext{
12 Bastante questionável, deve-se ressaltar, já que não se encontra registros confiáveis que confirmem essa informação.

${ }^{13}$ Informação do historiador e funcionário do IPHAN Tiradentes Olinto Rodrigues dos Santos Filho, disponível em www.tiradentes.mg.gov.br

${ }^{14}$ Informação cedida pelo historiador Olinto dos Santos Filho em entrevista (2009).
} 
XIX) e a maior parte das edificações do sul da praça - com inúmeras e não bem documentadas modificações) ${ }^{15}$.

Com o escasseamento do ouro no final do século XVIII e início do XIX, segundo o Inventário da Prefeitura Municipal, "grande parte da população, que havia feito fortuna na época áurea, desceu para o Vale do Paraíba, onde se dedicaram ao plantio de café, formando as novas cidades do ciclo do café".

Com a decadência da exploração aurífera houve uma forte emigração para o campo (dentro do próprio município), onde a agricultura de subsistência e a criação de porcos para venda no Rio de Janeiro prevaleceram. A maioria das famílias que se mudou para a zona rural manteve, no entanto, sua casa na cidade. Aos fins de semana era para lá que todos se dirigiam em busca de satisfação das necessidades religiosas e de entretenimento (SALGADO, 2007:38).

A cidade de São João Del Rei ainda hoje é uma referência importante para os tiradentinos para compras e estudos - apesar de, atualmente, Tiradentes ter maior visibilidade nacional e maior número de visitantes. No período pós-esgotamento da mineração, contudo, a cidade vizinha foi fundamental para abastecimento de artigos que não chegavam a Tiradentes, além de acesso a estudos, empregos e entretenimento. Isso ocorreu, sobretudo, porque São João Del Rey, diferente de Tiradentes, passou por um processo de industrialização.

\footnotetext{
${ }^{15}$ Sabe-se que o edifício onde hoje funciona o Hotel Ponta do Morro foi até a década de 1940 sobrado da família Albuquerque. Nessa década Lourenço Campos demoliu o segundo andar e criou o atual portal, retirando a porta do centro (colocada na lateral da Capela de Bom Jesus da Pobreza) e inserindo um portão para transformar o local em garagem (de original há, portanto, apenas parte da fachada do primeiro andar). O sobrado onde hoje funciona o Hotel Mãe D’Água era uma casa baixa e pertencia a Eliseu Veloso. Não se sabe precisar a data, mas essa casa ruiu e no terreno foi colocada uma bomba de gasolina na década de 1960. Em 1971 Geraldo Conceição (conhecido como Mitula) constrói um restaurante e sua casa no terreno. Em 1994, com várias modificações, esse imóvel torna-se o hotel que existe até hoje. A Pousada do Largo de propriedade de Vanilce Barbosa desde a década de 1990, possui a fachada quase original (houve uma intervenção reprovada pelo IPHAN e, após decisão judicial, intervenção para resgate da forma anterior) com a parte interna complemente modificada. As propriedades de Francisco Lourenço aparecem no mapa do IBPC como novas intervenções, mas não há registro no IPHAN local da data em que foram construídas ou modificadas.
} 
Muitos autores sustentam que em Tiradentes houve uma estagnação de quase dois séculos. Richard Burton (1976:132) ao passar pela cidade em 1867 comenta de forma irônica que "as atividades em São José, a não ser comer jacuba ${ }^{16}$ e jogar peteca, estão paradas". Manuel Bandeira no Guia de Ouro Preto (1938:42) afirma que "não se pode dizer de Ouro Preto que seja uma cidade morta. Morta é São José del Rey”. O Jornal do Brasil ${ }^{17}$, três anos mais tarde, confirma essa imagem: "Velha, abandonada, decadente, quase em ruínas, ergue-se entre o Rio das Mortes e a Serra de São José a histórica cidade de Tiradentes”.

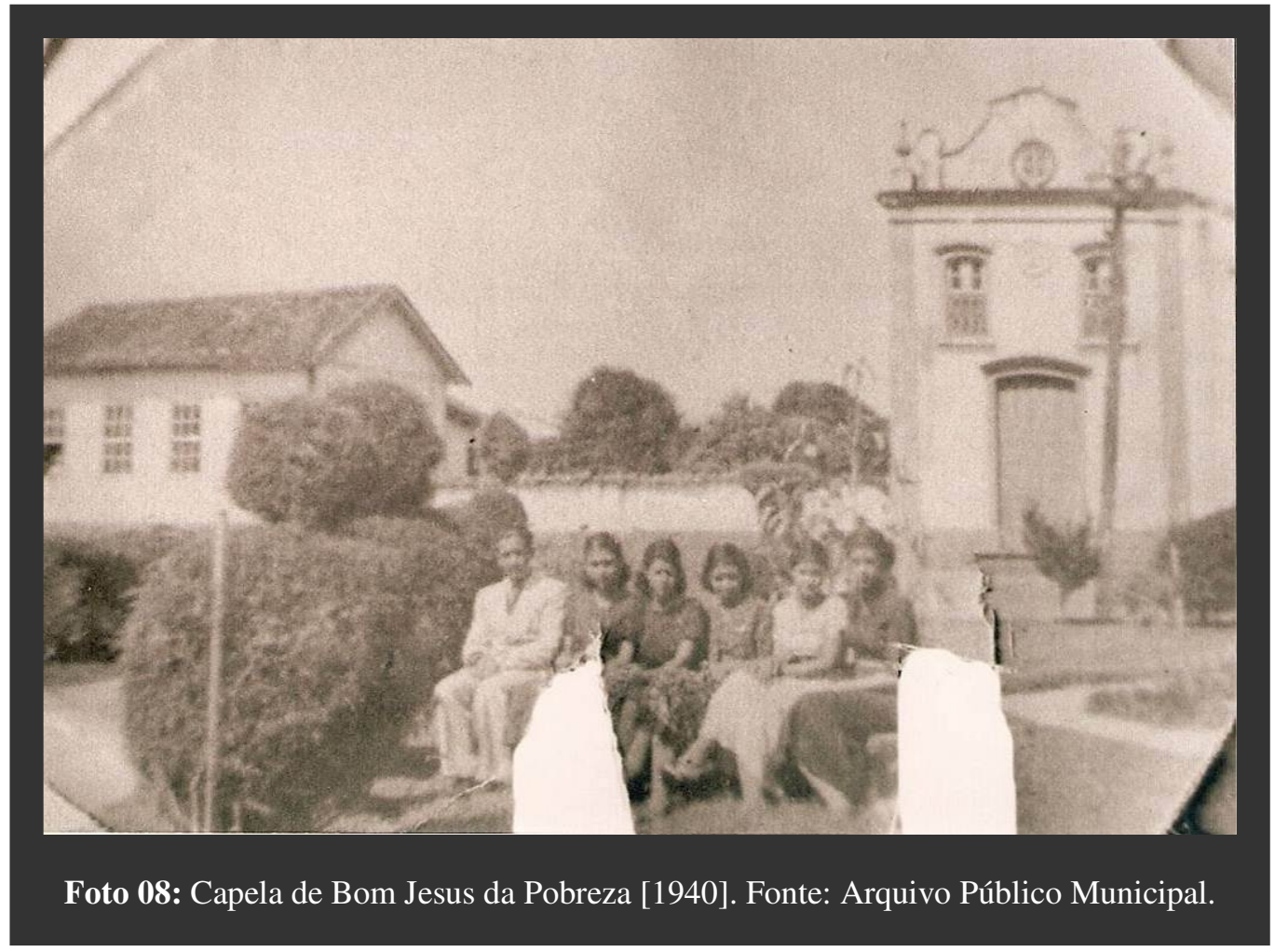

Estagnação, contudo, é uma um termo forte para definir um período durante o qual a cidade continuou a crescer (vide Figura 03) e houve investimentos como a Estrada de Ferro

\footnotetext{
${ }^{16}$ Prato muito utilizado pelos tropeiros, a base de rapadura e farinha.

17 "A tradicional Tiradentes" In: Jornal do Brasil 29.06.1941 e "Uma cidade marcha para morte", reportagem de Milton Pedrosa In: Diário de Notícias 29.10.1950. Ambos em Frota (2005:139)
} 
Oeste Minas inaugurada em 1881, o Barco a Vapor no Rio da Mortes, novo arruamento, ajardinamento e tratamento urbanístico das praças, asfaltamento do acesso à cidade, tombamento, dentre outros. Durante algum tempo, mesmo com escasseamento do ouro, a Mining Co Association atuou na cidade buscando alternativas mais tecnológicas de garimpo. Além da agropecuária (sobretudo suinocultura), havia na cidade olarias e a indústria têxtil atividades fortes ao longo de todo esse período. (FROTA, 2005:47)

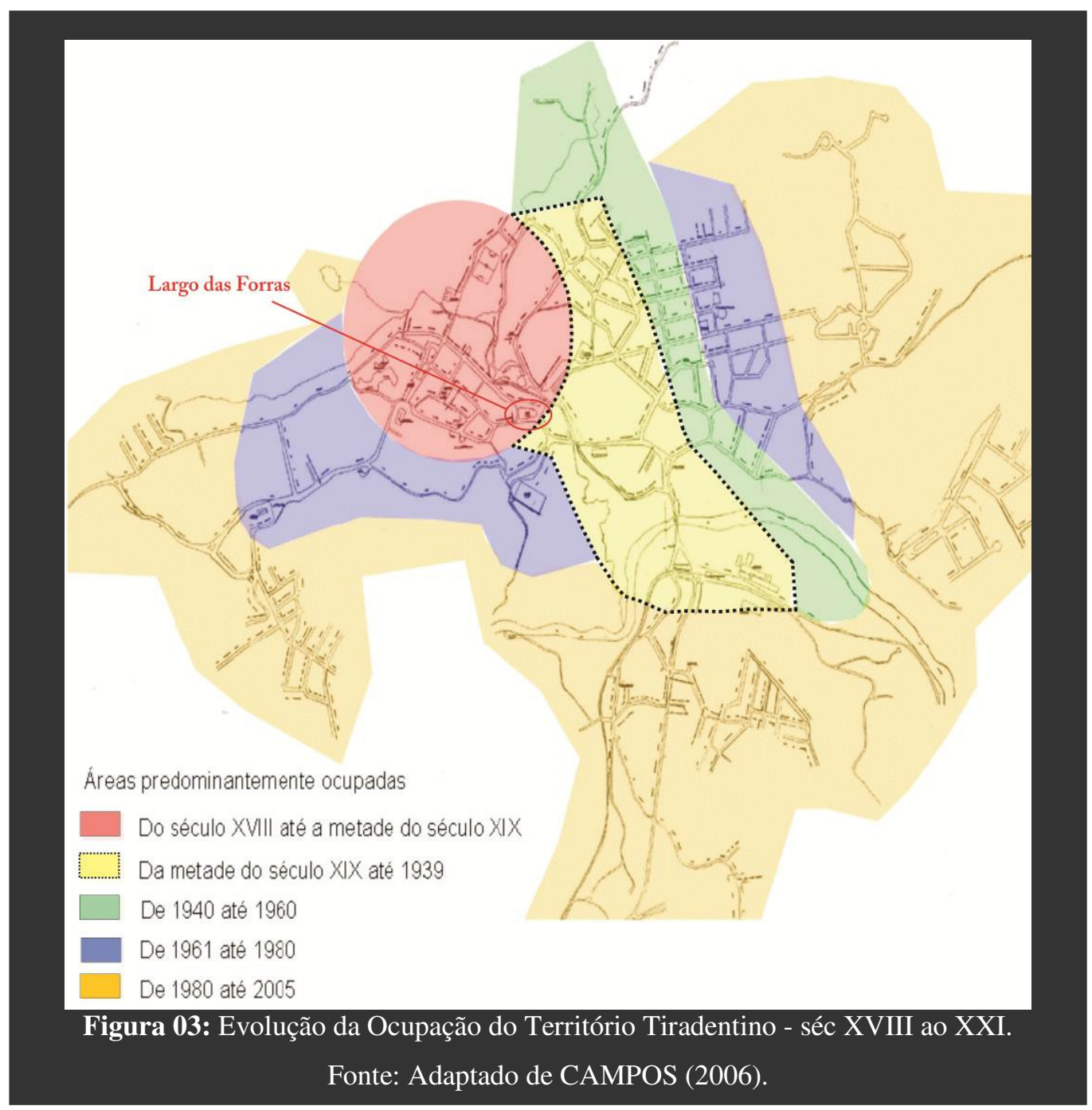


O declínio econômico do município trouxe benefícios e prejuízos ao patrimônio urbano. Provavelmente foi a causa da permanência de muitos imóveis, pela falta de recursos para novas construções, reformas e ampliações. Por outro lado, também foi a causa de perdas por falta de investimentos em manutenção. Segundo o jurista Edmundo Lins (1967:22), em 1882 "muitas eram suas casas [de Tiradentes] abandonadas e demolidas para aproveitarem-se as suas pedras e madeiramento em novas construções em São João Del Rey”. No Inventário Municipal encontra-se a informação de que "por volta de 1899/1900, a cidade contava com 194 casas bastante arruinadas, sendo 19 sobrados".

Monumentos de grande porte como a Igreja Matriz de Santo Antônio, a Casa do Padre Toledo, o Fórum, a Cadeia, construídos de taipa-de-pilão, eram infiltrados pela chuva e a sua integridade se achava ameaçada. Escoramentos, pequenas consolidações consecutivas com telha ou massa, as únicas então possíveis, não bastavam para assegurar a estabilidade desses edifícios de grande porte, realçados e ligados organicamente entre si pelo casario. (FROTA, 2005:111)

Os imóveis antigos do Largo também sofreram com esse período de desinvestimento. Estima-se $^{18}$ que na primeira metade do século XX tenha desabado a casa de um pavimento onde residia Elizeu Veloso - hoje sobrado que abriga Hotel Mãe D’Água.

Mas os investimentos do poder público na cidade, como já colocado, ainda que tivessem diminuído, não cessaram. Alguns anos antes do tombamento, em 1892, foi criado um primeiro jardim com formatos poligonais no Largo das Forras (foto 03) em comemoração à República instituída há três anos e à mudança do nome da cidade de São José para Tiradentes - homenagem ao inconfidente Joaquim José da Silva Xavier, natural da cidade. Junto com o jardim foi construído o Monumento Tiradentes.

\footnotetext{
${ }^{18}$ Entrevistas com Olinto dos Santos Filho (técnico do IPHAN local), Rogério Almeida (responsável pelo Arquivo Municipal) e Cínthia Campos (historiadora da Prefeitura Municipal) - 2009.
} 
Os monumentos, segundo Choay (2001:25), são elementos criados para deliberadamente invocar uma memória. No caso do Largo o Monumento Tiradentes intencionava não apenas homenagear uma personagem de importância nacional nascida naquelas terras, como também fortalecer a ideia de independência, provavelmente para que as gerações futuras viessem a se lembrar da luta de seus antepassados pela república e a necessidade de mantê-la.

O Monumento Tiradentes foi construído em 1892 pela recém-criada "Sociedade Comemorativa do Centenário do Tiradentes" que teve como objetivo promover as comemorações em homenagem ao Herói da Inconfidência.

Muitos membros foram convocados para fazer parte da Sociedade, alguns como honorários como Timóteo Antunes, o governador José Cezário Alvim, o Conde de Figueiredo, o Dr. João Pinheiro da Silva. A diretoria era composta pelo Comendador Carlos de José Assis, presidente; Francisco de Paula Vilela secretário e Francisco Teodoro da Fonseca, tesoureiro. Foram impressos em Juiz de Fora 500 diplomas para os sócios e 300 exemplares dos estatutos, não localizados. Gastou-se ainda no ano de 1892 com a limpeza do largo das Forras para os festejos e material para construção do monumento, camadas de pedra e lajes, mas não encontramos os recibos detalhados. (DOSSIÊ, 2007)

Em suas origens o formato era o de uma urna funerária (apenas simbólica, pois não guardava os restos mortais de Tiradentes) sobre um pilar de aproximadamente $1,5 \mathrm{~m}$ de altura (que por sua vez fica sobre degraus que alcançam um pouco mais de meio metro) e tinha quatro mini postes de onde saiam correntes que circundavam o monumento - para protegê-lo ou, mais provavelmente, dar à escultura um status de obra de arte, de algo que deve ser conservado. Não se sabe bem quando nem como, mas essa urna sumiu. Em 1932 o artista local Antônio Gomes faz um busto de Tiradentes para ornamentar o pilar, em substituição à urna que desaparecera. $\mathrm{O}$ artista também fez as flores da base do pilar. A escultura, contudo, não agradou a maioria. Segundo Olinto dos Santos Filho, as pessoas dizem que ela ficou grande demais para o Pilar e, portanto, desproporcional. Ela foi retirada e se encontra 
atualmente guardada na Biblioteca Municipal. Durante um tempo o vazio foi preenchido por um vaso de flores que ficava na Casa de Padre Toledo, mas desde 1970 esse vaso foi retirado e até os dias de hoje permanece vazio - apenas o pilar ornamentado.

Recentemente foi construído um outro busto de Tiradentes para reforçar a homenagem a esse tiradentino, desta vez colocado no Largo do Sol.

O Largo do Sol se situa hoje onde no século XVIII concentrava-se os símbolos de poder (Câmara, Matriz e Pelourinho) e é provável que tivesse recebido o monumento em 1892 se nesse período existisse o Largo - ele surgiu com a demolição de uma casa no início do século XX.

A escolha do Largo das Forras para a localização do monumento demonstra que algumas décadas antes do tombamento já havia a intenção de valorizar aquele espaço. Apesar de ser um espaço residual e fora da centralidade principal da vila colonial, o Largo era usado frequentemente para realização de eventos que exigissem grande concentração de pessoas, montagem de palcos ou palanques. No final do século XIX sua localização e imagem não eram valorizados como são atualmente, mas o Largo tinha valor por seu formato espacial (plano) e sua proporção (ampla). 




Foto 09: Novo busto de Tiradentes (1932). Fonte: Arquivo Municipal.

Foto 10: Largo das Forras com o Busto [1940]. Fonte: Arquivo Municipal.

Foto 11: Monumento Tiradentes (2010). Fonte: Foto da autora.

Foto 12: Busto de Tiradentes guardado na Biblioteca (2010). Fonte: Foto da autora. 
O tombamento de 1938 trouxe uma valorização externa e um novo olhar para o Largo das Forras - ele agora era patrimônio e como tal deveria receber um tratamento especial. Nesse mesmo ano foram plantados os fícus na praça, um cuidado com a estética que demonstra uma preocupação com o recém-declarado patrimônio. Nessa intervenção urbana a praça ganha formato poligonal e jardim geométrico.

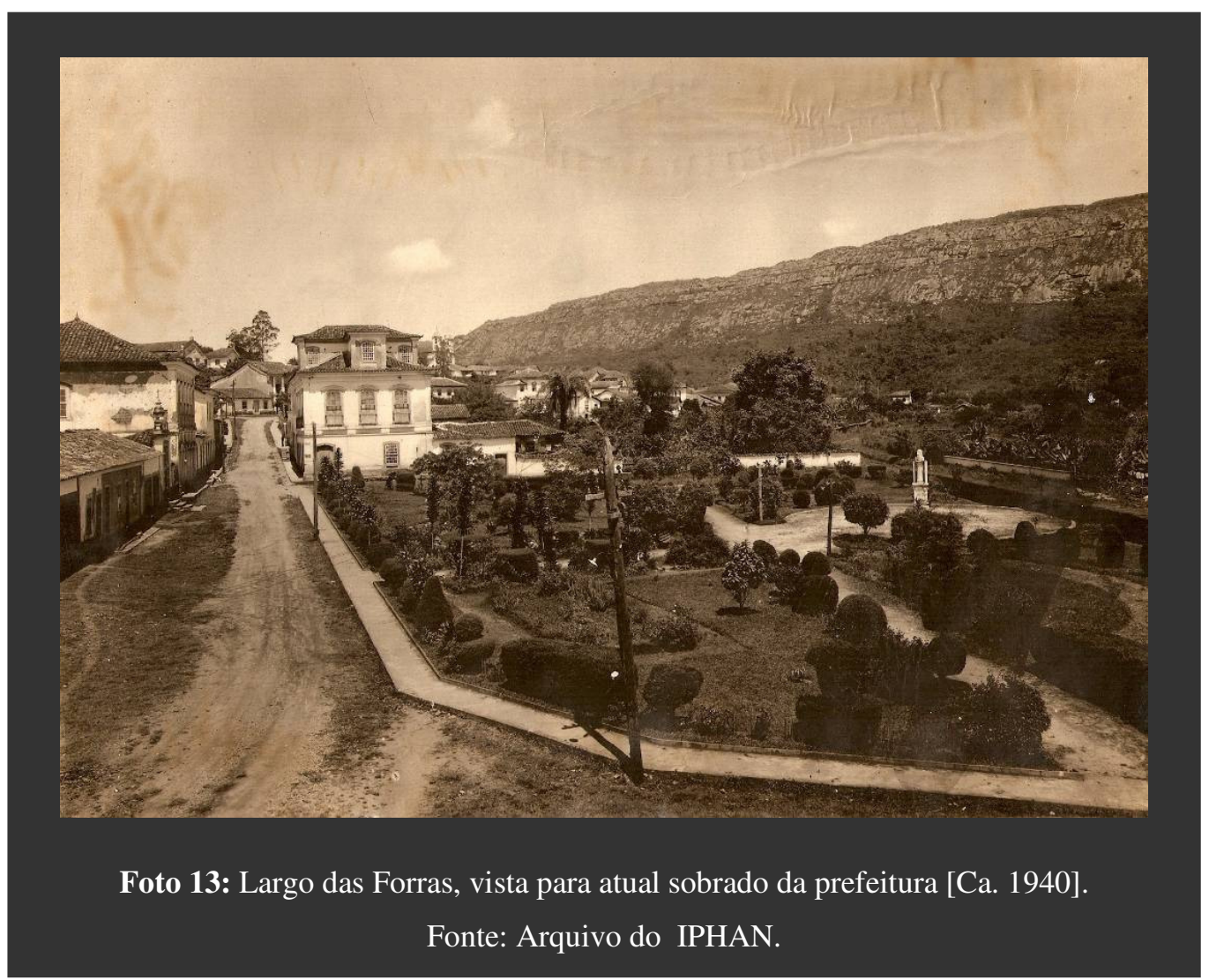

Segundo o relatório do IBPC (1997:23)

(...) a construção do jardim no Largo das Forras ou a demolição do sobrado da Rua Direita, abrindo o Largo do Sol, nos sugerem que as transformações sociais no século XIX / XX, em que a mentalidade voltada para a higienização preconizava a abertura de espaços urbanos e jardins burgueses para passeios / deleite, parecem de alguma forma, terem sido ensaiadas em Tiradentes.

Segawa (1996:70) confirma essa tendência no Brasil no início do XX quando “o conceito da rua e do parque arborizados como pulmões urbanos estava amplamente 
assimilado. Não apenas em sua dimensão salubrista, como por um suposto caráter cívico". Nessa época "o conhecimento sobre os benefícios das plantas na área urbana estava divulgado nas mais diversas instâncias sociais e plenamente aceito do ponto de vista técnico-científico". Dessa foram era comum o "processo de ajardinamento dos 'vazios urbanos' que se registrou nessa época — incluindo aí a construção de canteiros em adros e largos de igrejas (...)”.

A despeito do tombamento realizado em 1938, logo no início da década de 1940 e sem autorização do IPHAN, Lourenço Campos desmancha o segundo andar do sobrado em frente à prefeitura (foto 13), retira a porta central (colocada na lateral da Igreja de Bom Jesus da Pobreza) e substitui por um portão. Esse local passa a funcionar como garagem para seu ônibus. Rodrigo Melo Franco de Andrade (1997:77) reconhece que há um problema generalizado nas cidades tombadas em Minas quando afirma que "apesar do tombamento, parte considerável das cidades aludidas têm sido desfiguradas mais ou menos gravemente".

O patrimônio não atuou apenas em 1938. Em 1946 o DPHAN ${ }^{19}$ realizou uma série de obras com fins de salvaguardar o patrimônio mineiro. Em Tiradentes foram restauradas a Igreja do Rosário, Nossa Senhora dos Mercês e a Matriz de Santo Antônio (ARAÚJO, 2004:14). Desse período até 1989 foram tombados em nível federal dez imóveis, dentre eles a Igreja de Bom de Jesus da Pobreza (inscrição em 1964) localizada no Largo.

Há que se ressaltar que a presença institucional do IPHAN através do tombamento de 1938 do acervo arquitetônico e paisagístico da cidade, e posteriormente do tombamento de várias edificações religiosas e civis implicou na maior valorização e divulgação do acervo local, quer como objeto de interesse dos estudiosos, quer como potencial turístico, o que, entretanto, não tem assegurado à cidade, em nível satisfatório, a integridade física, impedindo que ocorram alterações descaracterizadoras do núcleo histórico. (FUNDAÇÃO JOÃO PINHEIRO, 1980:11)

\footnotetext{
${ }^{19}$ Diretoria do Patrimônio Histórico e Artístico Nacional. Sigla posterior a SPHAN (Serviço) e anterior ao atual IPHAN (Instituto).
} 
Na década de 1940 o terreno ao norte da praça (foto 03) é doado pela prefeitura a Francisco Araújo Lima. Esse terreno vai ser finalmente ocupado por Lourenço Campos em 1950, quando ele que constrói uma casa para sua família (DOSSIÊ, 1997).

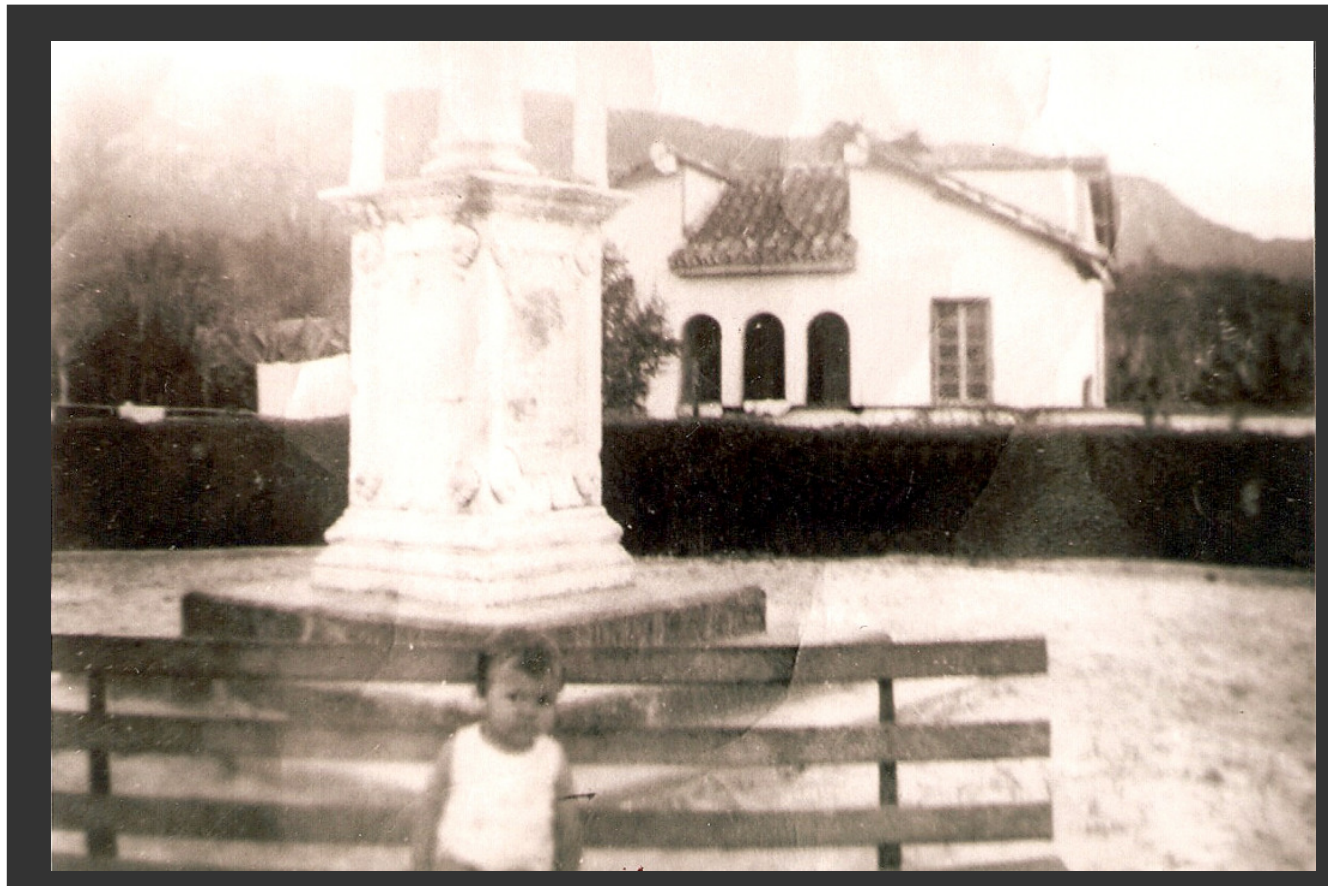

Foto 14: Monumento e casa de Lourenço Campos [Ca.1960]. Fonte: Arquivo Municipal.

A tipologia arquitetônica utilizada na casa (foto 14) demonstra claramente que não havia uma política efetiva de uso dos vazios da área patrimonial em consonância com os critérios estéticos adotados no tombamento. Era obrigatória a retirada de autorização para construção no IPHAN, mas não houve nenhuma restrição ou direcionamento em relação à volumetria, formato, material, técnica ou nenhum outro tópico que pudesse influenciar a harmonia do conjunto colonial. Esse posicionamento demonstra muito mais a incapacidade do IPHAN em assumir, naquele momento, o controle dessas alterações - que exigem técnicos e fiscais - que a própria política adotada. $\mathrm{Na}$ década de 1950 se adotava a arquitetura mimética sem as preocupações que há hoje (já que a estética prevalecia sobre o documental e a construção em "estilo patrimônio" era prática corriqueira), o que não justificaria a 
autorização de uma construção em estilo tão diverso do conjunto. Contudo, nos primeiros anos de gestão do patrimônio tiradentino não havia escritório local (criado somente em 1983) o que inviabilizava um controle efetivo, já que o escritório responsável ficava no Rio de Janeiro, há 450 km. Frota (2005:111) ressalta que "a distância, a dificuldade de comunicação, o reduzido corpo técnico do recém-nascido SPHAN e principalmente a desinformação local sobre o patrimônio cultural não teriam produzido então os resultados almejados por Rodrigo [Melo Franco de Andrade]”. Os resultados a que Frota se refere seria a efetiva preservação que dependeria de instrução, monitoramento e fiscalização.

Na década de 1960 Francisco Araújo Lourenço (conhecido como Chiquinho do Bar) doa parte do seu terreno para abertura da Rua dos Inconfidentes, ao lado da Igreja de Bom Jesus da Pobreza. Até então havia apenas um beco, mas sentiu-se a necessidade de abrir espaço para o tráfego de veículos. Só então o Largo passa a ter as quatro entradas (ruas) que o configura até os dias de hoje.

A rua também se modificou. Segundo o inventário turístico municipal, "entre 1959 e 1963 o antigo calçamento de pé de moleque setecentista foi substituído por grandes lajes de quartzito extraídas da Serra de São José".

Em 1966 Lourenço Campos fragmenta seu terreno, doando lotes a seus filhos Margarida e José da Natividade (onde hoje São os Restaurantes da Vovó e San Felice números 6 e 8, respectivamente, na figura 04), construindo um grêmio recreativo em 1971 (onde hoje é o Restaurante Mandalum - $\mathrm{n}^{0} 5$ na figura 04) e uma casa para Mariana Santos (onde hoje é a sorveteria Chaplin - $\mathrm{n}^{\mathrm{o}} 10$ na figura 04 ) próxima à ponte de pedra, ocupando toda a frente do lote.

Na mesma década, especificamente em 1963, José Wiermann (conhecido localmente como Zé do Caroço) construiu uma casa para sua família a noroeste da praça $\left(n^{\circ} 4\right.$ na figura 04). Em 1968 é construído em frente à sua casa um posto de gasolina. 
Após o tombamento geral da cidade e de sua valoração como patrimônio, inicia-se um processo de valorização do Largo das Forras. Uma das consequências foi a necessária desconstrução de sua imagem marginal e de seu posicionamento periférico em relação à cidade. Agora ele era parte integrante da recém-criada "cidade histórica" e precisava assumir o papel de lugar de memória, de centro histórico.

O Largo da Forras vai, aos poucos, se desfazendo do estigma de espaço de serviço / área periférica. Desde a inserção do monumento Tiradentes e sobretudo depois do tombamento de 1938, o espaço vai ganhando novas formas e significados. No final da década de 1960 o Largo pode ser considerado um espaço central e símbolo de poder, já que possui uma capela (Bom Jesus da Pobreza) e um Passo representando a Igreja Católica (expressiva e poderosa em Tiradentes), o Monumento Tiradentes (monumento cível símbolo da república e homenagem ao inconfidente natural de São José) e a Prefeitura Municipal (transferida para o sobrado em 1961), além de se tornar um dos principais espaços públicos e sede de eventos da cidade.

Isso acontece, entre outros motivos, porque os padrões espaciais (HOLANDA, 2002) do Largo estimulam a co-presença pelo formato convexo (a possibilidade de enxergar todo o ambiente de qualquer ponto traz conforto ao expectador - figura 04) e pela ausência de eixos cegos (todos os lotes tem entradas - portas - o que aumenta a apropriação). As múltiplas entradas (quatro ruas) também aumentam potencialmente o fluxo no espaço.

O Largo faz parte de um sistema de integração profundo (ou assimétrico), típico de cidades barrocas, que torna a leitura do espaço urbano mais difícil pela ausência de eixos axiais (ruas retas). Contudo, o Largo pode ser considerado um núcleo integrador por sua localização, pois além de haver uma grande economia da malha (distâncias curtas) no centro histórico, pode-se dizer que (quase) todos os caminhos levam ao Largo. 


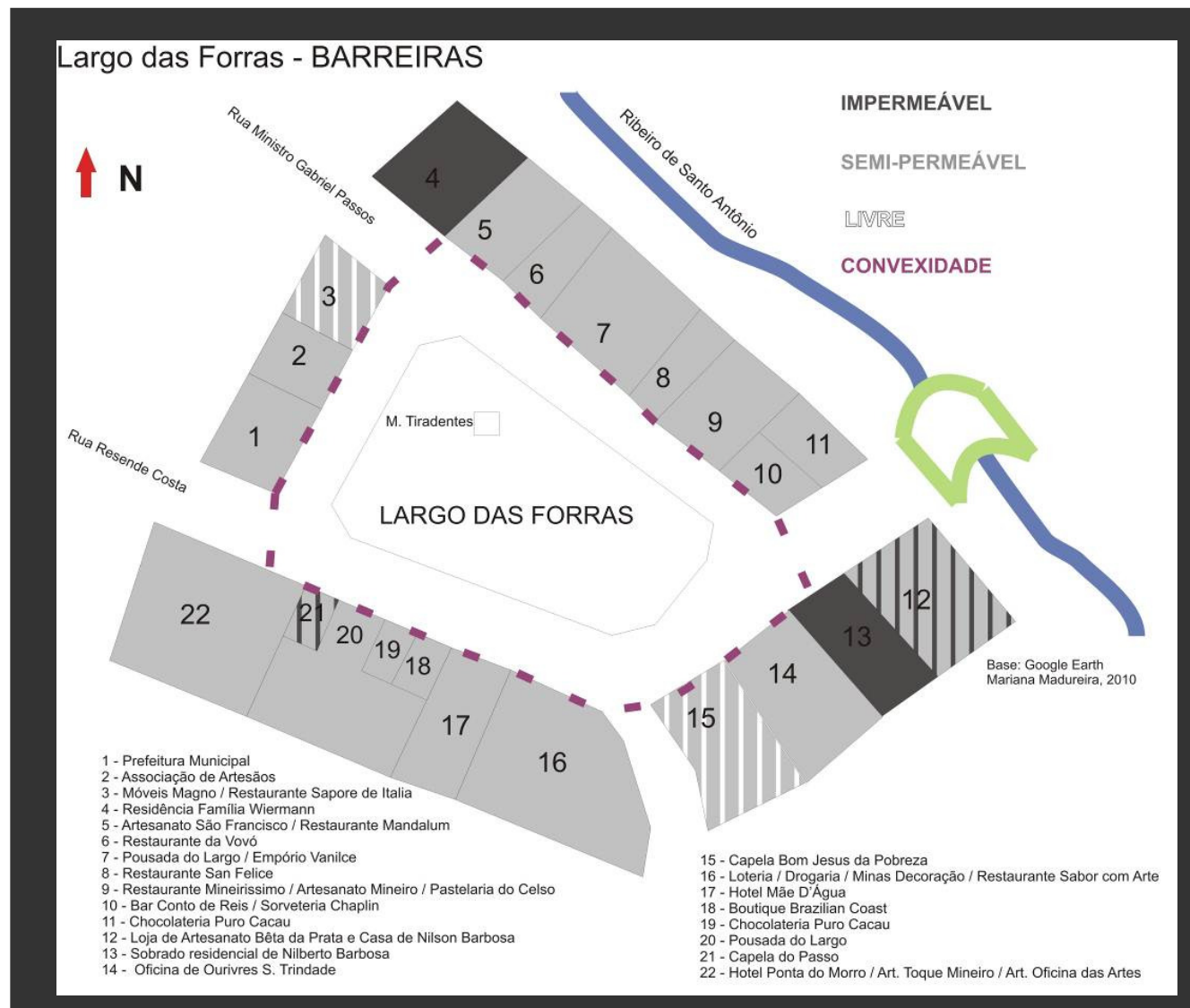

Figura 04: Mapa de Barreiras e Convexidade. Fonte: Ilustração da autora (2010).

A permeabilidade do Largo é muito alta, como se pode ver no mapa de barreiras (figura 04), no qual os espaços brancos representam a livre circulação e os pretos os espaços privados - sendo o cinza a representação para os espaços semi-públicos. Os espaços listrados de cinza e branco representam espaços que, além de semipermeáveis por seu uso, são mais abertos que os demais pela presença de pátios ou jardins. O Passo aparece listrado de cinza e preto porque, apesar de ser uma construção da igreja para acesso dos fiéis e visitantes, fica aberto apenas durante as procissões da Semana Santa. O Bêta da Prata, por sua vez, encontrase listrado no mapa por ter o primeiro andar comercial (semi-permeável) e o segundo andar residencial (privado). 
Além do espaço da praça, que incentiva a permanência com seus bancos e mesas, sob a sombra das árvores de fícus, os imóveis da praça são na atualidade, quase todos, abertos ao público por seu uso para fins comerciais e de prestação de serviços.

A evolução toponímica do Largo é outra forma de ilustrar as fases pelas quais o espaço passou. Na sua origem setecentista foi batizado de Largo das Forras como referência às negras forras que ali moravam. Em 1884 um projeto de lei altera seu nome para Praça da Liberdade, em um afã republicano de representar os novos tempos. Por volta de 1936 ou 1937, Benedito Valadares passa a ser o nome da praça por solicitação do próprio político que, durante esse período, renomeou diversas praças em homenagem a si mesmo. Em 1974 a praça passa a se chamar Berço da Liberdade, invocando o status de terra natal do inconfidente Tiradentes e retomando, de certa forma, o nome anterior - mais condizente com a identidade local. Por último, em 1978, por iniciativa do Instituto Histórico Geográfico de Tiradentes, houve um processo de resgate dos nomes originais ${ }^{20}$. A Rua Direita e a Rua Jogo de Bola são exemplos de espaços que retomaram seus nomes de origem nesse projeto. Nesse momento o Largo das Forras reassume seu primeiro nome.

A intenção de retomar as raízes coloniais fica clara nesse último projeto. Couto (2003:124) acredita que as cidades resgatam nomes para invocar o que já perderam ou deixaram pra trás.

A recuperação dos nomes de origem que fizeram sentido em um contexto que não existe mais parece uma tentativa de resgatar um lugar idealizado em nome da memória coletiva. Esse resgate auxiliou, sobretudo, na formação da imagem. Nada mais conveniente para a consolidação de um lugar de memória setecentista que um nome setecentista.

A criação de uma nova imagem somada à refuncionalização do Largo das Forras (processo que aqui estamos chamando de desconstrução) durou aproximadamente quatro

\footnotetext{
${ }^{20}$ Informação dada por Olinto do Santos Filho em entrevista (22/10/2010).
} 
décadas. Nas décadas de 1960 e 1970 vai ocorrendo uma progressiva ocupação dos últimos vazios da praça e o surgimento de usos comerciais locais como o Grêmio Recreativo de Lourenço Campos, o Correio de Francisco Barbosa, o Restaurante de Mitula (Geraldo Conceição), o banco Bamerindus, o posto de gasolina e as primeiras pratarias.

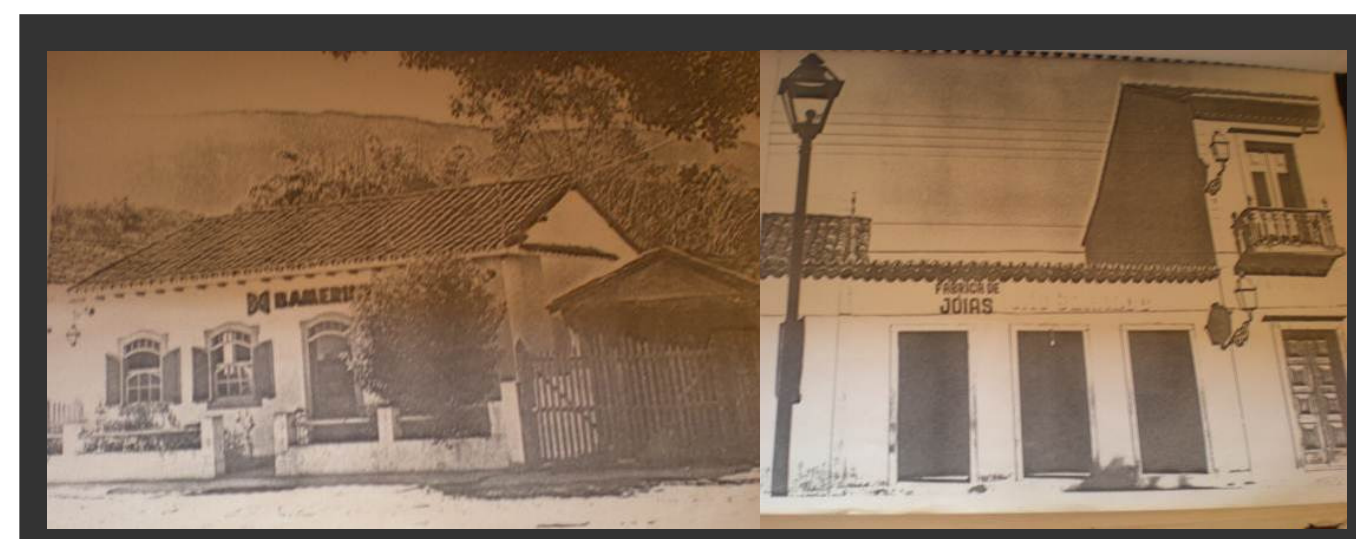

Foto 15: Banco Bamerindus (1980). Fonte: Fundação João Pinheiro. Foto 16: Prataria (1980). Fonte: Fundação João Pinheiro.

Este novo espaço é muito diferente daquele criado no século XVIII. Pode-se dizer, portanto, que o Largo das Forras foi construído como um espaço marginal no século XVIII, desconstruído enquanto espaço marginal no século XX (até 1970) - tornando-se espaço central com apropriação de famílias tradicionais e concentração de símbolos de poder.

No final do século XX esse espaço (construído e desconstruído) será reconstruído enquanto um novo espaço, especificamente um espaço de consumo, um território turístico. 


\subsection{A GESTÃO DO NOVO LUGAR}

Márcia Sant'Anna (1995) divide a preservação de áreas urbanas no Brasil em três fases: A primeira, denominada Cidades Monumento, foi o período em que o patrimônio pretendeu-se construtor de uma identidade nacional (fase heróica de Fonseca). Buscou-se qualidade arquitetônica e integridade dos bens, muito valor foi dado à homogeneidade do conjunto que, por sua vez, era tratado da mesma forma que um edifício tombado isoladamente. Segundo a autora essa fase perdurou de 1937 (criação do SPHAN) até 1967 (Carta de Quito).

Fonseca (1997:128) tece algumas críticas a respeito do SPHAN durante essa primeira fase (que ela classifica entre 1937-1964). O que não era problema então, mas é visto como ilegítimo segundo os paradigmas atuais, foi a falta de participação popular na escolha do que deveria ou não ser patrimônio. Naquele período os intelectuais modernistas eram o grupo mais indicado para tomar esse tipo de decisão e não havia, por parte de outros grupos ou da população de modo geral, a intenção de ter voz nesse processo. A fragilidade dos registros também foi apontada, já que, diferente do que se faz hoje, não houve laudos técnicos sobre a área de cada um dos imóveis, localização, estado de conservação, materiais, tipologia arquitetônica, uso, propriedade, data de construção, fotos, entre outras informações que posteriormente passaram a fazer parte dos inventários de bens tombados. Fonseca também critica a prevalência do valor estético e a pouca importância dada ao valor histórico neste período. Todas essas características podem ser observadas na gestão do patrimônio tiradentino nas décadas de 30, 40, 50 e 60.

Na segunda fase, descrita por Sant'Anna (1995) como Cidades Históricas e o Desenvolvimento Regional, começa-se a discutir a inclusão da população nos processos 
decisórios. Nesse período o Brasil se torna membro do ICCROM e do ICOMOS e participa da Convenção do Patrimônio Mundial. O compromisso de Brasília (1970) e de Salvador (1971) criam os órgãos municipais e estaduais de patrimônio, descentralizando a gestão - O Instituto Estadual do Patrimônio Histórico e Artístico de Minas Gerais (IEPHA-MG) foi criado nesse momento - 1971 .

O turismo vai ganhando cada vez mais espaço nas discussões sobre o patrimônio nessa fase que dura um pouco mais que uma década. Um marco importante, neste sentido, é a criação do Programa de Cidades Históricas $(\mathrm{PCH})$ em 1973 visando a rentabilidade econômica através do turismo (MELO, 1998:28). É no final dessa fase que, em Tiradentes, será ensaiado o "desenvolvimento regional" através do Plano da Fundação João Pinheiro para o Circuito Turístico Campo das Vertentes - que incluía Tiradentes ${ }^{21}$.

Ainda nesta fase, em 1975, o Conselho da Europa se reúne para discutir e consolidar as práticas e experiências de restauração urbanística aplicadas recentemente no continente. Da Europa o tema se expande para o mundo em 1976, com a Conferência de Nairóbi da UNESCO

onde são produzidas recomendações relativas à salvaguardados conjuntos históricos e tradicionais e seu papel na vida contemporânea, que além de reafirmarem os valores desses conjuntos, advertem quanto aos riscos de banalização e normatização provocados pela cultura de massas e pelos processos de globalização. (MENICONI, 1998:56)

O que marca a passagem do segundo para o terceiro momento (1979) é a criação da Fundação Nacional Pró-Memória por Aloísio Magalhães. Essa fase vai ser chamada pela autora de Cidade Documento e o Tombamento como Instrumento de Política Urbana. A visão de que a população, antes distante, agora é a principal guardiã de seus bens é uma das fortes

\footnotetext{
${ }^{21}$ Após uma reestruturação nos Circuitos Turísticos (instância de governança regional criado pelo Plano de Estadual de Regionalização do Turismo) Tiradentes passou a compor o Circuito Turístico Trilha dos Inconfidentes.
} 
marcas desse período. Arantes Neto (2006:58) destaca a partir do Relatório de Brutdland (1987) sobre sustentabilidade, os princípios da democracia se encontram indissociáveis da valoração e da gestão do patrimônio:

Por essa razão, o modo como se implementam as ações de proteção e salvaguarda, isto é, o modo de relacionamento que se estabelece com a sociedade, é tão importante quanto a qualidade das obras de restauração e reabilitação feitas nas estruturas arquitetônicas e urbanísticas.

Melo (1998:29) ressalta que "pela primeira vez foi tombado um terreiro de candomblé ampliando étnica, religiosa e arquitetonicamente a política de preservação”. Em 1990 a Fundação é substituída pelo Instituto Brasileiro do Patrimônio Cultural (IBPC), vinculado à Secretaria de Cultura da Presidência da República (MELO, 1998:32).

O planejamento, típico do desenvolvimento regional $\left(2^{\mathrm{a}}\right.$ fase $)$ influenciou a transformação do centro histórico de Tiradentes (e do Largo das Forras) em território turístico - que foi, de certa forma, deliberado, como fica claro nas diretrizes do Plano de Desenvolvimento para a Região do Circuito Turístico Campo das Vertentes da Fundação João Pinheiro (1980) e das Normas de Proteção para o Centro Histórico - Plano Piloto Tiradentes do IBPC (1997)

É no início da década de 1980 que, preocupada em aproveitar e impulsionar o incipiente desenvolvimento do turismo na região, a Fundação João Pinheiro desenvolve o Plano de Organização Espacial do Circuito do Ouro e Campo das Vertentes. O Largo das Forras foi um dos espaços que mais recebeu incentivos a intervenções. Segundo o próprio Plano:

Na Praça Berço da Liberdade e na Rua Gabriel Passos, onde há maior índice de edificações comprometedoras, faz-se necessário um trabalho de agenciamento das fachadas. Nesta região algumas construções são altamente conflitantes com o núcleo antigo. (FUNDAÇÃO JOÃO PINHEIRO, 1980:99) 
O Plano propõe que os imóveis mais novos do Largo (lado norte) se adéquem ao estilo dos casarios mais antigos eliminando os afastamentos frontais e laterais:

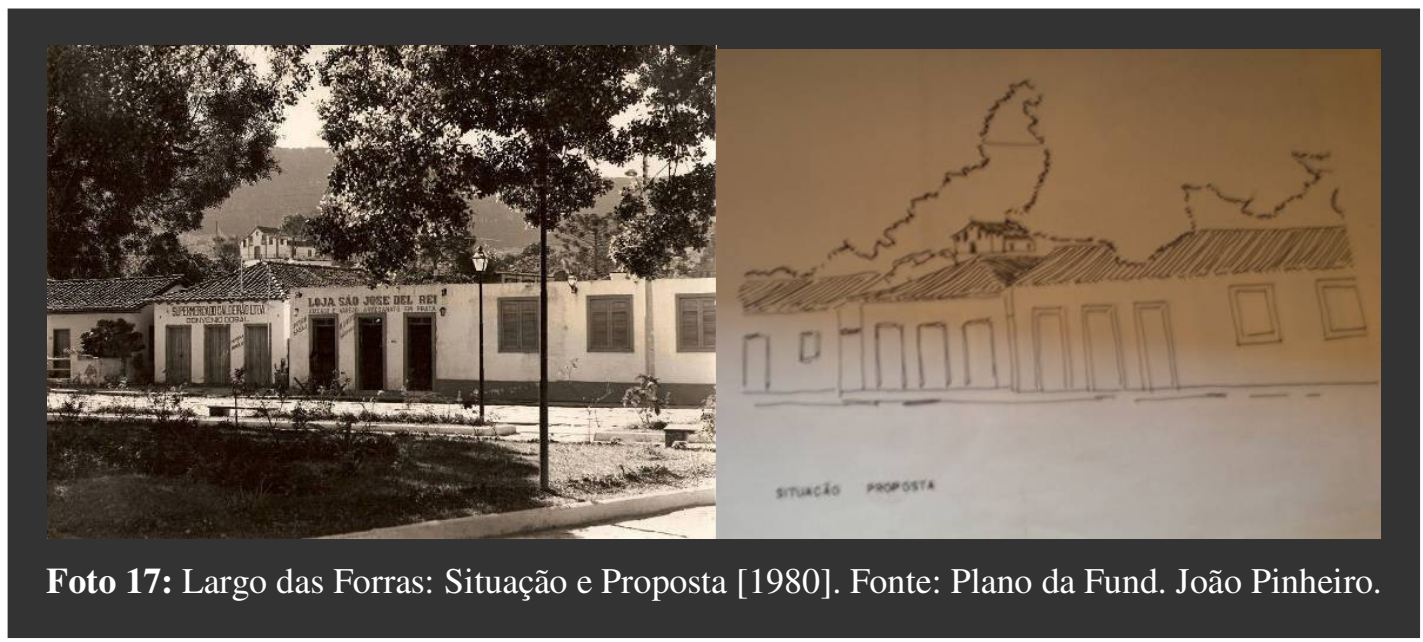

O plano também deixa diretrizes para futuras construções:

\begin{abstract}
Altura máxima permitida para as construções - 1 pavimento, com cobertura em telhas de barro tipo canal, e cumeeiras paralelas ao passeio, apresentando beirais mínimos de $50 \mathrm{~cm}$. Será liberado o uso do porão quando a topografia permitir. Para o exterior do edifício deverá ser usada a caiação ou pintura em tonalidades claras. (FUNDAÇÃO JOÃO PINHEIRO, 1980:83)
\end{abstract}

Nesse plano sugere-se a homogeneização que em outras cidades coloniais mineiras como Ouro Preto, aconteceu na década de 1940. Essa postura reforça a valorização do patrimônio por critérios estéticos. Neste momento, contudo, o fio condutor do plano de intervenções não é mais o resgate da identidade nacional (como era na fase heroica do IPHAN, de concepção do patrimônio como monumento ${ }^{22}$ ), mas a utilização econômica do espaço de memória (concepção do patrimônio como instrumento ${ }^{23}$ ).

${ }^{22} 1^{\mathrm{a}}$ fase de Sant' Anna, 1995.
${ }^{23} 2^{\mathrm{a}}$ fase de Sant'Anna, 1995. 
O paradigma de patrimônio enquanto alavanca para o desenvolvimento econômico se concretizou na carta de Quito:

Partimos do pressuposto de que os monumentos de interesse arqueológico, histórico e artístico constituem também recursos econômicos da mesma forma que as riquezas naturais do país. Consequentemente, as medidas que levam a sua preservação e adequada utilização não só guardam relação com os planos de desenvolvimento, mas fazem ou devem fazer parte deles. (NORMAS DE QUITO, 1967)

Essa nova concepção pode ser resumida na frase de um diretor de museu francês (In: BENHAMOU 2007): "quando não há mais agricultura nem indústria, deve-se fazer o patrimônio cultural dar frutos"; e do ministro da Cultura Francisco Weffort (In: LEITE, 2007:70): “o patrimônio cultural no Brasil não é só uma questão de cultura, mas também matéria econômica".

Segundo Melo (1998:13), no Brasil a absorção e tradução das Normas de Quito (1967) se deu, sobretudo, no Compromisso de Brasília (1970) e no Compromisso de Salvador (1971) que preconizaram “uma valorização desses bens [patrimoniais urbanos] ('mise en valeur' ou 'enhancement'), de modo que se pudessem gerar lucros através do turismo".

O Plano da Fundação João Pinheiro está em grande sintonia com o propósito de transformar o patrimônio em uma forma de geração de renda. Ele aponta como estratégia

(...) a implantação de um programa envolvendo os órgãos estadual e nacional de conservação do patrimônio histórico, no sentido de se processar a restauração simultânea de diversas edificações. Este programa poderia se estender por diversos anos, dando empregos à habitantes locais e assegurando tanto uma dinamização da economia local (pelos empregos gerados e pela conseqüente expansão do turismo face à preservação do conjunto arquitetônico e urbanístico do núcleo), quanto a necessária intervenção para a recuperação do deteriorado patrimônio histórico presente no município. (FUNDAÇÃO JOÃO PINHEIRO, 1980:24)

Essa perspectiva de valorização estética e econômica se confronta com a valorização histórica (também conhecida como documental ou científica), pois sendo o mimetismo visto 
não como 'falso histórico', mas como homogeneização do conjunto, uma necessidade estética, a função documental e cognitiva se perde.

O 'estilo patrimônio' foi a orientação dada às novas construções e, mesmo, à adaptação das construções "inadequadas". Havia, contudo, a diretriz de reconstrução para os casos em que fosse comprovada existência prévia de um imóvel colonial e houvesse fotos, plantas ou qualquer tipo de documento que embasasse essa intervenção. Conforme colocaram Claudia Freire e Lia Mota (2003, In: CERQUEIRA, 2006:318) no artigo "O inventário de bens imóveis em Minas Gerais como instrumento de proteção: caso de Tiradentes", nesta cidade:

face as dimensões do sítio, realizamos prospecções arqueológicas nos espaços urbanos, hoje vazios, para pesquisa sobre remotas utilizações, este procedimento, a principio de um rigor técnico não usual nos trabalhos de preservação no Brasil, despertou maior interesse e curiosidade dos moradores, apresentando um papel didático de suma importância; hoje os proprietários custeiam as despesas da pesquisa arqueológica em seus terrenos, antes de intervirem.

O código de obras da cidade prevê que, em caso de incêndio que atinja imóvel do centro antigo (setor 1 da figura 07), o proprietário "dará ciência do fato ao órgão competente e procederá imediatamente à sua reconstrução".

O inventário de imóveis do IPHAN inclui uma casa "colonial” na Rua Direita n.266 com a informação de que "o imóvel foi reconstruído nesse século depois que a casa que existia no local ruiu" (IBPC, 1997:41). Mesmo sendo uma casa deste século e sendo uma reconstrução, ela consta no inventário como um bem patrimonial.

Choay (2001) nos alerta para o fato de que as reconstruções não são um fenômeno recente, podendo ser identificadas já no ano de 900. Nos tempos modernos os exemplos são inúmeros. A autora nos conta de um arquiteto americano que submeteu à aprovação do congresso 
um projeto para o Museu Nacional de História que nada mais era que a reprodução tecnicamente perfeita de templos da antiguidade.

As réplicas têm sua função de preservação, nos casos em que são construídas para poupar os originais das intempéries ou dos impactos da visitação turística. Exemplo emblemático é a substituição da estátua de David de Michelangelo na Piazza della Signoria em Florença por uma réplica idêntica para que a original fosse preservada (atualmente podendo ser visitada na Accademia di Belle Arte) e, ao mesmo tempo, a praça não fosse "mutilada" com sua retirada. Esse tipo de proposta ainda causa polêmica e indefinição em Congonhas-MG, onde os 12 profetas esculpidos por Aleijadinho na entrada da Igreja de Bom Jesus do Matozinhos (conjunto considerado pela UNESCO patrimônio mundial) encontram-se degradados principalmente pelas ação das chuvas (bastante ácidas na região), pombos e visitantes.

A reconstrução também pode ser uma forma de preservação através da manutenção do savoir-faire, das técnicas construtivas/modos de fazer. Para a cultura japonesa, por exemplo, a preservação da técnica é muito mais importante que o patrimônio material em si. Percebe-se, portanto que o conceito e os valores do patrimônio não são universais. A globalização contribui para que os diversos conceitos e valores se propagem, mas isso não significa uma evolução em direção a um consenso, muito pelo contrário, abre mais possibilidades de fragmentação e criação de grupos de defesa de um valor específico.

De forma análoga, a dimensão simbólica pode ser considerada a que mais importa em casos como a Igreja Santo Sepulcro em Jerusalém cuja "autenticidade de monumento não consiste nem nas formas exatas nem em materiais definidos [visto que um protótipo da original], mas na dimensão simbólica conferida pela associação de traços imateriais e alguns traços materiais". (CHOAY, 1995:12)

Jokilehto (1985) acredita que a reconstrução, em casos que ele considera excessivos, causa grandes perdas. $\mathrm{O}$ autor apresenta casos como o de uma cidade da Noruega que teve parte dos 
imóveis históricos reconstruídos e, posteriormente, ignorados pela UNESCO que os excluiu da área determinada como patrimônio mundial. Mas no caso de Varsóvia, por outro lado, a UNESCO considerou as reconstruções como patrimônio válido visto que, especificamente nessa cidade, $85 \%$ do patrimônio foi destruído na II Guerra Mundial e que, além de um profissionalismo exemplar e fidelidade na reconstrução dos imóveis, houve como determinante o fato de que eles voltaram a exercer o papel que tinham na sociedade antes da guerra, carregando consigo toda uma apropriação e uma memória pré-guerra enriquecida com o episódio de sua destruição e reconstrução para a cidade.

Para Hennig (2007:99) “o valor histórico é relativo à materialidade do bem, à sua passagem pelo tempo, impossíveis de serem emulados - não existe no objeto réplica o valor de ancianidade de Riegl, ou a reverência de Ruskin." Para a autora, "trata-se apenas da emulação de estilos, objetos e estruturas 'à moda antiga', as quais, em sua aparência fresca não convencem e não se equiparam aos objetos originais". Já a posição de Choay (1995:105) em relação à reconstrução é categórica. A autora afirma que "toda reconstrução é por definição condenada à inautenticidade, pois ela não pode se apropriar do estado civil daquilo que ela reproduz: cópia, interpretação ou invocação, ela pode somente dar a conhecer ou autenticar seu estatuto de falso, de réplica ou de lembrete".

Meniconi (1998:57), por outro lado, acredita que "a sacralização dos objetos, as exigências de autenticidade absoluta revelam um certo fetichismo pela matéria e representam reverberações da postura ruskiana, que aplicada ao caso das cidade, remete a um romantismo carregado de moralismo".

Na teoria crítica de Brandi a autenticidade é relativizada na medida em que não é mais inerente ao objeto, mas depende da intencionalidade de duplicidade do seu autor, ou seja, a autenticidade ou falsificação está presente no juízo da criação. Brandi acredita, ainda, que mesmo as cópias são uma forma de expressão cultural de seus tempos ao afirmar que 
a cópia, a imitação e a falsificação espelharão a fácies cultural do momento em que foram executadas e, nesse sentido, desfrutarão de uma historicidade que poderia se dizer dúplice pelo fato de terem sido concretizadas em um determinado tempo, e pelo fato de portarem consigo, inadvertidamente, o testemunho das predileções, do gosto e da moda daquele tempo (BRANDI, 2004:117)

Do ponto de vista da autenticidade apenas material (construções originais) é contestável a classificação de "cidade colonial" a um espaço que, segundo Pellegrini Filho (2000:35) baseado no censo de 2000, 130 das 1.622 edificações são setecentistas, o que corresponde a apenas $8 \%$ das construções.

No Largo das Forras é difícil datar com precisão todos os bens imóveis, pois não há documentação disponível para as construções mais antigas. Em relação aos imóveis antigos há datação precisa apenas da Capela de Bom Jesus da Pobreza (1782) e da Capela do Passo (1807). Há relatos e indícios de que o casarão da prefeitura (N.1 na figura 05) seja setecentista, mas não foram encontrados registros. Da mesma forma, estima-se que a maior parte das construções da Rua Resende Costa (ou Rua das Forras) seja do século XIX: a construção onde funciona o Hotel Ponta do Morro (era um sobrado e de original hoje, só tem a parte térrea da fachada), a Pousada do Largo (só se manteve a fachada que foi alterada e reconstituída por ordem do IPHAN), os imóveis onde funciona a Chocolateria Cacau Show e a boutique Brazil Coast $-\mathrm{N}^{\mathrm{os}} 18$ e 19 na figura 05 .

Sabe-se apenas que o sobrado onde funciona o Hotel Mãe D’Água (1971 com alterações em 1994) é uma construção nova que substitui a casa de Eliseu Veloso que ruiu na década de 1940 e que os imóveis de Francisco Lourenço (restaurante, loteria e farmácia) na esquina do Largo próximo à Capela, são construções apontadas na figura como "ocupação recente" segundo o inventário do IBPC (1997) - mas não foi encontrada a autorização de construção ou modificação dessas construções no IPHAN. 
Registros dos outros imóveis recentes foram encontrados. Foi possível ter acesso à autorização do IPHAN para a construção do primeiro andar do prédio onde funciona o Bêta da Prata, datada de 1974, e a autorização de construção do seu segundo andar, de 1978. Também foram encontrados registros da construção do anexo da casa dos Barbosas (que foi o correio de Francisco Barbosa e hoje é a Oficina de Ourivres) ${ }^{24}$ e da autorização de modificações não especificadas na casa de Francisco Barbosa em 1957. Em 1969 é autorizada no IPHAN a construção do segundo andar, transformando no "sobrado Barbosa" o que até então era uma casa de apenas um pavimento em estilo art decò. Há ainda duas outras autorizações de reforma não especificadas em 1970 e 1978 para esse imóvel.

A ocupação do lado norte do Largo, como já foi detalhada, ocorreu após 1960, tendo um formato próximo do atual se consolidado no final da década de 1970.

Próximo à prefeitura, onde hoje é a Associação dos Artesãos (desde 1998) era garagem da prefeitura na década de 1980 e, antes disso, terreno baldio $-\mathrm{N}^{\mathrm{0}} 2$ na figura 05 . A lojinha de artesanato (Magno Móveis) e o restaurante (Sapore de Itália) ao lado da Associação ocupam o espaço deixado pelo posto de gasolina, que migrou para a entrada da cidade em 1995. Antes da construção do posto (1968) era um terreno baldio.

Apesar das datas não serem muito exatas, usando as informações e estimativas encontradas e classificando por séculos, podemos visualizar na figura $05^{25}$ que aproximadamente $10 \%$ das construções são setecentistas, um pouco mais de $20 \%$ oitocentistas e quase 70\%, a grande maioria, são intervenções do século XX.

\footnotetext{
${ }^{24}$ Há relatos de que havia uma outra casa onde hoje é a oficina de Ourivres que teria pertencido a Gonçalo Joaquim de Barros, um dos primeiros habitantes do local, e que a Capela de Bom Jesus Agonizante (nome anterior ao atual Bom Jesus da Pobreza) teria sido construída como um anexo de sua residência em 1789.

${ }^{25}$ Considera-se o Largo como início do séc. XX, pois foi o momento em que ele ganhou as feições de praça que mantem até os dias de hoje. Os lotes listrados indicam imóveis construídos em um período, mas significativamente alterados (externamente, pois não é possível ter informações precisas sobre originalidade e alterações dos interiores) em outro período.
} 


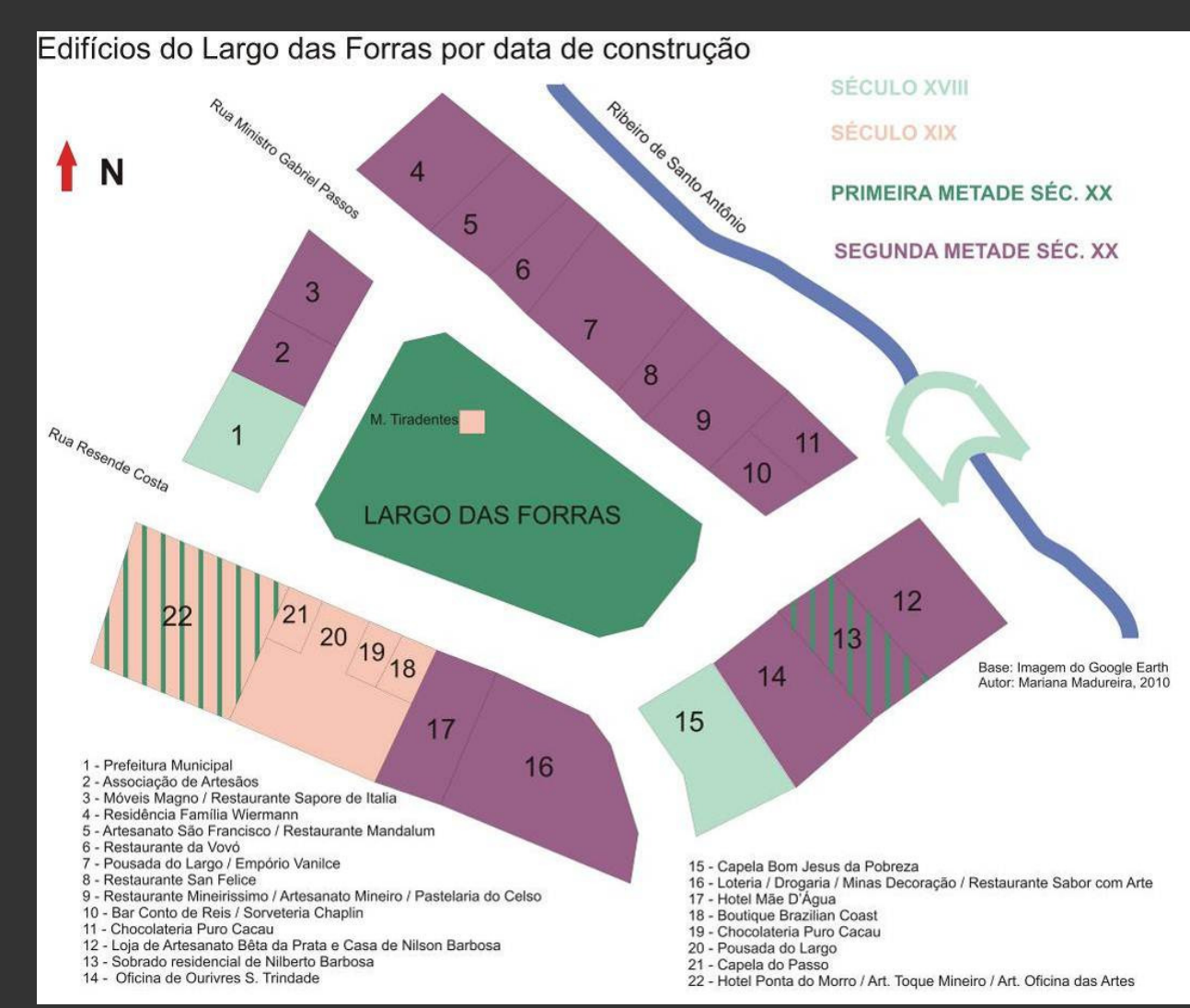

Figura 05 - Idade dos edifícios do Largo das Forras. Fonte: Ilustração da autora (2010).

Como interpretar edificações do século XX miméticas às coloniais? Pode-se denominar de setecentista um espaço que possui quase $70 \%$ dos seus edifícios do século XX?

Mesmo quando falamos de autenticidade puramente material, isto é, edificações (ou partes delas) originais, lidamos com o grande relativismo do termo "autenticidade". MacCannell (1976:155) faz uma comparação cômica ao afirmar que "os Estados Unidos fazem com que o resto do mundo pareça autêntico; a Califórnia faz com que o resto dos Estados Unidos pareça autêntico". É muito complexo tachar um espaço de autêntico ou inautêntico, ainda que seja apenas em termos da originalidade dos materiais. Compará-los enquanto mais ou menos autênticos que outros espaços parece uma solução mais fácil, ainda que perigosa. De forma análoga à comparação de MacCannell poderíamos dizer que o norte 
do Largo das Forras faz o sul parecer autêntico e que, por sua vez, o Largo das Forras faz o centro histórico de Tiradentes parecer autêntico.

Mas é preciso considerar que não necessariamente o material é o mais importante em uma obra de arte ou um bem considerado patrimônio pela sua estética ou pelo seu poder de rememoração. Essa concepção ruskiana é contestada por outras visões como a de valorização do savoir-faire pelos orientais ou do estilo completo por Le Duc. Particularmente interessante para o nosso estudo de caso é a diferenciação que Cesari Brandi (2004) faz entre estrutura (material) e aspecto (imagem) de uma obra de arte. Segundo o autor a primeira pode sofrer quantos ajustes e restauros se fizerem necessários para a preservação desse último - o aspecto. Brandi defende, por isso, que toda intervenção de restauro seja um ato crítico, o que Bonelli (1995) chamou de um "ato de cultura". A forma como se dará a intervenção dependerá, segundo Bradi, da interpretação da obra de arte enquanto obra de arte, que superaria seu significado enquanto obra construída no passado, incorporando valores que se acumularam e, principalmente, o "valor da atualidade".

O valor da atualidade de Brandi é um conceito próximo do que Riegl denominou kunstwollen, que significa algo como "vontade da arte" que em uma determinada época e local é diferente de outra. Ou seja, o paradigma , o contexto, os valores vão determinar o que é arte e o que não é, o que tem valor e o que não tem, variando geográfica e temporalmente. Brandi acredita que todo bem patrimonial enquanto obra de arte é recriado toda vez que ocorre nova fruição - e essa recriação depende de cada expectador e de sua "vontade da arte". Argan (1998:25) também defende que os obras de arte possuem, antes de mais nada, um valor de contemporaneidade (Gegenwartswerte de Riegl)

Qualquer que seja uma antiguidade, a obra de arte sempre ocorre como algo que acontece no presente (...). Diante [dela] não podemos nos omitir e pronunciar juizos serenos e distantes, devemos decidir se prestamos ou não atenção, aceitamos ou recusamos. E o que se aceita ou se recusa é, na realidade, a coexistência com a obra, a qual está fisicamente presente e, apesar de pertencer ao passado, ocupa uma porção do nosso espaço e do 
nosso tempo reais. (...) Se lhe reconhecemos um valor, devemos inserí-lo e justificá-lo em nosso sistema de valores; caso contrário, devemos nos livrar dele, fingindoque não o vemos, removê-lo ou, mesmo (como muitas vezes aconteceu e acontece) destruí-lo.

Para nossa época a arquitetura colonial significa arte e assume grande valor. Prova disso são os milhares de turistas (nacionais e estrangeiros) que visitam todos os anos o Pelourinho em Salvador, Ouro Preto, Recife, dentre outras cidades cuja arquiteura representa esse período.

Nesse sentido, a atual "vontade da arte" defende que estética colonial seja preservada em Tiradentes. Sobretudo porque Tiradentes muito mais que material ou estrutura (visto que apenas $8 \%$ do casario é setecentista) é aspecto - IMAGEM.

Para Brandi um bem patrimonial tem 3 momentos distintos: o de sua criação (passado), o intervalo (da sua criação ao presente), e o momento da sua fruição (presente). Se a intervenção interfere diretamente na essência da obra isso significa intervir no momento 1 , da criação, o que seria para Brandi uma heresia - uma intromissão na obra criativa do autor uma crítica a Le Duc e o que ele chama de 'restauro de fantasia'. Tentar resgatá-lo tal como era em sua criação (com'era dov'era) é ignorar todo o segundo momento (intervalo) que retrata o percurso de um bem - seria destruir o que Ruskin chama de "pátina do tempo". Restaria ao nosso tempo, portanto, intervir no bem apenas no momento presente, possibilitando a fruição atual da melhor forma possível. Se o bem é, contudo, a imagem da cidade colonial, restaria ao nosso tempo apenas mantê-la. Ainda que essa "manutenção" (que envolve uma constante re-criação) possa ser contestada, ela própria é histórica na medida em que relata seu processo de construção.

No caso do Largo das Forras houve adaptação de imóveis antigos para as necessidades atuais (como na restruturação interna da Prefeitura) e aproveitameto apenas de fachada (como 
no Hotel Ponta do Morro) - intervenções drásticas, mas amplamente aceitas como forma de viabilizar o uso e, com ele, a preservação.

Foram poucas as intervenções em bens antigos, já que a maioria são construções recentes, como vimos na figura 05 . Voltaríamos, então, à questão do preechimento dos vazios - optando por interpretar de forma brandiana e reconhecendo o conjunto como a obra de arte, pode-se aceitar as novas construções miméticas. As homogeneizações sugeridas em construções ecléticas e art decò do século XX poderiam ser consideradas, contudo, não uma forma de preenchimento de vazio, mas uma forma de "arquitetura de fantasia" que anularia uma forma orgânica anterior? Essa discussão ainda está em um estágio frágil, já que não há consenso ou teoria concreta que permita identificar quando uma "correção" é recomendável (como o IPHAN faz ao obrigar proprietários de imóveis que interviram sem autorização a "retormar o estágio anterior") ou é o que Brandi chamaria de "intromissão na obra criativa do autor" (apagando uma fato histórico pois, ainda que esse fato seja pejorativamente identificado como descaracterização, ele reflete uma nova necessidade, estética ou ideologia).

Segundo Olinto Santos, responsável pelo IPHAN local, o Plano da Fundação João Pinheiro acabou não sendo seguido à risca, pois não chegou ao conhecimento dos proprietários e não caberia ao poder público, nesse momento, intervir em imóveis particulares. Várias intervenções não autorizadas pelo IPHAN foram realizadas nas últimas décadas e algumas delas ainda estão na justiça, como é o caso da fachada da Pousada do Largo no norte da Praça e dos acréscimos no Restaurante da Vovó.

Em 1981 houve uma reforma na praça com projeto do renomado paisagista Burle Marx (doado por influência da presidente da Fundação Rodrigo Melo Fraco de Andrade, Maria do Carmo Nabuco), apoiado por diagnóstico da arquiteta Lia Motta (então técnica do IPHAN), com levantamentos altimétricos da Fundação João Pinheiro e recursos da Embratur, que nessa época assumia o papel executivo de um ministério do turismo que ainda não existia 
(FROTA, 2005:133). Pellegrini Filho (2000:67) critica o projeto argumentando que "discutese, todavia, a validade de um tratamento de paisagem urbana segundo uma estética moderna, destoando de todo contexto colonial da cidade". Contudo, deve-se considerar que a estética é sempre a do momento presente à intervenção, é sempre a influência do kunstwollen da época. Seria possível aplicar os conceitos do urbanismo colonial para reforma da praça, mas isso significaria retomá-la enquanto largo sem ajardinamento, mobiliários e monumentos. Essa atitude desagradaria plenamente a "vontade da arte" e as necessidades de uso da atualidade.

O formato proposto pelo paisagista Burle Marx é bem semelhante ao que permanece até os dias de hoje.




Durante a década de 1990 várias modificações ocorreram no Largo. Em 1994 o Restaurante de Mitula se tornou Hotel Mãe D’Água. Em 1995 o posto de gasolina mudou-se para a entrada da cidade e deu lugar a um restaurante e uma loja de artesanato. Apesar de não possuir volumetria e afastamentos condizentes com o conjunto, as obras foram aprovadas pelo IPHAN por manter a base das construções do posto de gasolina de 1968. Essa postura do IPHAN demonstra um abandono ao impulso de homogeneização e respeito à história recente, buscando, todavia, harmonia nas cores e em alguns materiais.



Em 1998 a garagem da prefeitura tornou-se galpão da Associação de Artesãos e Vanilce Barbosa abriu a Pousada do Largo num terreno comprado de Miltinho ao lado do Passo. O galpão é uma construção nova em "estilo patrimônio", sendo fácil de identificar como obra mais recente pelas proporções, enquanto a Pousada não possui registros sobre a data da construção original e as modificações realizadas - mas estima-se que seja do século XIX. 
A Proposta de critérios e normas de proteção para o sítio histórico de Tiradentes do IPHAN (1994:41) considera o Largo das Forras dentro do setor 1 (área histórica) ${ }^{26}$, reconhecendo, no entanto, que se trata de uma área considerada histórica enquanto imagem, mas não representativa do Brasil colônia enquanto arquitetura original

Este setor compreende o traçado urbano tradicional, ou seja, os principais eixos de consolidação do núcleo setecentista de Tiradentes, onde se concentram as edificações mais antigas. É, portanto, historicamente, a área mais densamente ocupada que, na sua relação com a paisagem natural, tornou-se responsável pela série de atividades locais, sócio-econômicas e culturais, principalmente ligadas ao turismo. O Largo das Forras, embora adensado nos últimos 30 anos, foi incluído nesse setor por já ter-se incorporado à imagem tradicional do sítio histórico. Representa na cidade a marca da ocupação dirigida pela intervenção do órgão nacional de preservação que, diferentemente do que se faz hoje, recomendou durante muito tempo a reprodução de características arquitetônicas setecentistas como forma de preservação. (grifo nosso)

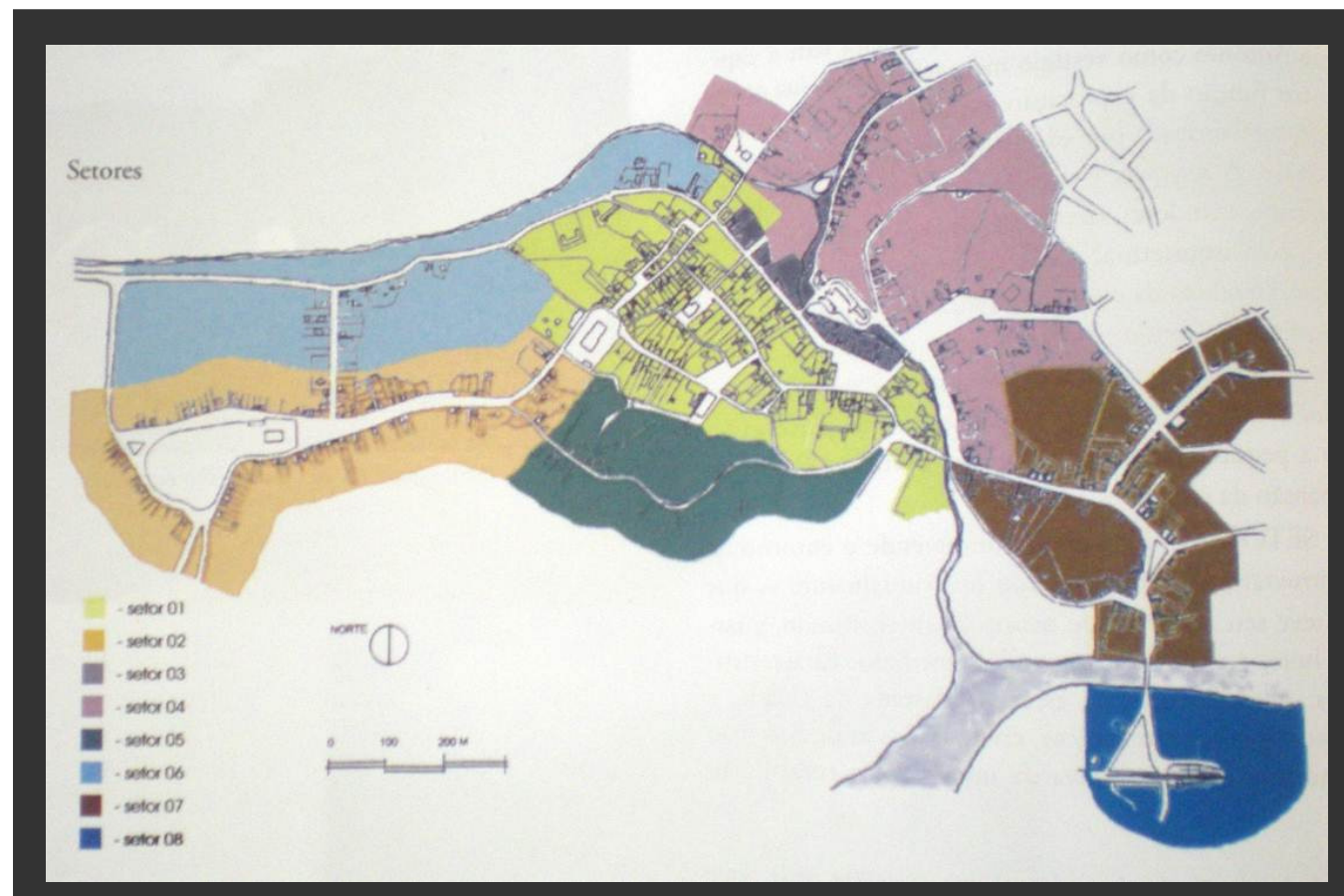

Figua 07: Zoneamento da Área de Proteção. Fonte: IBPC, 1997.

\footnotetext{
${ }^{26}$ A parte norte do Largo está no setor 3 que é uma área definida por uma ocupação mais recente dentro do centro antigo. Essa área foi ocupada tardiamente, principalmente por estar às margens do Ribeiro de Santo Antônio e ter estado sujeita a inundações no início da ocupação.
} 
Esse plano demonstra claramente a mudança de postura do IPHAN que destaca que a cidade deve ser vista como

um documento de história urbana para além das características estéticasestilísticas de sua arquitetura, cuja leitura deve ser feita através das marcas impressas no espaço urbano, que configuram um conjunto de significados a serem permanentemente recodificados e utilizados como referência básica no trabalho de preservação (IBPC, 1994:05)

Como colocou Isabel Câmara em sua monografia sobre a preservação do centro urbano de Tiradentes pelo IPHAN:

Com o desenvolvimento e consequente crescimento urbano destes sítios tombados, o IPHAN foi tendo que ampliar o conceito de preservação, antes mais voltados para os valores arquitetônicos e fachadistas, passando a se preocupar também com a preservação urbana, da casa e da rua, da área urbana como entorno paisagístico e das diversas manifestações culturais, consideradas bens intangíveis. (2000:06 In: CERQUEIRA, 2006:367)

As regras hoje são mais bem definidas, o que facilita a fiscalização. Há ainda grande dificuldade em fazer a população aceita-las (talvez porque não tenha sido dada à mesma a possibilidade de conhecê-las em profundidade e compreender sua lógica) como fica claro nos vários processos que o IPHAN tem em aberto na justiça contra proprietários que fizeram alterações sem autorização. A postura severa do IPHAN desencadeou o surgimento de um grupo de oposição, que se instalou, paradoxalmente, no órgão que deveria ser seu grande parceiro em todas as ações - o Conselho de Preservação Patrimonial e Ambiental. Essa "rixa" fica clara no ofício que Isabel Braga da Câmara (responsável pelo IPHAN local na época 1996), manda a sua superior Cláudia Lage:

Soubemos que se tratava de mais uma reunião do "Conselho de Preservação Patrimonial e Ambiental" criado por essa Câmara Municipal. Intencionalmente o IPHAN não foi convidado, pois este evento faz parte do movimento ACORDA TIRADENTES, dirigido por este Conselho para contestar o trabalho da Instituição na cidade. Vale a pena esclarecer que os integrantes desse grupo são, na maioria, pessoas que no momento estão 
sofrendo ação judicial impetrada pelo IPHAN, não tendo o Instituto Histórico Geográfico de Tiradentes (IHGT) e a Sociedade Amigos de Tiradentes (SAT) aceitado em participar do Conselho por considerarem os integrantes não afeitos a causa da preservação, conforme informação do Secretário Municipal de Turismo e Meio Ambiente e Diretor de Patrimônio da SAT, Sr. Luiz Cruz. (In: CERQUEIRA, 2006:303)

A Prefeitura Municipal, na contramão do IPHAN, se mostra condescendente:

Para as edificações não serem descaracterizadas, seguem as normas do IPHAN, que dividiu a cidade em 8 setores. Quando o morador faz alguma reforma ilegal, aí a prefeitura adota medidas compensatórias em que realiza serviços de melhoria do patrimônio, como melhoria em forro de igreja, ao invés de aplicar multas (Karine Oliveira em entrevista a Lima, 2008:267)

A atuação da Prefeitura de Tiradentes na preservação do patrimônio tem ocorrido de forma esporádica e reativa, como admitiu o próprio prefeito, Nilzio Barbosa (In: LIMA, 2008:268): “o ICMS Cultural vem incorporado no ICMS do município. Deveria vir separado para facilitar sua aplicação. O patrimônio é atendido por necessidade, não existe um planejamento ou uma porcentagem voltada para isso".

Esse conflito de posturas fica bem descrito em parecer que Isabel Câmara do IPHAN local encaminha ao escritório geral em 1998:

O relacionamento do IPHAN com a prefeitura podemos dizer que é cordial, não existindo atrito, mas também muita dificuldade para um trabalho conjunto, dada a falta de equipe técnica nas duas instituições e o lado não comprometedor da Prefeitura, que busca agradar a todos, deixando o desgaste político apenas por parte do IPHAN. (In: CERQUEIRA, 2006:304)

Em relação à população, grande parte ainda se mantem apática. Há contudo, grupos interessados e atuantes como os membros do IHGT, SAT, Conselho Patrimonial, vereadores da Câmara e alguns empreendedores. Em ofício ao IPHAN o vereador Geraldo Fonseca contesta a pouca participação popular na definição dos critérios de intervenção no centro histórico de Tiradentes elaborados pelo IBPC a partir de 1994. 
(...) questionei em reunião sobre esses critérios, conforme ofício em anexo. Enviei o parecer da Câmara Municipal e ao Escritório Técnico local do IPHAN, Coordenação Regional e Presidência, onde recebi resposta do presidente do IPHAN Sr. Glauco Campelo, não convincente e nem coerente com o que aconteceu realmente, quando diz que os critérios adotados para a cidade de Tiradentes são resultados dos estudos técnicos e antes apresentados a comunidade. Não é verdade, pois os técnicos (alguns) já vieram com as normas prontas e apresentaram a comunidade onde através de uma explanação pouco explicativa e um curto espaço de tempo (15 dias) quiseram fazer com que a comunidade as aceitasse. (1996, In: CERQUEIRA, 2006)

Após essa demonstração de descontentamento com a condução dos trabalhos, foi feita uma nova reunião e discussão das normas e diretrizes. Após um ano e meio foi feita nova reunião no Rio de Janeiro com Isabel Câmara (IPHAN local), Lia Mota e outros técnicos. À partir das dificuldades levantadas foram feitas algumas adaptações. A publicação de 1997 é o resultado final de todo esse processo de levantamentos e discussões, iniciado em 1994. Em 1999 ocorreu nova reunião na qual, entre outras medidas, foi atualizado o mapa dos setores (e os mesmos foram descritos em termos de endereços, já que constantemente proprietários de imóveis que se encontravam no limite de dois setores não sabiam a qual pertenciam) e a orientação de imóveis que poderiam seria substituídos foi alterada pela indicação daqueles que, por sua importância histórica ou artística, deverão sser mantidos. O “estilo colonial” está sendo evitado, sendo as considerações do IPHAN em relação ao estilo cada vez menos incisivas:

As transformações foram mutiladoras no sentido de criarem um aspecto 'colonioso' à unidade, o que é visto pela cidade como uma intervenção correta mesmo em imóveis de outros períodos. Ao se indicar as unidades exemplares como elementos arquitetônicos, estamos fazendo um registro histórico do desenvolvimento e da ocupação do sítio urbano como vetores de expansão de Tiradentes e mostrando ainda a vitalidade da cidade em se renovar. (RANGEL, 2000:7 In: CERQUEIRA, 2006:335)

Como podemos ver a política de patrimônio que se aplica hoje é muito mais cautelosa do que as práticas das primeiras décadas seguintes ao tombamento - que não exigiam tantos estudos e discussões. Há, todavia, um longo caminho a ser percorrido até que se atinjam 
condições ideais. Esse percurso possui um valor histórico intrínseco . Como Brandi ressaltou todas as escolhas, por mais que nos pareçam desastrosas em algum momento, são peças fundamentais na construção da história de um bem. Esse acúmulo de histórias construídas pelos paradigmas e crenças de cada período e essa sobreposição e multiplicidade de significados é que poderão dar legitimidade à denominação de um objeto de patrimônio histórico e cultural coletivo.

No caso de cidades essa afirmação se torna ainda mais pertinente, pois enquanto organismo vivo em constante apropriação e fruição, é impossível isolá-las, protege-las como obras de arte em redomas de vidro. A gestão de um centro urbano como patrimônio é, nesse sentido, um grande desafio. Como colocou Simão (2001:96):

(...) [os núcleos urbanos] idealizados pelos modernistas como 'obras de arte', símbolos da identidade nacional, mostraram-se, no correr do tempo, como cidades vivas, que experienciam em sua dinâmica problemas comuns aos demais núcleos urbanos e estabelecem redes de relações que produzem soluções conforme suas especificidades e diversidade.

Nesse sentido, a cidade de Tiradentes vem se desenvolvendo lentamente e criando sua solução própria para as questões duais de preservação e "tabula rasa", tradição e inovação e buscando, dessa forma, seu modelo único e próprio de gestão do patrimônio. 


\section{2 - A TRANSFORMAÇÃO DO LUGAR DE MEMÓRIA EM TERRITÓRIO TURÍSTICO}

Tiradentes, ouro antigo na Igreja Matriz Água pura em chafariz,

Oficinas de arte de prata,

Gente nova buscando ideais Casarões coloniais velhos que a Serra retrata. Tiradentes. Tiradentes.

(Refrão do Hino da Cidade)



O processo de transformação dos espaços guiado, sobretudo, pelo desenvolvimento do turismo ganhou o nome de "turistificação". Knafou (1996) acredita que o processo de turistificação pode ser gerado por 3 diferentes atores: o turista (alocêntricos ${ }^{27}$ ), que na busca

27 Perfil psicográfico do turista (PLOG, 2001): Alocêntrico (extrovertidos, autoconfiantes e curiosos, gostam do novo); Semi-alocêntrico; Mesocêntrico; Semi-psicocêntrico; Psicocêntrico (ansioso, inibido, gosta de segurança, previsibilidade e 
de novas experiências descobre e inicia o processo de turistificação de espaços até então baseados em outros modos de vida; o mercado que na busca de benefícios econômicos estabelece o turismo como atividade capaz de gerar divisas para o local e busca a estruturação e promoção do mesmo; e o Estado (governo municipal/estadual/federal ou autarquias) que através das ferramentas do planejamento insere o turismo como estratégia de desenvolvimento local.

No caso de Tiradentes, segundo os relatos dos entrevistados e o Inventário Turístico Municipal, o processo se iniciou com o surgimento de uma demanda de turismo espontânea e tímida. Após esse processo inicial, houve a influência do governo (através do plano da fundação João Pinheiro e da criação dos eventos) e do mercado (constituído dos novos empreendimentos).

Hoje o turismo é a principal fonte de renda do município. Segundo a prefeitura municipal $^{28}$ :

Tiradentes não vive mais do ouro, das lutas pela liberdade, da tecelagem ou da agropecuária, mas da rica conjugação entre os valores preservados do seu passado e de um presente moldado por novas formas de expressão. Possui, atualmente, algumas indústrias de construção, extração de minerais, madeira, mobiliário e produtos alimentícios; na pecuária, sobressai a criação de bovinos, suínos e galináceos; a agricultura tem como principais produtos o amendoim, o arroz, a cana-de-açúcar, a laranja e o milho. Entretanto é o turismo que vem contribuindo não só para o pleno desenvolvimento sócioeconômico da região como também para o aprimoramento dos seus serviços.

O turismo no mundo todo, enquanto atividade social, vem crescendo em quantidade de adeptos (turistas) e espaços visitáveis (destinos). Segundo Urry (1990), Donaire (1995) e Palomoque (1997) o turismo segue uma tendência inusitada de "internacionalização" e “interiorização” simultâneas.

conforto). Quando a demanda pelo desenvolvimento do turismo é iniciada pelo próprio turista, isso significa que o mesmo tem um perfil alocêntrico, pois esse tipo de turista não se importa em visitar localidades que não possuam estrutura turística mínima.

${ }^{28}$ Inventário Turístico Municipal, 2009. Pág 29. 
A internacionalização é facilitada pela compressão do tempo e do espaço (HARVEY, 1989), que tornaram os destinos internacionais cada vez mais acessíveis com as inovações tecnológicas nas áreas de transporte e comunicação. Ela é percebida em Tiradentes pelo ainda pequeno, mas crescente, número de visitantes estrangeiros ${ }^{29}$.

A interiorização, por sua vez, tem origens diversas que passam pela necessidade de desenvolvimento econômico de diferentes áreas de um país (como no caso brasileiro) ${ }^{30}$, do desejo de poupar áreas que estão recebendo excesso de turistas ou mesmo investir na mudança da imagem turística alterando o segmento como ocorreu na Espanha (PALOMOQUE, 2007) com transferência dos investimentos em marketing turístico dos balneários urbanos para áreas rurais.

Um problema dos territórios turístico seria sua tendência a homogeneização com outros espaços de lazer, ou banalização como colocou Costa (2008) - seguindo, sobretudo a tendência do benchmarking e de absorção dos valores dos centros emissores. As cidades tendem a copiar "modelos de sucesso" e as intervenções acabam, muitas vezes, sobrepondo ou escondendo o que elas tem de diferente e típico. Isso significa que Tiradentes dentro do imaginário coletivo ficaria cada vez mais próxima de cidades "similares" como Ouro Preto, Diamantina, Congonhas, etc. Para Lynch (1999:07) essa generalização pelo visitante acontece porque "um objeto visto pela primeira vez pode ser identificado e relacionado não pelo fato de ser individualmente familiar, mas por ajustar-se a um estereótipo já criado pelo observador".

Em Tiradentes essa tendência fica explicita na fala de Lima (2008:261) que afirma que, ao contrário dos destinos que estão valorizando os aspectos locais, a cidade está tendendo

\footnotetext{
${ }^{29}$ Segundo as pesquisas de LeSann os turistas estrangeiros eram $2 \%$ do total de visitantes em 2007. Não há pesquisas esporádicas de demanda na cidade, mas a prefeitura municipal afirma que o número de turistas, de uma forma geral, e o número de turistas estrangeiros, especificamente, vem aumentando. Segundo pesquisa da Secretaria de Turismo realizada em 2005 (In: Campos, 2006:20) 62\% dos turistas estrangeiros são oriundos da Europa, $34 \%$ do continente americano e apenas $2 \%$ da Asia e $2 \%$ da Africa.

${ }^{30}$ O Plano de Estruturação dos 65 Destinos Indutores (2008) implementado pelo Ministério do Turismo coloca como diretriz que todo o estado da federação tenha pelo menos 1 destino indutor (nos casos em que o estado tem um turismo muito pouco estruturado escolheu-se apenas 1 destino - a capital) para melhor distribuição dos benefícios econômicos do turismo pelo país.
} 
a "valorização de uma cultura estrangeira e a tentativa de assemelhar a imagem da cidade com cenários históricos que remetem a cidades europeias, com seus cafés espalhados em praças públicas, cardápios com preços elevados, lojas de Belo Horizonte, artesanatos ‘industrializados', pousadas e hotéis de estrangeiros”.

Um efeito perverso dessa tentativa de se ajustar a padrões externos (e, consequentemente, se homogeneizar com os demais) é a perda do que Harvey (2005) chama da de "renda monopolística", que seria o valor de sua unicidade. Quanto mais comum se torna um destino, menos procurado será pelo público que pode pagar pela distinção. Ele tende a se tornar, nesses casos, um destino de turismo de massa para suprir com quantidade a renda que não consegue mais aferir através da qualidade. Isso ocorre porque o diferencial cultural entra em risco sempre que um lugar de memória é transformado em produto para ser vendido em escala - processo que Harvey (1989) chama de "indústria da herança". Com o diferencial cultural em contestação, sua estabilidade econômica também entra em risco.

As sociedades modernas [e seus espaços] necessitam ao mesmo tempo da divulgação - ampliar o mercado e o consumo de bens para aumentar a margem de lucro - e da distinção - que, para enfrentar os efeitos massificadores da divulgação recria os signos que diferenciam os setores hegemônicos. (CANCLINE, 1997:37)

Para maior parte dos turistas modernos o turismo representa uma fuga do cotidiano, concomitante a uma busca pelo passado, pelas raízes, pela tradição, pela tranqüilidade, rusticidade e simplicidade, entre outros atributos que a vida nos grandes centros já não pode oferecer (KRIPPENDORF, 1989). Nesse sentido, Cohen (1988:376) afirma que a busca por autenticidade (aqui se referindo à autenticidade da experiência turística, isto é, o grau de "verdade" encontrado no destino e no que ele oferece como atrativo) pode variar em 
intensidade de acordo com o grau de distanciamento da modernidade que cada indivíduo busca $^{31}$.

Segundo Rogério Leite (2007:70), apesar de ter várias características em comum, os bens culturais apropriados pela indústria cultural e os centros urbanos que adotaram práticas de gentrification têm uma diferença crucial, que já prevê o problema da queda da renda monopolística dos lugares:

A indústria cultural opera ideologicamente com a idéia de estandardização das mercadorias culturais, pensadas no contexto da acumulação fordista do capitalismo monopolista, tendo como alvo um público consumidor indistinto. A idéia da produção em série é sua característica básica (...). Embora a gentrification possa resultar igualmente em paisagens urbanas estandardizadas, que poderiam ser consumidas por quaisquer pessoas, a lógica da intervenção não se baseia na indistinção de mercadorias voltadas para as massas. Pensada no contexto da acumulação flexível, a construção de singularidade atua na diferenciação e elitização dos espaços urbanos, cujos consumidores, ao contrário das massas, são apenas uma parcela restrita e diferenciada da população.

Leite (2007:67) afirma que Baudrillard (1984) e Bourdieu (1999) explicam essa tendência explicitando "tanto o caráter simbólico das trocas, quanto o caráter econômico da cultura."

Como conseqüência da modernidade vão sendo criados espaços destituídos das características de lugar. O oposto de um lugar de memória (discutidos no início do capítulo 1) seria o não-lugar. Eles se diferem pela historicidade, pela sua capacidade de representar seu próprio percurso ao longo do tempo. Enquanto o lugar de memória conta uma história (ainda que essa seja uma seleção), o não-lugar, segundo Augè (1994) é um espaço de passagem, um espaço incapaz de dar forma a identidade de um grupo.

31 Nesse sentido, Cohen os classifica como Existencial Tourists (que tende a abandonar a modernidade em suas visitas e abraçar completamente o "outro", buscando as experiência mais autenticas possíveis), Political Pilgrims (que idealiza o destino e busca o mais genuíno dentre tudo que é apresentado), Experimental Tourist (participa vigorosamente da experiência ofertada, mas tende a questionar levemente sua autenticidade), Recreational Tourists (aceitam a experiência como autêntica pela diversão, ainda que, no fundo, não acreditem nela) e por último o Diversionary (que não tem ligação, preocupação, ou mesmo conhecimento do conceito de autenticidade). 
Para exemplificar um não-lugar, é elucidativo o exemplo apresentado por Gonçalves (1988) da Colonial Williamsburg, em Virgínia, nos Estados Unidos. Com a finalidade de resgatar a identidade nacional, o reverendo William Archer patrocinado por Rockfeller na década de 1920 decidiu reconstruir a cidade como ela era no século XVIII. Todas as transformações do século XIX e dos primeiros anos do século XX foram destruídas e as formas que a cidade supostamente teria, foram retomadas. É considerado um dos maiores exemplos de disneyficação do patrimônio, uma vez que 616 edifícios pós 1775 foram destruídos, 341 réplicas construídas e apenas 82 edifícios restaurados. Além disso,

a recriação não atinge apenas os prédios, as ruas e os objetos. Ela assume também um aspecto dramático na reencenação, por uma grande equipe de atores, do cotidiano de Williamsburg no século XVIII e mais precisamente no ano de 1775. Esses atores vestem-se tal como homens e mulheres supostamente vestiam-se naquela época, realizam atividades econômicas e sociais daquele período e falam um inglês tal como era supostamente falado naquele século. Movimentam-se com naturalidade pelas ruas e prédios da cidade e fingem ignorar a presença dos visitantes. Ao serem abordados, não saem do seu papel e conduzem-se rigorosamente de acordo com o personagem que estejam representando.

Esse processo de recriação do espaço gerou um não-lugar, um espaço destituído de significado, com apropriação volátil ${ }^{32}$ : as visitações turísticas.

Em caso de não-lugares construídos já com a finalidade de consumo (resorts e shoppings) talvez o impacto seja menor, uma vez que diferente dos lugares turísticos neogênicos (onde a ocupação ocorre em decorrência do turismo), os locais arqueogênicos (anteriores à atividade) possuem toda uma infra-estrutura, um sistema econômico e um modo de vida até então independentes do turismo (FÚSTER, 1975). É nestes locais que a atividade turística se torna mais impactante, pois além das modificações no meio físico há um meio social e cultural suscetíveis a interferências.

\footnotetext{
32 As apropriações voláteis são o que Fortuna (1999:39) chama de "identificação circunstancial e efêmera entre os indivíduos [e os monumentos], pois que as relações sociais que se estabelecem por seu intermédio perduram apenas enquanto se puder continuar a consumir o 'objecto'.”
} 
A contemporaneidade é tão surpreendente e veloz que espaços até uma década atrás considerados indubitavelmente não-lugares, ausentes de identidade, história, significado e apropriação contínua, hoje podem se apresentar como importante pontos de encontro inter e intra grupos sociais. Um dos maiores exemplos são os shopping centers que causaram (e ainda hoje em certa medida causam) horror aos urbanistas e têm um papel importante na vida de pessoas que nasceram nesse novo contexto e encontram ali memórias da infância, ponto de encontro com os amigos, espaço de lazer para família, comodidade para atender suas necessidades e segurança - fator decisivo para atração de freqüentadores em grandes centros. Podemos ainda hoje chamar esse espaço de não-lugar?

E poderíamos chamar de não-lugar espaços historicizados que fizeram uma escolha pela artificialidade? Não poderia ser essa escolha apenas parte da história e da memória desse lugar?

O pós-modernismo é, segundo Harvey (1989:45), um sinal do "hedonismo inconsciente do consumismo capitalista". Em relação à construção dos espaços urbanos, o autor acredita que fomos salvos dos ditames modernos, caindo, agora, em ditadura distinta

As torres de vidro, os blocos de concreto e as lajes de aço que pareciam destinadas a dominar todas as paisagens urbanas de Paris a Tóquio e do Rio a Montreal, denunciando todo ornamento como crime, todo individualismo como sentimentalismo e todo romantismo como kitsch, foram progressivamente sendo substituídas por blocos-torre ornamentados, praças medievais e vilas de pesca de imitação, habitações projetadas para as necessidades dos habitantes, fábricas e armazéns renovados e paisagens de toda espécie reabilitadas, tudo em nome da defesa de um ambiente urbano mais satisfatório.

O turismo demanda equipamentos que atendam as necessidades dos visitantes e tende, com isso, a reestruturar a paisagem urbana. Com a tendência global de internacionalização do turismo (e a proliferação dos restaurantes de cozinha internacional e das franquias multinacionais de alimentação e hospedagem), bem como a tendência pós-moderna de “benchmarking”, invenção ou recriação de espaços, a transformação de lugares de memória 
em lugares artificiais (não-lugares?) pela indústria da herança se torna uma ameaça concreta. Tiradentes não foge a essa tendência.

\subsection{APORTAM NOVOS ATORES: OS ETS, AS INSTITUIÇÕES E OS TURISTAS}

Tiradentes nos anos 1970 era uma cidadezinha tranqüila e rústica. Seu casario colonial (ainda que não muito bem conservado), a Serra de São José e todo o verde que ainda a circundava, bem como a simpatia e simplicidade dos tiradentinos transformavam essa cidade no espaço perfeito para uma visita. Ou uma nova vida.

Na década de 1970 começam a chegar à cidade alguns "forasteiros", que serão fundamentais para construção da história recente de Tiradentes. Eles são os ETs, ou extratiradentinos, como a população local os chama.

Os ETs vieram de várias partes, principalmente das capitais mais próximas: Belo Horizonte, São Paulo e Rio de Janeiro. Segundo os relatos de tiradentinos, eram pessoas adultas (maioria entre 35 e 65) com boas condições financeiras e alta escolaridade. Algumas foram atraídas pela tranqüilidade e beleza da cidade (as que buscavam lazer e compraram sua segunda residência), outras pelo potencial de desenvolvimento do turismo (aquelas que investiram em empreendimentos), mas a maior parte buscava as duas coisas simultaneamente.

Dentre os novos moradores estavam artistas plásticos e artesãos (o que deu nova cara e impulso ao artesanato tiradentino, até então praticamente restrito a prata e posteriormente ampliado para madeira e estanho, dentre outros), empreendedores (responsáveis pela abertura 
de lojas, restaurantes e hotéis) e o diretor da Globo Yves Alves (1929-1996) - o principal responsável pela inserção da cidade na mídia.

Esse aporte de ETs se iniciou nos anos 1970, teve seu auge na década de 1980 e 1990 e continua ocorrendo, de forma menos intensa, até os dias de hoje. Vai ocorrendo em Tiradentes uma lenta e progressiva substituição da população. Segundo o levantamento de Campos (2006:156) há hoje menos de 20 famílias originais de Tiradentes na cidade. É importante ressaltar que 20 famílias não significa 20 núcleos unifamiliares (pais e filhos), mas 20 grupos identificados por um sobrenome comum, como é normal referenciar-se em Minas Gerais: a família Campos, a família Barbosa, a família Wiermann, etc. Hélcio Campos (op cit) aponta que

todos os estudiosos da cidade (PELEGRINE FILHO 2000, ARAÚJO 2004, SIQUEIRA 2004, TADINE JUNIOR 2005) apoiados em dados de entidades como o IBGE e a Fundação João Pinheiro, além da própria Prefeitura Municipal, indicam que o período maior de imigração ocorreu a partir dos anos de 1980. Mineiros, paulistas e fluminenses compõem os grupos que mais aportaram em Tiradentes que, com seu requinte e "ares" de cultura [sic], atraiu intelectuais, artistas plásticos, etc., mudando não somente o perfil demográfico da cidade, mas também suas características sócioculturais.

Junto com o ETs (e, muitas vezes, por influência deles) Tiradentes recebeu as instituições: Fundação Rodrigo Melo Franco de Andrade - FRMFA (1970), Instituto Histórico Geográfico de Tiradentes - IHG (1977) e Sociedade Amigos de Tiradentes - SAT (1980). Houve também um grande apoio de instituições externas como o BID (Projeto Monumenta) e a Fundação Roberto Marinho. Esses novos atores foram responsáveis por mudanças substanciais na paisagem e no cotidiano da cidade.

A Sociedade Amigos de Tiradentes (SAT) foi criada por um grupo de pessoas interessadas na proteção do patrimônio tiradentino e no desenvolvimento local - entre eles podemos citar Yves Alves e José Luiz Alquéres. Araújo (2004:17) aponta a SAT como 
"grande parceiro na revitalização da cidade" e cita John e Anna Parsons (ETs) como grandes

incentivadores. A SAT conseguiu a restauração do órgão da matriz através da Lei de incentivo

à Cultura e o repasse de verbas do BNDS para a restauração do chafariz e da ponte de pedra ${ }^{33}$.

A SAT é uma entidade sem fins lucrativos que muito atuou na recuperação de prédios e que formou o núcleo de pessoas, misto de nativos, moradores e não residentes na cidade, responsável por levar à frente número significativo de iniciativas. Atuou, em trabalho conjunto com o IPHAN, na restauração de prédios, inclusive casas não tombadas, ajudou a criar a corporação de artesãos, organizando e encaminhando-os a feiras em vários estados do país, e elaborou vários textos sobre a cidade e seus elementos culturais e artísticos, publicados em jornais de Belo Horizonte. Dentre sua produção literária destacase um jornal de circulação pela cidade, o "In Confidências". (GIOVANINNI JR, 2002:28)

Segundo o entrevistado Olinto dos Santos Filho, a SAT continua a existir em Tiradentes, mas hoje em dia é pouco atuante.

O Instituto Histórico e Geográfico de Tiradentes foi fundado com o objetivo de estudar e preservar a história local. O IHG reúne seu grupo de parceiros e colaboradores frequentemente e guarda em sua sede mapas e documentos relevantes para a história da cidade, além de atuar com palestras de educação patrimonial nas escolas municipais e manter um blog com posts sobre a história de Tiradentes e temas de interesse cívico para a cidade. Está prevista restauração das igrejas de São João Evangelista e São José com o apoio dessa instituição $^{33}$.

A Fundação Rodrigo Melo Franco de Andrade foi criada, a pedido do então governador Israel Pinheiro, por Maria do Carmo Nabuco

e alguns solidários e generosos amigos que logo acolheram seu chamado Antônio de Carvalho Lage Filho, José de Magalhães Pinto, Theophilo de Azeredo Santos. Ruy Gomes de Almeida, Zaíra de Almeida e Silva - e também importantes apoios do Banco Nacional de Minas Gerais e de José Luiz de Magalhães Lins. A estes vieram somar-se, mais tarde um pouco, as relevantes contribuições, entre outras, do presidente Tancredo Neves, da Fundação Bradesco, da Fundação Roberto Marinho, da Kraftwerk Union, da CEMIG, do arquiteto Alcides da Rocha Miranda, do paisagista Roberto

\footnotetext{
${ }^{33}$ Informação encontrada no site www.tiradentescultural.com.br
} 
Burle Marx, do empresário Yves Alves, da empresária Ângela Gutierrez, do advogado Breno Neves e, mais recentemente, da UFMG, através da incansável reitora Ana Lúcia Gazzola. (Vivi Nabuco In: FROTA 2005)

A Fundação teve influência na recuperação do Fórum, da Casa de Padre Toledo, da Cadeia, da Matriz de Santo Antônio e de várias fachadas da Rua Direita conseguiu com a CEMIG a implantação da rede subterrânea de energia elétrica e com Burle Marx projetos para seis praças da cidade, incluindo o Largo das Forras (FROTA, 2005:114). Atualmente, em parceria com a UFMG (que participa de sua gestão, sendo o reitor o presidente do Conselho Deliberativo), a Fundação está restaurando o Museu Padre Toledo que pertence à mesma, assim como o Fórum, a Cadeia e a Casa de Cultura ${ }^{34}$.

Essa postura que instituições do terceiro setor assumem de "zeladoras do patrimônio" quase sempre apoiadas (sobretudo financeiramente) por empresas, demonstra claramente que a gestão pública (governamental) do patrimônio que se via em 1938 foi substituída por uma gestão compartilhada, na qual a sociedade civil e a iniciativa privada têm papel fundamental. A gestão coletiva é apontada como a melhor forma de preservação na Carta de Amsterdã (1975), que defende a apropriação do patrimônio como uma riqueza social.

$\mathrm{Na}$ prática, contudo, nem sempre a gestão coletiva engloba todas as classes. Leite (2007:77) chama atenção para a recorrente falta de empoderamento das camadas mais pobres, que se vêm excluídas da preservação de seus patrimônios - "Para essas minorias, parece uma triste sina sair do patronato do Estado para o mercenato do mercado".

Indispensável para a escalada da gestão patrimonial em Tiradentes a esse novo patamar, foi a presença dos ETs, já que dentre a população local talvez não existisse, ao

\footnotetext{
34 A FRMFA é, dentre as instituições que atuam em Tiradentes, a mais "extra-tiradentina", por ter seus fundadores, dirigentes, mantenedores e apoiadores "de fora" de Tiradentes. Ao mesmo tempo é a que conseguiu maiores conquistas por ter em seu meio pessoas de grande influência na sociedade por sua posição na política, status econômico ou conhecimento técnico.
} 
menos naquele momento, as condições culturais e cognitivas necessárias para fomentar essas iniciativas.

Por possuírem um poder aquisitivo e um grau de instrução superior à média da população local, cabe questionar se a cidade não começa a assumir um ar de "cidade para snob", denominação de Oriol Bohigas para as "áreas apropriadas por uma elite de artistas, intelectuais, burgueses e, sobretudo, especuladores que vêem nesses conjuntos urbanos um modo de sublinhar sua distinção." (CANCLINE, 1994:105)

No caso dos ETs, houve desde o início uma distinção cultural clara em relação aos moradores locais. A busca de um lugar tranquilo concomitante à transformação desse lugar tranquilo em um território turístico (intranquilo, diga-se de passagem) demonstra como se ensaia nos ETs o que Featherstone (1995) denomina de paradoxo dos intelectuais e artistas, pois possuem "dependência do mercado e, no entanto, sua repulsa e seu desejo de independência em relação a ele".

A distinção é, sem dúvida, uma preocupação das classes mais abastadas na sociedade pós-moderna e a cultura se tornou uma de seus principais veículos. Segundo Featherstone (1995:40) os bens "são usados para delimitar fronteiras entre os grupos, para criar e demarcar diferenças ou o que existe de comum entre grupos de pessoas", o que Hirsch (1976) denominou "bens posicionais". Entre os bens posicionais, além da casa, do carro, das roupas e outros objetos materiais, estão nosso trabalho, cidade de moradia, estilo de vida, dentre outras escolhas que nos diferem dos demais.

Perguntado sobre a relação ente "os de dentro" e "os de fora" na apropriação do espaço tiradentino, Rogério Almeida explicita de forma interessante o relacionamento subordinado, mas pacífico e frutífero existente entre os "minhocas" e os "ETs" :

Como tudo na vida, tem seu lado bom e seu lado ruim. Vamos deixar claro aqui. Os ETs são os extra-tiradentinos e os minhocas são os da 
terra. Então... geralmente os minhocas são empregados dos ETs, certo? Mas assim como tem muito ET babaca, tem muito ET bacana. Então assim... os ETs vieram, os extra tiradentinos ocuparam as casas do centro histórico. Mas a grande maioria se preocupa com a cidade. $\mathrm{Eu}$ acho que as vezes eles se preocupam até mais que os próprios moradores da cidade. A verdade é essa. (In ZOLINI, 2007:128)

Esses novos atores foram fomentando mudanças significativas em Tiradentes ao criarem novos empreendimentos e valorizar o patrimônio (no sentido de mise en valeur) com restaurações, reformas, requalificações, reabilitações, revitalização e todo tipo de "re-invenção". Uma das principais consequências dessas transformações foi um gradativo aumento da atratividade da cidade e, consequentemente, do número de visitantes.

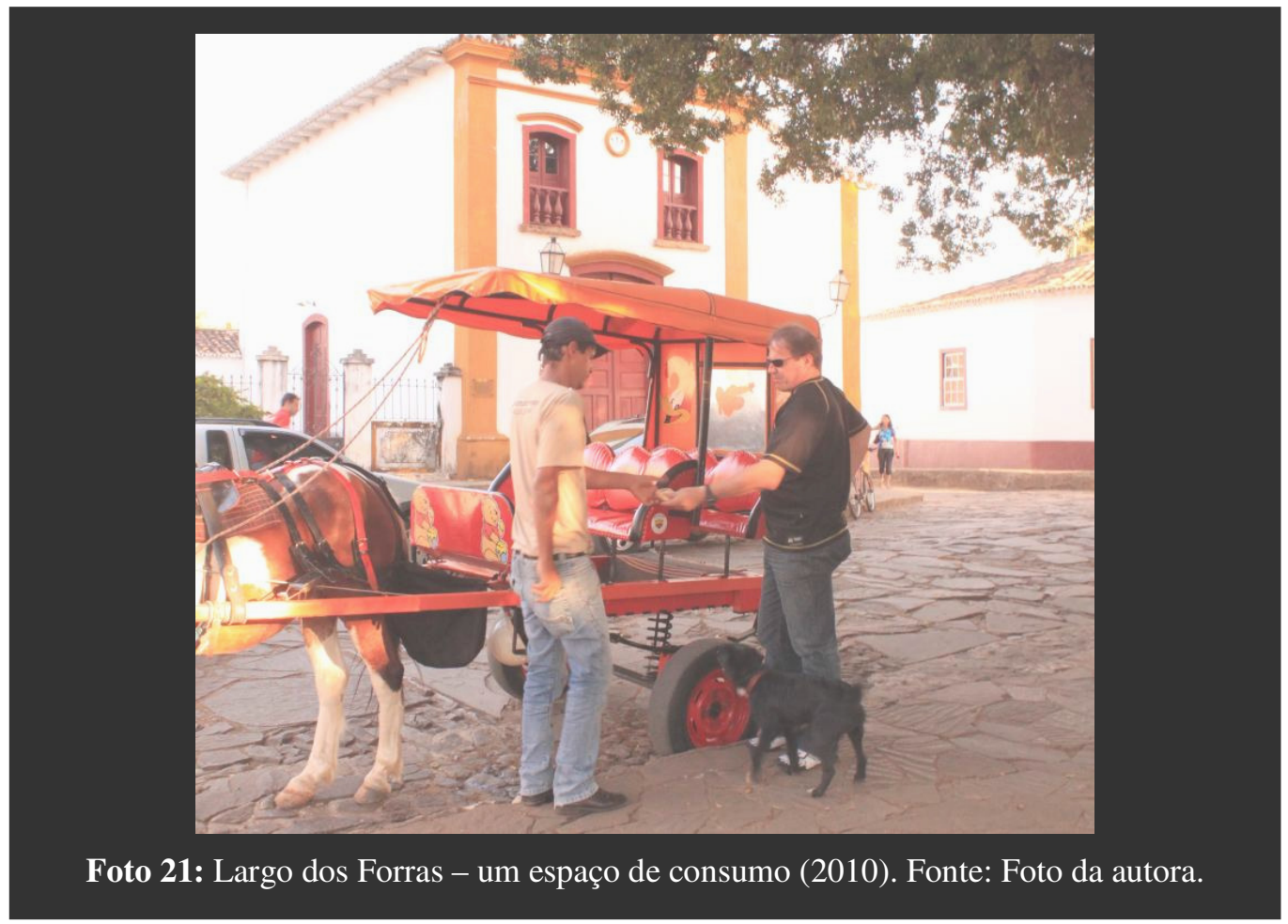

Em Tiradentes o turismo começa a se desenvolver à partir da década de $1970 . \mathrm{Na}$ reportagem "É tempo de acordar Tiradentes" da Revista Horizontes publicada na primavera 
de 1969 fica claro que anteriormente não havia estrutura: "Tiradentes ainda não tem hotel, espera-se a construção de um para breve” (ARAÚJO, 2004:15). Lélia Frota (2005:114) também deixa claro essa realidade quando descreve que na primeira vez que Maria do Carmo Nabuco foi à cidade em 1969 "não havia um único estabelecimento aberto ao público onde se pudesse tomar um copo d'água".

Em 1971 no Largo das Forras é construído o restaurante de Mitula, no local onde havia a casa de Eliseu Resende que ruiu e, onde hoje (com a parte interna totalmente modificada) é o Hotel Mãe D’Água. Em 1974 é construído próximo à ponte de pedra o Bêta da Prata, já como prataria (funcionando até os dias de hoje), mas ainda sem o segundo andar que lhe transformará em sobrado quatro anos mais tarde.

No início da década de 1980 percebe-se que a atividade turística na cidade está um pouco mais estruturada, mas ainda incipiente, como demonstra o Plano de Desenvolvimento para a cidade:

Propiciando infra-estrutura ao turismo, Tiradentes possui três bons restaurantes e quatro hospedagens que variam do padrão ótimo ao regular. A capacidade dos mesmos para atendimento ao turismo se satura nas épocas do ano em que se realizam os principais eventos, mantendo-se, no entanto, ocioso a maior parte do tempo. Seus proprietários conseguem sobreviver nesse período dedicando-se a outros ramos de atividade econômica da cidade (FUNDAÇÃO JOÃO PINHEIRO, 1980:39)

Essas modificações demonstram que além de algumas das formas no Largo das Forras foram alterando-se, sobretudo, as funções. Predominantemente residencial até a década de 1960, passou a abrigar um comércio bastante local (correio, banco, mercado, casa de baile) com exceção das pratarias que vendiam em grande parte para excursionistas. Essa fase, contudo, é aos poucos superada pela substituição do comércio local por empreendimentos mais sofisticados, voltados para um público externo - os turistas. 
Não se pode apontar apenas um motivo para o crescimento do turismo, pois ele foi uma combinação de diversos fatores. D. Ruth Ramalho, antiga moradora da cidade em entrevista a Gisela Souza (2004:13) declarou que passou a vender mais doces aos turistas depois que o presidente Tancredo Neves morreu (1985), pois vários turistas passaram a visitar seu túmulo em São João Del Rey e aproveitavam para conhecer Tiradentes. O asfaltamento dos acessos a São João Del Rey e Barbacena também tiveram grande influência. Nessa década as pratarias também atraiam muitos excursionistas que compravam o artesanato para revender em outras cidades.

Hoje serviços é o principal setor econômico em Tiradentes e no Largo das Forras (figura 08), seguido pela indústria.

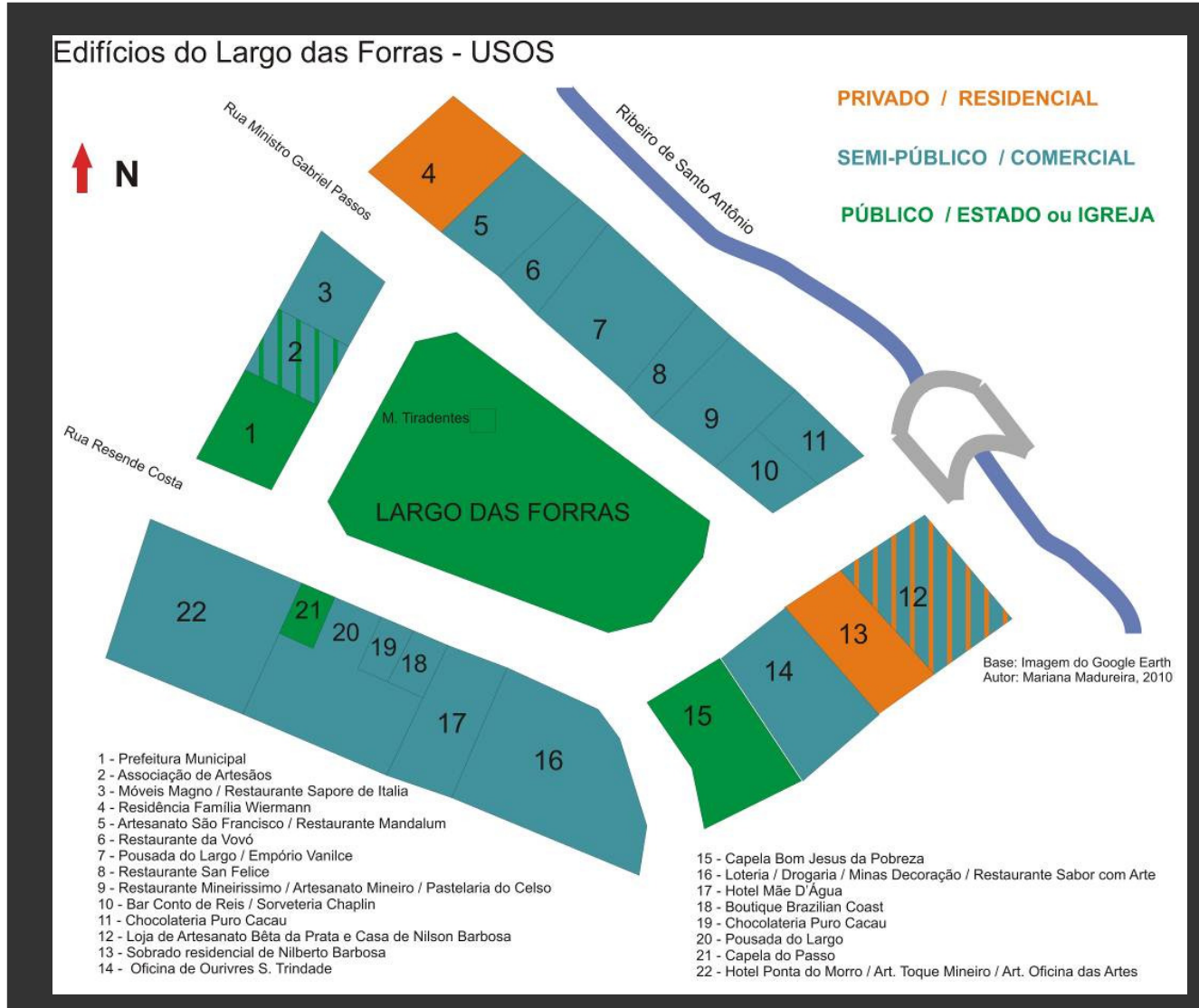

Figura 08: Atuais usos dos edifícios do Largo das Forras. Fonte: Ilustração da autora (2010). 
Segundo a pesquisa de Silveira (2008), mesmo a indústria tem forte vínculo com o turismo, pois se concentra, sobretudo, em móveis rústicos de demolição e artesanato de estanho. Silveira (2008:14) conclui em sua pesquisa que

Os setores de alojamento e alimentação como mostrados na pesquisa, são os que mais empregam e apresentam maiores médias salariais (empresários). De fato, a percepção dos moradores de que o turismo é a principal atividade econômica do município e que a cidade depende economicamente desse setor, parece se confirmar com os números apresentados pelo estudo com base nas fontes e pesquisas aplicadas.

O Largo é hoje um dos principais atrativos turísticos da cidade, e recebe um grande fluxo de turistas, sobretudo nos seus principais eventos ${ }^{35}$. O comércio de interesse turístico é o principal uso dado aos antigos (e nem tão antigos) edifícios do Largo: 3 hotéis, 7 restaurantes, 10 lojas de artesanato e decoração, 2 chocolaterias, uma sorveteria, uma farmácia, uma lotérica, uma boutique e dois bares. Como centro de consumo da cidade capitalista, o Largo não fugiria ao que Lefebvre (1996:120) descreve como duplo caráter:

lugar de consumo e o consumo do lugar. Os comércios se densificam no centro, que atrai os comércios raros, os produtos e gêneros de luxo. Esta centralidade se instala com predileção nos antigos núcleos, nos espaços apropriados no decorrer da história anterior.(...) Nesses lugares privilegiados, o consumidor também vem consumir o espaço; o aglomerado de objetos nas lojas, vitrinas, mostras, torna-se razão e pretexto para a reunião das pessoas; elas olham, vêem, falam, falam-se. E é o lugar de encontro, a partir do aglomerado das coisas. Aquilo que se diz e se escreve é antes de mais nada o mundo da mercadoria, a linguagem das mercadorias, a glória e a extensão do valor de troca.

Luchiari (2000:121) reforça a afirmação de Lefebvre ao concluir que "o turismo é um vetor de transformação contraditório e emblemático: acentua a produção de lugares de consumo e o consumo dos lugares.” No Largo das Forras ele cumpre esse papel.

\footnotetext{
${ }^{35}$ Segundo Oliveira, Pizzolato e Longo (2008) Tiradentes recebe cerca de 50.000 turistas no Carnaval, 40.000 no Festival de Cinema, 30.000 no Festival Gastronômico e 5.000 no encontro de motos. Vale ressaltar que esse número significa do dobro a 10 vezes a população de Tiradentes, que tem aproximadamente 5.000 pessoas.
} 
O turista tiradentino é, segundo pesquisa de Giovaninni Jr. (2002:92), proveniente, sobretudo, do sudeste, de alta escolaridade ( $72 \%$ tem curso superior) e sabem da cidade por meio da mídia (42\%) ou dos amigos (40\%). Segundo uma pesquisa da Prefeitura Municipal aplicada em dezembro de 2008 e janeiro de 2009, a grande maioria dos turistas (76\%) são adultos entre 31 e 60 anos e $64 \%$ são casados. O poder aquisitivo desses turistas é alto, já que apenas $8 \%$ dos entrevistados tinham rendimentos abaixo de 5 salários mínimos, enquanto 64\% declarou rendimento acima de 10 salários. Interessante notar, também, que $64 \%$ dos entrevistados já tinham estado em Tiradentes em outra ocasião, sendo que $20 \%$ já visitaram mais de cinco vezes. Essa freqüência se deve principalmente à origem próxima do visitante (92\% do sudeste), que por sua vez influencia na condução - $84 \%$ usa automóvel próprio.

Podemos concluir, portanto, que o turista que visita Tiradentes vem de perto (sudeste), é adulto, tem um bom poder aquisitivo e alta escolaridade. A propaganda boca a boca é significativa e os turistas tendem a visitar a cidade mais de uma vez.

Percebe-se nas entrevistas de Araújo (2004) que muitas pessoas, sobretudo os moradores mais antigos e idosos, não gostam do turismo por diversos motivos: "tem muita gente estranha na cidade, os turistas" (entrevistado N.105), "o pior é o carnaval, a cidade fica suja" (entrevistado N.45), "aqui só os de fora tem acesso a tudo... só tem valor quem é de fora. Em 35 anos tudo aqui mudou, piorou a vida" (entrevistado N.119), dentre outros depoimentos que se queixam, principalmente do barulho, da violência e da perda da tranquilidade.

Contudo eles são minoria, já que em pesquisa com os moradores sobre as mudanças positivas que ocorreram na cidade nos últimos anos o turismo ficou em primeiro lugar, seguido de vários fatores nos quais influi diretamente: aumento dos empregos, melhoria da infraestrutura, novos eventos e crescimento da cidade. 
Soares (2004) identificou que alguns moradores consideram a cidade cara. Mas ainda assim o artesão entrevistado (Tião Painera), o sacerdote (Pe Ademir Longatti) e o secretário de turismo (Ralph Justino) foram enfaticamente positivos ao destacar a geração de renda e mesmo a "alegria" que a cidade ganhou com o fluxo turístico.

O aumento de empregos e renda pode ser percebido nos números divulgados pela Fundação João Pinheiro: a renda per capita média do município cresceu 97,95\%, passando de $\mathrm{R} \$ 132,01$ (em 1991) para $\mathrm{R} \$ 261,31$ (em 2000). A pobreza (medida pela proporção de pessoas com renda domiciliar per capita inferior à metade do salário mínimo vigente) diminui 55,33\% passando de 52,9\% (em 1991) para 23,6\% (em 2000). O aumento da renda fez com que Tiradentes saltasse do $266^{\circ}$ do lugar para a $146^{\circ}$ no ranking de IDHs entre os municípios mineiros (TADINI JR, 2006:11). Há de se considerar nesses números, além da nítida influência do turismo apontada pelo autor, a influência dos ETs, que ao migrarem para a cidade fizeram subir a média da renda per capita.

O desenvolvimento econômico da cidade pode ser apreendido, ainda, nos exemplos dados por Tadini Júnior (2007): rede wireless gratuita instalada em todo o centro histórico, laboratório de informática, telecentro comunitário, projeto de instalação de câmeras em todo centro histórico, campanha para pintura de residências nos bairros mais pobres da cidade, fiação elétrica subterrânea, entre outros.

Dentre os recursos gerados pelo turismo, grande parte foi dirigida ao patrimônio. A pesquisa de Tadini Jr (2006) no IPHAN local mostrou que de trinta imóveis antigos em estado precário na década de 1980, apenas três ainda não receberam intervenção.

Que houve benefícios econômicos à população e ao patrimônio fica claro. Contudo, um dos maiores problemas do turismo - não só em Tiradentes, mas na maioria dos destinos é a privatização dos benefícios (quase todos financeiros e concentrados nas mãos de poucos) e a socialização das externalidades, que são os custos sociais (aumento da violência, espoliação 
urbana), ambientais (poluição e depredação) ${ }^{36}$ e culturais (espetacularização das tradições, perda da identidade).

Em Tiradentes essa privatização dos benefícios inclui as entradas de divisas que não chegam até a Prefeitura. Segundo Lima (2008:268)

$\mathrm{Na}$ atual conjuntura percebe-se que o turismo ainda não colabora para o desenvolvimento sócio econômico do município e, em alguns casos, faz a prefeitura desembolsar recurso expressivo para o seu funcionamento: no apoio com a logística, funcionamento do trânsito, alimentação das pessoas envolvidas na produção de eventos, segurança pública, reforço policial, dentre outros.

A falta de planejamento (a cidade ainda não tem Fundo Municipal de Turismo) e a sonegação de impostos de donos de empreendimentos turísticos que emitem pouquíssimas notas agravam esse quadro.

Souza (2004) encontrou críticas em relação ao turismo da cidade, como a da gerente de um dos hotéis do Largo.

Para Moema, turismóloga que trabalha na pousada Mãe d’Água, o turismo em Tiradentes cresceu muito rápido e sem planejamento, segundo ela se for colocado em uma balança, de um lado os impactos positivos, e de outro os impactos negativos, todos sairão perdendo, tanto os ambientes culturais, sociais e até mesmo o alcance do equilíbrio do turismo; Moema considera que urge planejar os espaços para receber o crescente fluxo de turistas em Tiradentes (SOARES, ibidem).

Vale ressaltar que uma grande (e muito pertinente) preocupação da entrevistada citada é a dependência que a cidade de Tiradentes criou em relação à atividade turística. Sabe-se que o turismo é um bem de consumo altamente elástico e sazonal sendo, portanto, frágil. Gustavo Pinto (2008) conclui em seu artigo sobre o desenvolvimento turístico na cidade que:

Infelizmente, a tendência do turismo no local não é das melhores. Um grande número destes empreendimentos [turísticos] vê hoje dificuldades em enfrentar tanto o grande número de concorrentes, quanto à sazonalidade.

\footnotetext{
${ }^{36}$ Os impactos ambientais não estão no escopo desta e pesquisa e não foram abordados nesta dissertação. Para saber mais a respeito consulte LeSann (2007).
} 
Assim, Tiradentes, que na década de 1980 possuía 60 leitos em seus então 4 meios de hospedagem, e hoje possui mais de 60 meios de hospedagem, vê parte deste equipamento não resistindo ao boom sem planejamento urbano turístico.

A descrição de Giovaninni (2002:37) é eficiente para compreensão de como o turismo, apesar de ter melhorado alguns aspectos, não resolveu os principais problemas de Tiradentes:

Em meio a essa cultura globalizada, presente na culinária, na arte, nas relações interpessoais, na presença de instituições, a cidade não modernizou sua infra-estrutura urbana, nem suas relações políticas. Não dispõe de uma legislação eficiente, não tem plano diretor, nem leis definidas de uso do solo, nem código de postura. Mesmo a arrecadação municipal não é eficiente e a maioria do comércio não paga os impostos corretamente à prefeitura, fazendo com que a indústria do turismo gere renda apenas para os proprietários. As eleições ainda seguem o modelo coronelista de voto de cabresto e se divide entre famílias rivais tradicionais.

É preciso atentar, também, para o fato de que o louvor ao turismo por parte do Estado (e, consequentemente as propagandas que vem dele) é, freqüentemente, uma tentativa de legitimação das políticas e posturas adotadas pelo governo ou uma estratégia de marketing para a contínua atração de empreendimentos e consumidores - e não um retratação fiel dos benefícios da atividade para o município.

Os mecanismos do mercado aparecem triunfantes, trazendo o novo e conservando o velho, em função dos ditames da produção, impondo o externo ao interno nos setores em que isso lhes convém e arrastando o Estado para a órbita dos interesses privados. A internalização do externo, a renovação do antigo a serviço das forças do mercado não seria possível sem o apoio, ainda que não deliberado, do Estado. (SANTOS, 1997:80)

Vainer (2000:78) acredita que atualmente "a cidade é uma mercadoria a ser vendida, num mercado extremamente competitivo em que outras cidades também estão à venda". O que elas vendem, segundo o autor, depende das "características dos compradores visados", pois "idosos podem querer calma e grande número de serviços médicos, religiosos podem preferir grande concentração de lugares de retiro e prece, jovens podem estar buscando certos tipos de entretenimento e lazer, etc". 
No caso de Tiradentes os tipos de eventos e serviços ofertados deixam claro que não há uma delimitação forte quanto à idade, sexo, etnia ou credo dos seus visitantes, havendo, contudo, uma clara inclinação de todas as ações para atração de um público de classe econômica privilegiada.

O realismo da proposta fica claro quando nossos pragmáticos consultores deixam claro que esta abertura para o exterior é claramente seletiva: não queremos visitantes e usuários em geral, e muito menos imigrantes pobres, expulso dos campos ou de outros países igualmente pobres; queremos visitantes e usuários solventes. (VAINER, op cit)

A introdução do projeto de sinalização de Tiradentes elaborado por Albano e Freire (1997:02) deixa clara a inserção do município nesse "mercado":

A disputa pelo mercado turístico é cada vez maior e a competição entre as cidades tende a crescer. Tiradentes, em particular, reúne condições bastante favoráveis para melhorar sua performance na indústria da hospitalidade, tornando-se a primeira cidade em Minas Gerais a implementar um projeto de sinalização interpretativa.

Tadini Júnior (2006:06) acredita que em destinos turísticos é recorrente a prática de se esconder "a realidade da cidade, camuflando seus problemas sociais, culturais, ambientais e econômicos, como se fossem "cidades-modelo"”.

Do ponto de vista da turistificação, esse fenômeno se explica pela divisão da cidade em partes turísticas e não turísticas, entre cenários (criados para atrair visitantes) e bastidores (onde a população se recolhe). Em Tiradentes o centro histórico cumpre seu papel de cenário, enquanto os novos bairros abrigam as pessoas e usos que já não cabem mais nele.

Enquanto na cidade cenário ocorre o consumo do lugar pelos visitantes, "o entorno, indigno de ser visto, é intencionalmente escondido" (YÁZIGI, 2003:259) “Os cenários impecáveis, ascéticos exibem a paródia da história, devidamente explicados, exibidos, palatáveis para o consumo" (HENNIG, 2007:95). Essa cidade cenário, ou stage setting como 
denominou MacCanell (1976), é hoje conhecida como "cidade empreendimento", "cidade vitrine", "cidade competitiva" e, mais comumente, "cidade espetáculo". Enquanto espetáculo, pode-se dizer que se trata do "capital em tal grau de acumulação que se torna imagem" (DEBORD, 1997:25). Tiradentes hoje é imagem.

Segundo Costa (2008:07), Tiradentes entra nessa fase em 1990.

Da década de 90 aos dias de hoje, num quarto e último momento, que denominamos fase de cenarização progressiva do patrimônio, os núcleos urbanos detentores de reconhecido acervo cultural vêm passando por um processo de (re)produção mais intenso, que ocasiona a transmutação dos valores a eles inicialmente atribuídos - símbolos de identidade e cultura na construção do "Brasil-nação"-, dadas as novas relações mediadas pela dinamização dos meios de circulação e pela fluidez da informação, nas quais novos objetos e novas técnicas entremeiam esses bens para atender uma nova demanda externa, intensificando o processo de "banalização pela cenarização.

Segundo Françoise Choay (2001:211) vai se criando uma “engenharia cultural”, cuja "tarefa consiste em explorar os monumentos por todos os meios a fim de multiplicar indefinidamente o número de visitantes".

Para atrair cada vez mais visitantes o território turístico vai sendo constantemente alterado e muitas vezes, segundo Luchiari (2000), torna-se a reprodução daquilo que se valoriza no local de origem dos turistas. Problema para o qual Harvey (2001:271) alerta ao afirmar que "lugares retratados de certa maneira, em particular se têm a capacidade de atrair turistas, podem começar a 'se vestir' segundo as prescrições das imagens-fantasia”.

Boaventura de Souza Santos (2002) acredita que as sociedades se vêm através das imagens de si mesmas, como se fossem espelhos. Os espelhos são importantes para a sociedade como meio de identificação de si próprias, no entanto, o uso abusivo dos mesmos faria com que eles adquirissem vida própria e se tornassem independentes de suas imagens. 
Mais do isso, a sociedade corre o risco de deixar de se enxergar no espelho para refleti-lo.

Nesses casos o espelho

De objecto de olhar, passa a ser, ele próprio, olhar. Um olhar imperial e imperscrutável [...] é como se o espelho passasse de objecto trivial a enigmático [...], de espelho passasse a estátua. Perante a estátua a sociedade pode, quando muito, imaginar-se como foi ou, pelo contrário, como nunca foi.

\subsection{A CRIAÇÃO DOS FESTIVAIS E A IMAGEM DA CIDADE}

"O espetáculo não é um conjunto de imagens, mas uma relação social entre pessoas mediadas pela imagem". (Debord, 1997:13)

A imagem, assim como os valores dos bens culturais, deve resultar da relação do homem com o homem e não de uma relação direta do homem com o objeto ou o objeto isolado. Segundo Ulpiano Meneses (2000:37) “deslocar tais atributos das relações para as coisas é o que se chama reificação, fetichização, e que é fonte de alienação permanente". Com base nisso podemos concluir que a imagem de Tiradentes não existe em si, mas no imaginário das pessoas.

A imagem é fundamental na sociedade do espetáculo quando o ser, e mesmo o ter, foram suplantados pelo parecer (DEBORD, 1997). Nesse sentido a veracidade histórica (ou autenticidade material) do casario de Tiradentes não é importante. O importante é que ele pareça colonial. Viemos afirmando ao longo desse trabalho que Tiradentes é imagem, pois a cidade se preocupa cada vez menos com sua essência para se preocupar, predominantemente, com a sua aparência. Tiradentes parece tranquila, parece colonial, seus eventos parecem tradicionais e seu povo parece receptivo e feliz. 
Indissociável da imagem está o imaginário, que, segundo Ferrara (2003:46) "corresponde à pratica social de atribuir significados a significados, ou seja, prática social pela qual os significados passam a acumular imagens e significar mais". Segundo a autora "o imaginário é uma característica da organização social: sua identidade ou sua máscara, verdade ou mentira, real ou manipulado, o imaginário nos diz menos sobre si próprio que sobre a sociedade que o constrói”.

O imaginário de Tiradentes nos diz muito sobre sua sociedade, dividida entre os "minhocas" e os "ETs", convivendo com os fluxos instáveis de turistas, entre o passado e o presente, entre o sagrado e o profano, entre o real e o imaginário... e na constante busca de sustentar a imagem que se espera da cidade.

O turismo busca, muitas vezes, espetacularizar manifestações tradicionais com vistas a valorizá-las frente ao público externo. Existem vários tipos de manifestação. Poderíamos dividi-las, do ponto de vista da motivação, em três tipos distintos: de tradição, de permanência e de difusão.

Uma manifestação de tradição existe por uma motivação específica que pode ser homenagear um santo, comemorar uma colheita, recordar um episódio da vida de Cristo, entre outros. São carregadas de simbolismos e cada detalhe possui um significado para seus praticantes.

Uma manifestação de permanência, por sua vez, visa manter a tradição não mais em seu sentido original - que já não existe - mas em respeito ao seu passado e às suas raízes. São, muitas vezes, praticados pelas novas gerações em reverência aos pais e avós.

Uma importante conseqüência desses processos que elucidam a articulação reflexiva entre o global e o local é a transformação do costume local em relíquia, como forma de localizar a tradição em contextos marcados pela destradicionalização, (...) por meio da qual os costumes continuam a existir na forma alterada de seus significados como relíquia ou hábito (GIDDEN, 1991). 
Uma manifestação de difusão, por sua vez, é típica dos territórios turísticos, pois visa apresentar uma manifestação a um público externo. Como colocou o professor José Carvalho $(2004: 71)$

No caso mais frequente, os rituais tradicionais sofrem uma redução semiológica e semântica no momento em que são transformados em espetáculo comercial. Um cavalo marinho, por exemplo, que dura 12 horas em uma rua de um bairro periférico do Recife, é mutilado para apresentação de uma hora em um circuito público de lazer controlado pela Secretaria de Turismo. Sofre o desgaste parecido com o de uma obra literária publicada pela Seleções do Reader's Digest, que reduz as 1.800 páginas de Guerra e $P a z$ a 200 páginas de uma leitura leve.

É comum essas manifestações passarem por alterações para se tornarem mais “interessantes" e mesmo lucrativas. Surgem novas roupagens, música e coreografia. Literalmente a espetacularização da tradição. Muitas vezes características tradicionais são modificadas por razões estéticas, pois os "produtores culturais" ou os "construtores de imagens" buscam símbolos identitários que consideram mais adequados, como no caso dos uniformes dos soldados indianos:

$\mathrm{Na}$ década de 1860, os britânicos empreenderam um levantamento arqueológico para identificar os monumentos importantes da Índia e preservar a "herança" indiana. Acreditando que as artes e ofícios locais estavam em declínio, recolheram artefatos para pôr em museus. Antes de 1860, por exemplo, tanto os soldados indianos quanto os britânicos usavam fardas de estilo ocidental. Aos olhos dos britânicos, porém, os indianos deviam parecer indianos. Os uniformes foram modificados para incluir turbantes, faixas e túnicas, vistos como "autênticos". (GIDDENS, 2000)

Faz parte do grupo do que Hobsbawn e Terrance (1984:13) denominaram de tradições inventadas. Segundo os autores é natural que haja adaptações nas tradições quando é necessário "conservar velhos costumes em condições novas ou usar velhos modelos para novos fins" o que é diferente da invenção, cuja "inovação não se torna menos nova por ser capaz de revestir-se facilmente de um caráter de antiguidade". 
Nem sempre, contudo, a invenção parte de grupos exógenos. Mais comum, todavia, é que esses grupos busquem resgatar, ou recuperar tradições que já não pertencem à sua geração. Hobsbawn (2000:133) levanta esse questionamento na obra $O$ novo século: "Por que, em um mundo que fala inglês, os galeses, que têm a sorte de falar inglês desde a infância, querem redescobrir o galês? Por que em Londres as jovens islâmicas querem se vestir como suas avós quando vão à mesquita?”.

A explicação talvez esteja em uma reação à globalização. Quanto mais o mundo se unifica e se homogeniza, maior se torna a necessidade de afirmar-se diferente e de, algum modo, resgatar hábitos que estão se perdendo ou já se perderam. Mais do que uma forma romântica de preservação cultural, é uma forma de sobrevivência no mundo do capital. Afinal, como se pode trocar quando tudo é igual?

Em Tiradentes ainda há manifestações tradicionais, principalmente porque a religiosidade ainda é forte entre os tiradentinos e a maior parte das manifestações tem esse caráter.

Ir ver a face de Deus, vestir a roupa de ver Deus são práticas freqüentes na vida dos tiradentinos. No cotidiano a fé transparece na linguagem, no nome das plantas como ora-pro-nobis, na ida a rezadeiras católicas, nas bonitas cruzes de papel crepom colocadas nas portas das casas como proteção, na frequiência às confrarias e "conferências" ${ }^{, 37}$ que atuam durante todo o ano, perpassando vários níveis de classes sociais. (FROTA, 2005:147)

\footnotetext{
37 “A conferência, explica-nos o maestro Joaquim Ramalho, é leiga, "vê as pessoas necessitadas, a gente dá um amparo, ultimamente muito para a casa de moradia. Às vezes, talvez, uma conferência só não dá, a gente indica outras e a pessoa percorre as conferências, uma dá três sacos de cimento, outra dois. (...) Além disso, um confrade dá uma cesta com mantimentos. Já a confraria cuida mais da administração do culto e da igreja'. (...) 'Antes do patrimônio', declara o ex-prefeito Francisco Barbosa, 'as confrarias já cuidavam das igrejas'." (FROTA, 2005:147)
} 




Foto 22: Semana Santa em Tiradentes de Tarsila do Amaral (1924). Fonte: Frota(2005:51).

No centro da praça [Largo das Forras], em um grande canteiro circular, à sombra de uma árvore de porte altivo, uma manjedoura com o menino. Ao seu lado a mãe, o pai, e mais afastados, alguns animais. Não estão em fuga nem se escondendo em uma estrebaria distante. Estão expostos em praça pública, na área central da pequena cidade já faz 25 dias. Todos os anos estão ali, aos olhos de homens, crianças, mulheres, idosos, turistas, moradores e nativos, comerciantes padres e beatas. São admirados e apreciados, às vezes louvados por um coral de crianças de alguma escola ou por músicos que passam pela cidade, enriquecendo o cenário e consagrando o momento como espetáculo. (GIOVANINNI JR, 2002:09)

Contudo, algumas dessas manifestações sofreram adaptações. Um exemplo das

transformações que os eventos tradicionais vieram absorvendo desde o aporte dos ETs e do turismo na cidade é a Folia de Reis. Segundo o representante municipal do IPHAN Olinto dos

Santos

Quem sofreu mais com as alterações sociais e econômicas foram as manifestações da cultura popular que mudam de área geográfica, como a Folia de Reis. Porque a folia de reis ela vai de casa em casa das pessoas conhecidas né? Então hoje uma folia não circula mais no centro histórico, porque não tem população local para receber, isso muda completamente. Então elas deslocaram mais para a área rural e para as periferias. (...)Então é... em relação também à Folia de Reis é... é uma coisa também um pouco drástica, quando se apresenta hoje... tem as vezes umas apresentações na 
véspera do Natal ou depois do Natal, no presépio da praça. Mas aí são... não tem mais o caráter espontâneo, é uma apresentação mais programada, para turista, que não tem mais o mesmo sentido. (In: ZOLINE, 2007:157)

Da mesma forma Camurça (2003:41) afirma que “uma procissão, a de São Francisco, deixou de circular pelo centro, pois estava já quase totalmente ocupado por pessoas de fora e aqueles que organizavam esta festa já estavam no bairro Cascalho. Assim mudaram seu trajeto e hoje ela só se realiza no bairro".

A Igreja e os fieis ainda se esforçam para manter o significado de seus eventos e ritos, mas a convivência com "os de fora" e com o profano nem sempre é fácil. O pároco local entrevistado por Camurça e Giovaninni (2003:229) declarou que

Ultimamente tenho feito uma campanha aqui em Tiradentes com as pessoas que participam da igreja, das missas, pra ter um cuidado muito grande para não esvaziar o sagrado. Devido ao mundo materialista de hoje que só pensa em dinheiro. Aqui em Tiradentes só se pensa em atrair turista e que a cidade fica cheia de turista o dia todo (...). Olha este lugar aqui é sagrado, a igreja foi feita há quase trezentos anos atrás, não é pra fazer concerto, isso é teatro que faz.

O pároco afirmou aos pesquisadores que não radicaliza a ponto de impedir qualquer tipo de evento profano na igreja, mas escolhe com critério, pois segundo o religioso “já chegou uma época que nós permitimos fazer concerto e teve gente que fumou lá dentro da igreja, turista, pessoa que vê a igreja como uma casa qualquer". Um demonstrativo de que o turismo influi negativamente sobre a vida religiosa da cidade foi o abandono da Irmandade de Santo Antônio por um grupo que não aceitou a criação da taxa de visistação para a Matriz. Eles contestaram: "Uai padre, mas não pode cobrar pra entrar na Matriz, lá é casa de Deus...”. (GIOVANINNI, 2002:72)

As confrarias e os eventos religiosos tendem a resistir, mas precisam se deslocar ou se flexibilizar para conviver com as modificações que ocorreram nos últimos anos. O público religioso de Tiradentes acabou por se organizar no que Magnani $(1999,2002)$ chama de 
circuito. Diferente do "lugar", da "mancha" ou do "pedaço", o circuito não depende de um espaço físico, mas se constrói em torno de um interesse comum - como os cinéfilos (frequentam os mesmos cinemas, locadoras, etc), os intelectuais (cafés, bibliotecas, universidades), entre outros. Em Tiradentes o grupo frequenta o centro nas procissões, a igreja nas missas, os passos na Semana Santa, as confrarias nas reuniões e o Largo nas festas religiosas.

Outras formas de resistência cultural ainda existem na cidade, segundo Lélia Frota (2005:111). A autora conta que "Jango Goulart da Silva, entalhador, é hoje também o fogueteiro das festas da cidade, em substituição ao antigo Antonio Ferreira Gomes. Outro filho [irmão de Jango] toca primeiro e segundo violino na Orquestra Ramalho, e a mãe, Madalena, canta no coral".

Outra forma de expressão artístico-cultural importante em Tiradentes são os trabalhos artesanais. O artesanato tiradentino ganhou sua primeira visibilidade na década de 1960 , quando surgiram as pratarias que foram, inclusive, o principal motivo da visita de excursionistas à cidade nessa década. Essa relação demonstra que desde o início o artesanato e o turismo estiveram intimamente conectados.

O turismo cultural fez com que se retomassem ou se desenvolvessem aptidões já existentes entre os moradores. Ampliou-se o exercício dos artesanatos de prata, da olaria, logo seguidos de uma expansão dos de talha, marcenaria, bordado, pintura, doçaria, funilaria, das pedras da região - onde se destacam as delicadas cópias do Relógio do Sol existente na Matriz. (FROTA, 2005:150)

O que Frota chama de "desenvolvimento de novas aptidões" introduz, contudo, um grande risco da associação entre turismo e artesanato: a fetichização dessa arte popular com a transformação da manufatura em souvenir. Há nos territórios turísticos, de modo geral, uma tendência à substituição gradativa do trabalho tradicional e doméstico pelo souvenir industrial “estilo artesanato". 
Cancline (1997:211) acredita que exista, na atualidade, uma "fascinação pelos produtos, um descaso pelos processos e agentes sociais que os geram, pelos usos que os modificam" o que "leva a valorizar nos objetos mais a sua repetição que sua transformação".

A própria Lélia Frota (2005:151) aponta as mudanças como significativas:

Como vem acontecendo em linhas gerais em todo o país, dá-se também em Tiradentes uma transformação na produção artesanal. Muitas vezes naquilo que antes era utilitário, predomina agora a categoria do estético, uma vez que o público comprador das classes médias e altas vê com outra ótica o artesanato regional.

A autora acredita, contudo, que essas mudanças não implicam "necessariamente uma queda na qualidade dos produtos”, podendo representar até mesmo uma evolução das técnicas tradicionais, em alguns casos.

Assim como o turismo mudou as técnicas artesanais (tornando-as ao mesmo tempo mais "evoluídas" e menos tradicionais), ele criou novos eventos para a cidade.

Ao longo do ano muitos eventos de massa são organizados na cidade, como a "Mostra de Cinema" em janeiro, o Carnaval, o "Encontro de Motoqueiros" em junho, o "Festival de Gastronomia" em agosto, sem falar dos eventos menores, mais elitizados, e os eventos tradicionais religiosos. Tudo isso, então, vem acompanhado, é claro, de um intenso fluxo de pessoas, algumas vezes maior que o suportado pela cidade. (GIOVANINNI, 2002:30)

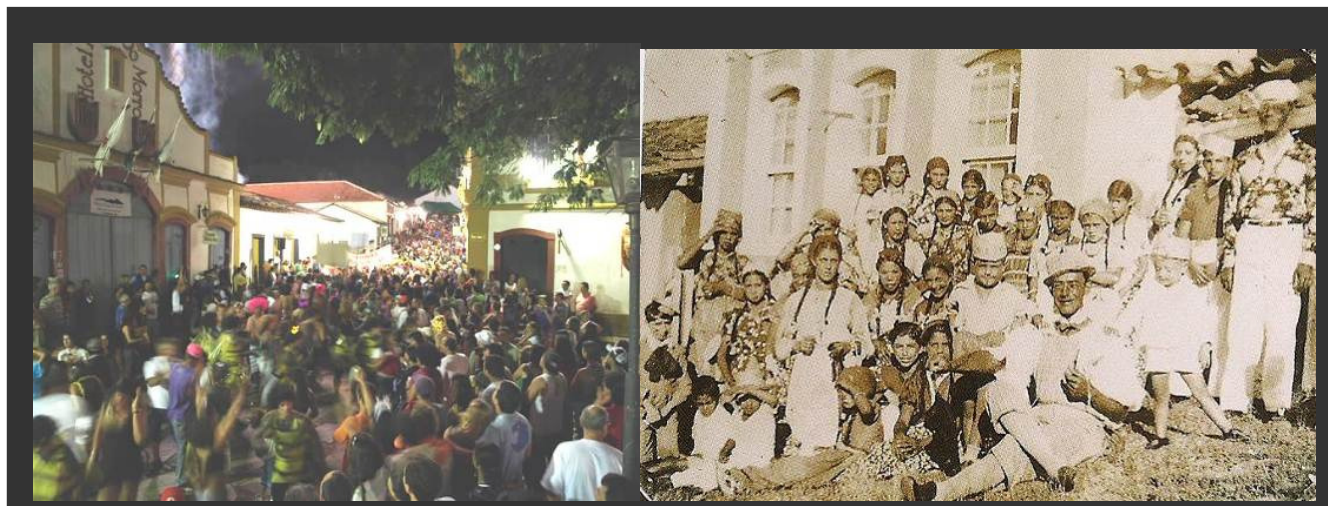

Foto 23: Carnaval no Largo das Forras [2000]. Fonte: Prefeitura Municipal.

Foto 24: Carnaval em Tiradentes (1950). Fonte: Frota (2005:152). 
Um aspecto importante para o aumento da demanda do turismo na década de 1990 foi, segundo Tadini Jr., a invenção dos festivais e eventos sofisticados

O poder público local procurou consolidar os eventos tradicionais, como a Semana Santa, a comemoração da Inconfidência Mineira e o Carnaval (retomando as antigas "marchinhas" de carnaval), além de organizar eventos que abrangessem demandas e públicos específicos. No primeiro semestre de 1998, foi criada pela Secretaria de Turismo da cidade, a primeira Mostra de Cinema de Tiradentes e no segundo semestre do mesmo ano o festival gastronômico (Fest Gourmet). A proposta foi criar atrações diferenciadas que permitissem à cidade suplantar as estratégias desenvolvidas por São João Del Rei, redirecionando o fluxo e o interesse do público-alvo visado. Dessa forma, o planejamento turístico concebido, envolveu a construção de estratégias que incorporassem um conceito de hospitalidade e promoção de atividades culturais com temáticas voltadas um segmento mais sofisticado, de renda mais elevada e ávida por novos conhecimentos e relacionamentos (cinema, gastronomia, história, entretenimento). (TADINI JR, 2006:09. Grifo nosso).

Os novos eventos possuem uma dinâmica própria e independente dos eventos tradicionais que ainda sobrevivem em Tiradentes e atraem, predominantemente, o público local. A Semana Santa é o maior exemplo destes. As principais diferenças entre esses eventos (frequentados pelos "de dentro") e os festivais de cinema e gastronomia (freqüentados pelos "de fora") são a tradição (ou a falta dela) e a motivação. Enquanto os primeiros existem há séculos e foram criados por motivações, sobretudo, de fé, os mais recentes são sofisticados e não guardam relação com a história e a identidade da cidade, já que antes de sua invenção na década de 1990 não havia absolutamente nenhum vínculo da cidade com o cinema ou com a alta gastronomia. Diferente dos três tipos de manifestação citados no início deste capítulo (tradicional, de permanência e de difusão), esses dois festivais não possuem relação com nenhuma manifestação e sua motivação é unicamente o incremento da demanda turística.

\section{Desvinculados da tradição e da identidade tiradentina, os festivais são eventos} comerciais inventados.

Harvey (1989:308) acredita que esse processo de criação de novos eventos está intimamente relacionado às características do capitalismo, "expansionista e imperalista". Elas 
fazem como que "a vida cultural, num número cada vez maior de áreas, vai ficando ao alcance do nexo do dinheiro e da lógica da circulação do capital."

Esses eventos comerciais possuem, contudo, uma faceta cultural diretamente associada ao que Featherstone (1995:110) considera típico da experiência cultural pós-moderna

Mescla desorientada de signos e imagens, ecletismo estilístico, jogos com signos, mistura de códigos, ausência de profundidade, pastiche, simulação, hiper-realidade, imediatez, um mélange de ficção e de valores estranhos, experiências carregadas de intenso afeto, a queda das fronteiras entre a arte $\mathrm{e}$ a vida cotidiana, uma ênfase nas imagens em detrimento das palavras, a imersão lúdica em processos inconscientes em oposição a uma valorização distanciada e consciente, a perda do sentido da realidade da história e da tradição, a descentralização do sujeito.

Nesse sentido podemos citar sincretismos inusitados como a inserção do quiabo na alta gastronomia ou da música caipira no repertório dos festivais de alta cultura. Essas mesclas podem ser compreendidas como desencaixes e reencaixes (GIDDENS, 2002) e sua principal função seria territorializar os eventos externos, uma estratégia que busca ao mesmo tempo legitimar a conexão entre o evento e sua sede e atrair mais turistas dentro da perspectiva da economia da experiência.

A economia da experiência é, em si, um exemplo de invenção pós-moderna. Para garantir a distinção não basta mais fazer turismo como as massas, de dentro de um ônibus jardineira fotografando e aproveitando passivamente seu tour. O turismo pós-moderno oferece interação (podemos citar como exemplo a participação do turista na preparação dos pratos nas oficinas do Festival Gastronômico) assim como a TV digital, os parques temáticos, a internet 2.0 e os museus de última geração.

Esses produtos culturais são capazes de atrair um público de alto poder aquisitivo, disposto a pagar pelo produto-experiência e pelo consumo da imagem do evento - que lhe proporciona status.

Em uma sociedade de consumo na qual o mesmo de "mero reflexo da produção" passa a desempenhar papel "fundamental para a reprodução social". A cultura do consumo é um 
termo que informa que nos nossos tempos "o consumo deixa de ser simples apropriação de um valor de uso para tornar-se consumo de signos e imagens, em que a ênfase na capacidade de remodelar incessantemente o aspecto simbólico ou cultural da mercadoria torna mais apropriado referir-se a signos-mercadorias" (FEATHERSTONE, 1995:109). Os Festivais de Cinema e Gastronomia se tornaram os grandes signos-mercadorias de Tiradentes.

No Plano de Desenvolvimento de 1980 é citado como maior evento a Festa da Santíssima Trindade que, segundo o diagnóstico (1980:41), “chega a reunir mais de 3 mil romeiros”. Em contraste com esse número, o Festival de Cultura e Gastronomia de Tiradentes em sua $13^{\text {a }}$ edição em 2010 atraiu aproximadamente 30 mil pessoas ${ }^{38}$. Tadini $\mathrm{Jr}$ (2006:10) mostra como o Festival de Cinema já era significativo 5 anos antes:

Apenas na Mostra de Cinema de 2005, um dos eventos de maior destaque da cidade de Tiradentes, foram gerados, para a economia local, cerca de $\mathrm{R} \$ 2$ milhões e mais de mil empregos diretos e indiretos. Durante o evento, todos os 4.700 leitos das 105 pousadas da cidade foram ocupados. O orçamento do evento foi de $\mathrm{R} \$ 940$ mil, captados por meio das leis Federal e Estadual de Incentivo à Cultura.

A população local parece dividida com relação aos benefícios desses eventos. Segundo entrevista realizada por Geisa Soares (2006:08)

Rosângela Rosa, garçonete no Restaurante Boi Uai disse que Tiradentes começou a ter emprego depois da Mostra de Cinema, do Festival de Gastronomia e outros eventos que acontecem na cidade: "provavelmente se não fosse o Turismo, as pessoas daqui teriam que ir para outro lugar para trabalhar".

Um entrevistado de Araújo (N.56, 2004:47), contudo, afirma que “a cidade está ficando muito conhecida por causa dos eventos. É uma doideira”. A descrição de Giovaninni

\footnotetext{
${ }^{38}$ Segundo entrevista dada por Ralph Justino (organizador do Festival) a Marcelo Alves (jornalista e dono do Blog São João Del Rey Alternativa) em 23/08/2010.
} 
Jr (2002:32) do carnaval de Tiradentes em 2001 permite compreender o que o entrevistado quis dizer:

A cidade nesse ano foi assediada por um número extremo de pessoas ${ }^{39}$, maior do que podia comportar. Multidão de jovens tomados por uma animação carnavalesca muito próxima ao que poderia se pensar em termos de Salvador ou Recife, porém entre as pequenas e frágeis paredes de Tiradentes. Sem infra-estrutura para receber esse contingente de foliões, a cidade virou um caos. O resultado foi muita bagunça, destruição, sujeira e violência, fato este que apavorou o pessoal da cidade e também os turistas mais românticos.

Geralmente a parcela da população insatisfeita é aquela (grande) parte que não se beneficia diretamente da renda gerada e não se sente à vontade para participar do evento para lazer (há relatos de que a sofisticação desses eventos inibe a participação popular), restando apenas os distúrbios como o barulho, a violência e a sujeira da cidade.

Um dos entrevistados por Fernanda Lima (2008:261), funcionário da prefeitura, admitiu que há exclusão:

Na Mostra de Cinema não há integração com os moradores. Por que os responsáveis pelo evento não incentivam os moradores a montarem um filme para ser exibido na mostra de cinema? São eventos que não são feitos para a população. Por que o evento de gastronomia não pode envolver os cozinheiros da cidade? Um prato é $\mathrm{R} \$ 115,00$ por um mestre francês. Por que a cidade não comemora mais a Festa de São João, mas eventos que chamam turistas? Acabaram as festas locais como o congado.

Mas Ralph Justino (O TEMPO, 2007:18), organizador do Festival Gastronômico (e

ET), afirma tratar-se de um "espaço democrático". Ele declarou que

"O evento foi pensado, desde o início para ser sofisticado, trazendo a alta gastronomia para mais perto da gente. Os festins, que são os jantares preparados por grandes chefs nacionais e internacionais, são realmente para um público interessado em gastronomia que investe nisso e para turistas, já que, há dez anos, quando pensamos o evento, Tiradentes não tinha tanta visibilidade e estava precisando de movimento", afirma Justino. "Mas a cidade está envolvida como um todo no festival. Existe uma programação gratuita que envolve cursos, degustações, atrações culturais desde nossa primeira edição".

\footnotetext{
${ }^{39}$ Segundo o Corpo de Bombeiros (In: Cerqueira, 2006:308) no ano seguinte (2002) a cidade recebeu em torno de 40 mil visitantes (a população local é de 5 mil) tendo esse número de pessoas extrapolado o limite da rede de esgoto e ter faltado água, estacionamento, sanitários públicos e dentre outro problemas de infraestrutura.
} 
Outro demonstrativo de que os benefícios dos novos eventos para o município é uma questão controversa é o resultado estatístico da pesquisa de Márcia Araújo (2004): 5\% dos entrevistados apontaram o surgimento dos grandes eventos como mudança negativa nos últimos anos, enquanto exatamente outros $5 \%$ apontaram o mesmo como mudança positiva. Negativas ou positivas, é consenso que os eventos trouxeram modificações para a cidade: “A Mostra de Cinema e outros eventos foi o que mais mudou a cidade"(entrevistado N.121 In: ARAÚJO, 2004:133).

O estudo de caso de Campos (2006:74) aponta que o rápido crescimento da demanda turística em Tiradentes "além dos eventos" ocorreu por conta da promoção da cidade na mídia, “sobretudo pela sua utilização como ‘cenário' para produções da TV Globo”. Por influência do diretor Yves Alves (ET) a Fundação Roberto Marinho investiu na recuperação de vários casarios e mostrou a cidade ao mundo através de filmes como o Menino Maluquinho, novelas como Coração de Estudante e as minisséries JK, Hilda Furacão e Memorial de Maria Moura, entre outros.

Um demonstrativo claro da grande influência da mídia na criação da "cidade presépio" é encontrado em um relatório de Isabel Câmara (IPHAN local) sobre a reunião que ocorreu no dia 08 de janeiro de 1993 com objetivo de discutir a programação visual (limitação de propagandas) na cidade. Durante essa reunião, segundo Isabel, “o senhor Yves informou que Tiradentes foi escolhida como cidade Museu para uma campanha publicitária a nível nacional e destacou o fundamental compromisso da comunidade em, de fato, a cidade corresponder ao que vai ser veiculado na televisão" (grifo nosso).

Além disso, o Festival Gastronômico tem sido realizado, em suas últimas edições com apoio da Rede Globo, sendo anunciado em propagandas freqüentes e nos programas Terra de Minas, MG TV e mesmo Jornal Hoje, que é de exibição nacional. O Festival de Cinema é 
realizado pelo Centro Cultural Yves Alves, que fundado em 1998, pertence à prefeitura municipal, mas tem total apoio da Fundação Roberto Marinho para execução de seus projetos.

\begin{abstract}
Ora a cidade histórica, assim como o monumento individual, é transformada em produto de consumo cultural (...), ora pode ser destinada a fins econômicos que se beneficiam simbolicamente de seu status histórico e patrimonial, mas que a ela não se subordinam. O primeiro caso vê, pois, a cidade patrimonial posta em cena e convertida em cena: de um lado, iluminada, maquiada, paramentada para fins de embelezamento e midiáticos; de outro, palco de festivais, festas, comemorações, congressos, verdadeiros e falsos happenings que multiplicam o número de visitantes em função da engenhosidade dos animadores culturais. (CHOAY, 2001:224)
\end{abstract}

O Largo das Forras como centralidade física e uma das principais centralidades imagéticas de Tiradentes (bem como espaço público propício) é a sede desses eventos. Chamamos aqui de centralidade imagética porque, como elucidou Cancline (1997:191), “o território da praça ou do museu torna-se cerimonial pelo fato de conter os símbolos da identidade, objetos e lembranças dos melhores heróis e batalhas, algo que já não existe, mas que é resguardado porque alude à origem e à essência”. O Largo possui símbolos do passado importantes como o Monumento Tiradentes, a ponte de pedra e o sobrado da prefeitura, bem como símbolos recentes que fazem referência à sua nova identidade - as charretes que carregam turistas, os restaurantes-cafés e os mobiliários temporários para eventos que se revezam no centro da praça.

Os tiradentinos perderam sua exclusividade no uso desse espaço central da cidade e, ainda que lhes seja permitido usá-lo, há sempre o incômodo "olhar do turista", a perda da privacidade e da tranqüilidade. Há uma dificuldade de conciliar a tradição com o espetáculo que o turismo pede (nos casos em que a população se rende a se apresentar para o turista), e há também uma grande diferença cultural entre os tiradentinos e os ETs quando se trata de lazer. Nesse momento o uso do espaço público para diversão passa a ser um território de disputas, como colocou o tiradentino Rogério Almeida: 
Agora o pessoal de fora também, implica muito com o povo daqui. É... essa questão da identidade... você quer fazer uma festa, o povo de fora manda baixar o som, porque fala que está incomodando. (...) Só que o de fora implica, justamente, com as épocas em que o povo daqui tem o direito de brincar um pouquinho. Por exemplo, carnaval é época de festa. Aí o povo daqui vai fazer os blocos tradicionais... domésticas, bloco da caveira, aquelas coisas nossas aqui né? O povo de fora chama a polícia porque tá incomodando, não sei o que... então aí, começam a ter os atritos. Aí os atritos são intensos. Mas ao mesmo tempo os de fora não são contra os que moram aqui, não são contra de repente ter um congado, de ter uma folia de reis. Não são contra. (In ZOLINE, 2007:157)

Os usos, bem como os contra-usos ${ }^{40}$ e os conflitos vão definir os lugares. Os lugares de memória são, em grande medida, representações dos grupos que se apropriam deles, uma espécie de materialização da identidade. Segundo Oliveira (2006),

grandes conceitos que informavam a construção das identidades culturais, como nação, território, povo, comunidade, entre outros, e que lhe davam substância, perderam vigor em favor de conceitos mais flexíveis, relacionais. Segundo Teixeira Coelho, as identidades, que eram achadas ou outorgadas, passaram a ser construídas. As identidades, que eram definitivas, tornaramse temporárias.

Há uma mudança cultural na qual a "lógica da identidade" é substituída pela "lógica da identificação". Segundo a autora, houve uma transferência "da estabilidade e segurança garantidas pelas identidades rígidas, à impermanência, mutabilidade e fluidez da identificação".

A identidade, segundo Woodward (200:08) é relacional, isto é, “depende, para existir, de algo fora dela". E, uma vez que não vivemos isolados, a identidade serve como uma espécie de demarcação que nos separa e nos difere do outro. As identidades mais marcantes no território tiradentino são aquelas que dividem os usuários pela origem: os ETs

\footnotetext{
${ }^{40}$ Leite usa o termo "contra-uso" para designar os usos orgânicos, não planejados e muitas vezes incoerentes com o uso pré-determinado como preferencial. Seria a tática (Certeau) associada a um espaço de poder (Zukin), o que a torna vernacular e constitui um contra-uso "capaz não apenas de subverter os usos esperados de um espaço regulado como de possibilitar que o espaço que resulta das 'estratégias', se cinda para dar origem a diferentes lugares, à partir da demarcação socioespacial da diferença e das ressignificações que esses contra-usos realizam”. (LEITE, 2007:215)
} 
(moram na cidade, mas não nasceram nela), os Minhocas (tiradentinos) e os Turistas (visitantes).

Já descrevemos neste trabalho o perfil dos ETs e dos turistas de Tiradentes, mas o mais difícil de se definir, o tiradentino, deixamos a cargo de Olinto dos Santos (In: ZOLINI, 2007:127), pois nada melhor que um tiradentino para descrever a si mesmo:

(...) Olha hoje... ser tiradentino é um pouco complicado né? Você tem em Tiradentes hoje... continua sendo uma cidade provinciana, pequena, interiorana e, ao mesmo tempo, uma ciadade cosmopolita. Então você tem duas coisas conflitantes. Ao mesmo tempo em que você está numa cidade bastante pequena e provinciana, você tem uma ligação com o mundo, né? A gente aqui tem contato com gente de todos os lugares, e culturas, e níveis sociais, e além disso a gente tem várias manifestações... e vários eventos que acontecem aqui como concertos de grandes pianistas, organistas, grandes músicos, festival de cinema com as novidades do cinema nacional, e várias outras coisas... cozinha internacional, com chef de vários lugares. Então a gente fica no meio, né? Com um pé na província e um pé no mundo. Talvez seja isso!

\subsection{UMA QUESTÃO DE VALOR: O LARGO COMO ESPAÇO LIMINAR}

Se é verdade que o patrimônio serve para unificar uma nação, as desigualdades na sua formação e apropriação exigem que se o estude, também, como espaço de luta material e simbólica entre as classes, as etnias e os grupos. (CANCLINE, 1994:97)

A relação social entre pessoas "de fora" e "de dentro" de qualquer grupo é sempre conflituosa por uma questão instintiva de auto-proteção de cada um dos grupos (determinados por essa exo-identidade ${ }^{41}$ ). Segundo Mary Douglas (1966) esse conflito ocorre por uma questão de ordem:

\footnotetext{
${ }^{41} \mathrm{Ou}$ 'hetero-identidades', que são as identidades definidas pelos outros. O oposto da 'auto-identidade'. (Simon, 1979:24)
} 
Douglas utiliza o exemplo (...) de nossa percepção sobre o que conta como sujo. (...) A sujeira é uma "matéria fora do lugar". Não vemos nada de errado com a terra que encontramos no jardim, mas ela "não está no lugar certo" quando a encontramos no tapete da sala. Nossos esforços para retirar a sujeira não são movimentos simplesmente negativos, mas tentativas positivas para organizar o ambiente (...). Assim as categorias do limpo e do não-limpo, tal como as distinções entre "forasteiros" e "locais" são produtos de sistemas culturais de classificação cujo objetivo é criação da ordem. (WOODWARD, 2000:47)

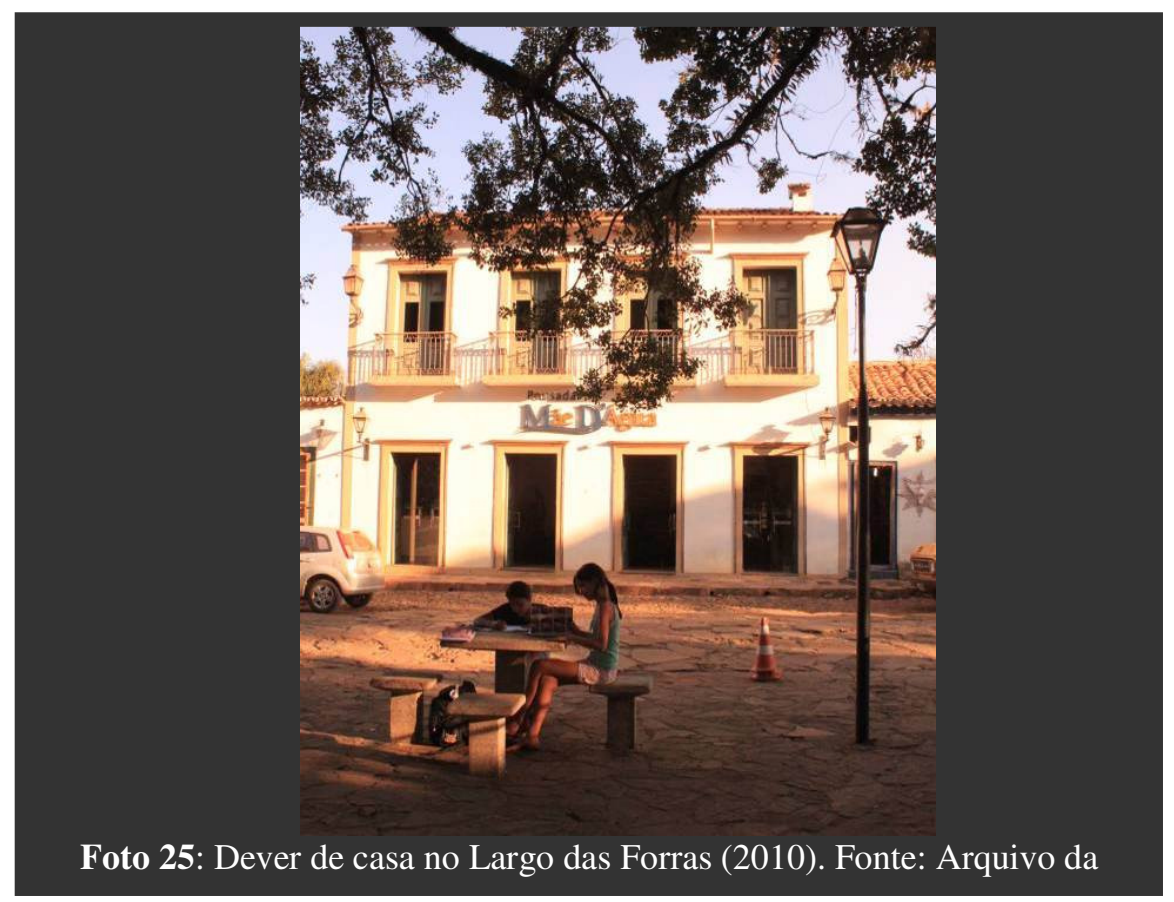

Essa relação precisa ser trabalhada, pois, no limite, gera xenofobia e conflitos diversos advindos da intolerância e da disputa por espaço e poder entre os grupos.

Uma das primeiras questões levantadas na introdução dessa dissertação foi quanto à apropriação do Largo. Ele seria patrimônio de quem?

O tombamento de um bem como patrimônio é uma ato de valorização que se dá depois da valoração (atribuição de valor) do objeto. Como já foi colocado no capítulo 1, o Largo foi tombado como espaço de valor estético, tendo o barroco e a arquitetura colonial como obras de arte, e também de valor simbólico para a formação da identidade nacional. Ele era um 


\section{patrimônio dos intelectuais modernistas, pois nesse momento foram eles que o valoravam e o consideravam patrimônio.}

A questão da atribuição do valor - que hoje nos aparece em toda sua complexidade - não parecia ser, no entanto, até há algumas décadas, uma questão controversa, nem digna de maior investigação: (...) a conservação constituiu durante muito tempo um campo relativamente fechado, sendo a atribuição de valor feita, via de regra, por experts que decidiam o que era (ou não era) patrimônio. (...) Nesse momento, a questão do patrimônio parecia de fato, adstrita a um pequeno grupo técnico, que compartilhava, a grosso modo, um mesmo universo conceitual e os mesmos valores, o que tornava supérflua qualquer discussão mais aprofundada nessa direção. (CASTRIOTA, 2009:100)

Mas e hoje, tanto tempo depois?

O processo de valoração dos bens (também conhecido como axiologia) tem se expandido e a matriz de valores possíveis se torna cada vez mais ampla. Como coloca Catriota (2009:101)

Esse quadro vai mudar substancialmente no final do século $\mathrm{XX}$, com a introdução de novos agentes no campo do patrimônio e com a crescente ênfase que se dá aos aspectos intangíveis dos bens culturais, fatores que também tornam cada vez mais necessário se explicar a operação de atribuição de valores sempre subjacentes no campo do patrimônio.

Para Meneses (1984) existem três razões para se preservar. A primeira razão seria científica (algo muito próximo do valor histórico de Riegl e documental de Fonseca) pela importância dos bens patrimoniais como fonte de compreensão dos fenômenos sócioculturais. A segunda, a afetiva, porque o patrimônio representaria um laço entre as pessoas e o espaço que materializa sua história. A terceira, política, seria uma razão para preservar os bens históricos e culturais como uma manifestação da cidadania e do direito amplo à polis.

Riegl, além dos clássicos Valores Artístico (Kunstwerte) e Histórico (Historischeswerte), criou também o Valor de História da Arte (Kunsthistorischeswerte), que ressalta a importância de se preservar mesmo as obras que não são bem aceitas pela vontade 
da arte na contemporaneidade, pois elas são relevantes como parte da história da arte, relatando as "vontades da arte" anteriores. O Valor Histórico (e de história da arte, que seria uma subdivisão dele) estariam dentro do que o autor chamou de Valores de Rememoração (Erinnerungswerte) que são aqueles que nos permite lembrar, o que dá substância à memória. Esse valor possui intrinsicamente valores cognitivos e políticos, na medida em que permitem conhecer o passado e reafirmar uma origem comum que reforça a ideia de nação. Desse valor poderíamos retirar, ainda, o "Valor de Rememoração Intencional", presente nos monumentos que são construídos para marcar uma época ou um evento - para deliberadamente não deixar esquecer.

Os Valores de Contemporaneidade (Gegenwartswerte) são muitos, já que incluem todos os valores que tem foco no presente. O Valor Artístico é um deles, já que a fruição é sempre presente. O Valor de Uso / Instrumental (Gebrauchswerte) define que um objeto, edifício ou bem imaterial tem valor de acordo com seu uso possível, sua adaptabilidade e função na vida contemporânea.

O Valor de Novidade (Neuheitswerte) busca atender a vontade da arte que nega os objetos ou edifícios muito envelhecidos, por vezes desmembrados. Esse valor entra em oposição direta com o Valor de Ancianidade (Alterswerte), que é a valorização do pitoresco, da "pátina do tempo" e a negação do restauro que coloca em um edifício antigo o aspecto de "novinho em folha". Ambos podem ser considerados parte do valor artístico e vão depender de opções estéticas individuais.

Um valor incluso no Valor de Uso, mas que hoje tem tamanha importância que deveria ser um valor à parte (até porque, dentro do binômio marxista uso/troca, ele é um valor de troca e não de uso) é o Valor Econômico, que em homenagem ao austríaco Riegl podemos apelidar de Wirtschaftswerte. 
Os valores estão intimamente ligados ao significado que os bens patrimoniais têm para cada pessoa ou grupo. Os edifícios, bem como o lugar em si (Largo), são símbolos. Tuan (1983:129) explica que "o símbolo é direto e não requer mediação lingüística. Um objeto se torna um símbolo quando sua própria natureza é tão clara e tão profundamente manifestada que, embora seja inteiramente ele mesmo, transmite conhecimento de algo maior que está além”.

Uma igreja tiradentina pode ser um espaço para realização de missas (funcional) no centro da cidade (referencial), uma obra de arte (estético) do estilo barroco (arquitetônico) representativa do período colonial (histórico), um espaço sagrado (cultural) e marcadamente tiradentino (identitário) onde ocorreram importantes eventos e fatos comunitários (afetivo). Um mesmo símbolo, portanto, pode ter múltiplos significados.

Para Umberto Eco (1971:113), “a relação entre um símbolo e seu significado pode mudar, crescer, deformar-se: o símbolo permanece constante e o significado torna-se mais rico ou mais pobre. Este processo dinâmico, contínuo, será chamado de sentido”.

Se os responsáveis pelas políticas de patrimônio descobriram há algum tempo a impossibilidade de se "congelar" os bens materiais, quem dirá seu significado, sua imagem e seu sentido - aspectos altamente intangíveis e fluidos. Para Choay (1995:03) “ele [o sentido] existe somente após uma apropriação ativa que é cada vez uma recriação".

O sentido de um bem é mais forte para uns, inexpressivo para outros. São os significados do bem (e não o bem em si) que criam o valor. Além disso a recepção dos bens tombados tem uma dinâmica própria em dois sentidos: primeiro no da mutabilidade de significações e valores atribuídos a um mesmo bem em diferentes momentos históricos - mudança que diz respeito inclusive às próprias concepções do que seja histórico, artístico, etc; segundo, no da multiplicidade de significações e de valores atribuídos, em um momento e um mesmo contexto, a um mesmo bem por grupos econômica, social e culturalmente diferenciados. (FONSECA, 2005:44)

O Largo das Forras, bem como todo o centro histórico de Tiradentes, tem um significado distinto para cada um que se apropria (ainda que de forma fugaz) dele. Há, 
contudo, alguns tipos de apropriação e valoração que podem ser generalizados em usos e significados coletivos. No caso do Largo os principais grupos que se apropriam de forma específica e atribuem valores coletivos ao espaço são os tiradentinos, os Ets e os turistas.

A questão da apropriação do centro histórico pelos ETs através da compra de imóveis é vista por muitos autores como um demonstrativo de que a cidade passou por um processo de típico de gentrificação.

Para preservar o que considera patrimônio histórico, dentro do modelo econômico capitalista, muitas vezes é necessário suprimir usos e população e inserir novos usos e público economicamente mais valorizados. Com isso desvinculam-se modos de vida e forma urbana: o chamado patrimônio histórico é esvaziado de sua urbanidade e reapropriado por atividades como shopping centres, lojas, centros culturais, museus e habitações de melhor padrão econômico. (MOREIRA, 2004:61)

Há, contudo, especificidades que não podem ser ignoradas. O estudo de Campos (2006) mostrou que, apesar de haver ampliação da periferia, a cidade não se tornou polinucleada, concentrando ainda toda sua vitalidade no centro histórico. Zoline (2007), por sua vez, acredita que as casas temporárias e os comércios tenham transformado o centro histórico em um espaço de gentrificação intermitente, no sentido de não possuir uma apropriação contínua.

Olinto dos Santos ${ }^{42}$ concorda que o uso predominantemente comercial esvaziou um pouco o centro. Mas lembra que pela característica dos lotes (compridos) existe ainda hoje pessoas que moram nos fundos dos empreendimentos. Como a maior parte desses proprietários são os ETs, ainda que não esteja esvaziado fisicamente, pois mantem os usos residenciais, o centro foi esvaziado do significado que os tiradentinos e seus laços com o cotidiano imprimiam a ele.

As ruas coloniais ainda estão impregnadas na memória do morador de Tiradentes, as igrejas continuam a ser referências urbanas marcantes, as festas religiosas ainda acontecem e as instituições públicas permanecem

${ }^{42}$ Entrevista realizada em 09/03/2010. 
instaladas ali, porém, o Centro Histórico não é mais o local da habitação, do cotidiano para a maior parte da população de Tiradentes. Uma parte de sua centralidade, portanto, se perdeu. (GOMES E LUSTOZA, 2009:11)

Gomes e Lustoza (2009:14) defendem, ainda, a tese de que o centro histórico mantém hoje uma centralidade política (com a prefeitura, câmara, Iphan e polícia), econômica (com os equipamentos turísticos) e imagética (história, lugar dos antepassados e dos símbolos), mas perde gradativamente sua centralidade social.

A substituição das velhas classes populares e pequeno-burguesas por novas classes ricas provoca verdadeiras falsificações não só porque os edifícios são geralmente esvaziados, reduzidos a simples fachada, reestruturados em seu interior, mas também porque as próprias classes originais constituem um bem cultural que deveria ser protegido. (ARGAN, 1998:79)

A pesquisa de Araújo (2004) ressalta que em Tiradentes alguns moradores deixaram suas casas no centro por não conseguirem arcar com os custos do patrimônio, como colocou o entrevistado N.25 “o patrimônio influência [na vida] porque a gente é pobre. Dá uma goteira, não pode mexer no telhado. O ruim é isso, a gente não tem quem dê uma ajuda. O patrimônio vem logo... a tal Isabel” ou o depoimento do entrevistado N.125 "Estava difícil conservar a casa no centro histórico e o patrimônio não ajudava. Na época mandei uma carta para o Rio de Janeiro e ninguém veio ver. Aí vendi e me mudei pra cá”.

A valorização dos imóveis também foi um fator decisivo.

Segundo reportagem da revista Veja, de fevereiro de 2002, $80 \%$ do casario do núcleo histórico de Tiradentes pertence aos "ETs" (extratiradentinos), onde a valorização dos imóveis aumentou $400 \%$ em 10 anos, sendo que a maioria não é mais de uso residencial (EDWARD, 2002:74 apud CAMPOS, 2006:149) 
Algumas pessoas optaram por vender ou alugar suas casas para aproveitar a valorização. Segundo Olinto dos $\operatorname{Santos}^{43}$, com o valor que se obtinha com a venda de uma casa no centro era possível comprar uma para cada filho na periferia.

Essa opção por se retirar do centro para obter melhores vantagens financeiras contrabalanceia com os casos em que os moradores foram impelidos a se desfazer de suas casas por não poder arcar com os custos. Foram encontrados muitos relatos de moradores que preferiram se mudar pelas vantagens de ter mais espaço, menor custo de manutenção e um grande lucro com a venda do imóvel antigo, como mostra o depoimento de D. Francisca Rocha:

Aqui mudou muito, melhorou muito, pois há quarenta e três anos era uma miséria, uma pobreza. Eram os casarões caindo, não tinha condição. Muitos moradores venderam suas casas por não terem condição de reformar, por ser patrimônio. A gente que é pobre preocupa-se com a economia, quer colocar tudo mais barato: porta de vidro, mas o patrimônio não deixa. Os turistas foram comprando, reformando. Hoje Tiradentes é melhor. Dizem, eu não lembro, que aqui tinha muitos casarões. Foram caindo e agora não, graças a Deus, o turista deu vida a Tiradentes. Ninguém expulsou ninguém. Eu não tinha condição e fiz a melhor coisa, estou no lugar que eu gosto. (In: SOUZA, 2004:14)

Frota (2005:117) também afirma que a população saiu ganhando, pois, segundo ela, "a vocação da cidade para o turismo cultural não só impediu o êxodo dos moradores para grandes centros urbanos, como, em vários casos, fez com que retornassem a ela indivíduos que já haviam migrado".

A pesquisa de Araújo mostra que materialmente a população não perdeu muito, já que a grande maioria (85,9\% dos entrevistados) mora em casas próprias e 14,8\% destes têm ainda um segundo imóvel alugado na cidade (gráfico 01).

Dentre os $28,9 \%$ de entrevistados que residem a pouco tempo na atual moradia (o restante diz ter sempre vivido na mesma casa), apenas um terço deles morava no centro

${ }^{43}$ Entrevista realizada em 22/10/2010. 
histórico anteriormente, tendo os demais vindo de outras cidades da região - o que demonstra um outro problema levantado em entrevista com Sr. Olinto, que é a imigração de pessoas da região em busca de trabalho.

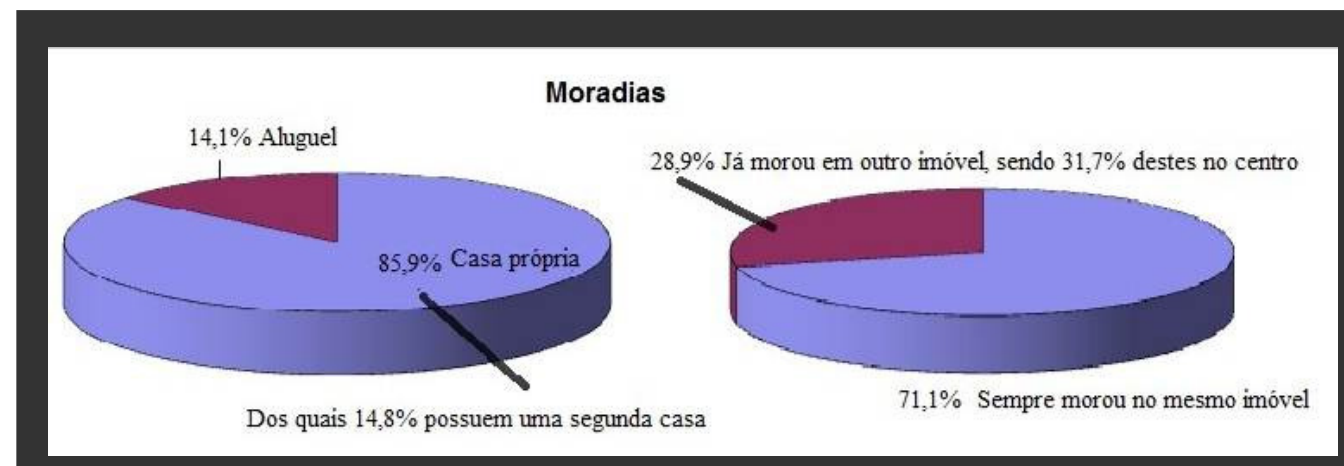

Figura 09: Resultados da Pesquisa de Araújo (2006). Fonte: Gráfico da autora (2010).

A valorização do imóvel também pode se tornar um problema de espólio, pois, por mais que um dos herdeiros queira manter a casa dos pais, dificilmente ele terá condição de comprá-la dos irmãos. Esse problema tem mantido a Casa de José Wiermann no Largo das Forras residencial e tal qual foi construída na década de 1960, já que os herdeiros não conseguem chegar a um consenso sobre o destino que darão ao imóvel. Foi um problema enfrentado também pelo historiador e vereador Rogério Almeida que relatou que

(...) o centro histórico hoje você pode dizer que é um parque temático. Não é mais da população. A população hoje tá no entorno. Eu mesmo... minha mãe faleceu tem 2 anos, eu tive que vender. Eu e mais 3 irmãs colocamos a casa da minha mãe a venda. Foram 400 mil reais, 100 mil reais pra cada filho, pelo fato de que ninguém tinha condição de comprar a casa do outro...." (in: ZOLINI, 2007:127)

Mas há ainda famílias tiradentinas que resistem e habitam o centro histórico, como mostra este depoimento: 
Gosto muito daqui, tenho vizinhos, amigos. Atualmente as pessoas mudaram. Foram saindo aos poucos. Os turistas compraram os imóveis, as pessoas venderam iludidas, mas depois se arrependeram. Minha vizinha se arrependeu. Já recebi proposta de um senhor de Belo Horizonte que tem loja aqui perto. Quis alugar minha sala, mas não aluguei. Perguntei a ele: $\mathrm{O}$ senhor viu alguma placa de aluga-se? Ele disse que iria conseguir alugar uma casa nesta rua, mas a minha ele não consegue!(D. ${ }^{a}$ Maria José Moura Nascimento de 73 anos In: SOUZA, 2004:13)

Contudo, o mais comum hoje é o uso do centro histórico pelos tiradentinos como local de trabalho. Na maior parte das vezes, como colocou Rogério Almeida, os negócios pertences aos ETs e os “minhocas” são funcionários. Em suas entrevistas, Márcia Araújo (2004:97) encontrou depoimentos de influência do patrimônio no local de trabalho, quase sempre apontadas como negativas por gerarem restrições. O entrevistado N.26 contou que "lá só tem um banheiro, o dono quis fazer outro, mas o patrimônio não permitiu" e o N.126 afirma que “teve uma reforma que foi embargada duas vezes" em seu local de trabalho.

A identificação do tiradentino com o patrimônio vai se tornando cada vez mais distante. O IPHAN, como muitos reclamaram, cobra da população posturas que ela não está preparada (tanto financeira quanto cognitivamente) para atender. Como resultado, a pesquisa de Araújo (2006:43) apontou que apenas 7,1\% dos entrevistados acham que vale a pena preservar o patrimônio por motivos afetivos - número muito próximo dos que acham que não deve ser preservado ou não sabem indicar um motivo para que seja preservado $(6,3 \%)$ e muito inferior aos que citaram motivos econômicos e estéticos para manutenção dos edifícios $(47,2 \%)$.

No caso do Largo das Forras a dinâmica de ocupação pelos ETs foi muito diferente do restante do centro histórico. Provavelmente por ter uma formação mais recente (com os últimos vazios ocupados na década de 1970) e por ter sido apropriada por famílias locais abastadas e influentes nos últimos cinquenta anos. No Largo das Forras hoje não existem 
proprietários extra-tiradentinos, apesar de alguns empreendimentos serem geridos por eles por contrato de serviço ou aluguel dos imóveis.

Francisco Barbosa foi uma personagem marcante para a construção do atual Largo das Forras, já que construiu uma casa para sua família por volta de 1950 ( $1^{\circ}$ andar do atual sobrado Barbosa, com construção do segundo andar em 1969), um correio em 1957 (atual Oficina de Ourivres) e, durante seu mandato de prefeito em 1961, comprou o casarão dos Paulucci e transferiu a prefeitura para o Largo das Forras. É citado por Lélia Frota (2005:111) como "prefeito esclarecido" em reconhecimento a sua contribuição, como por exemplo o fato de que ele "com pequena ajuda do Patrimônio calçou Tiradentes com as lajes que ela hoje mostra" ou conseguiu, a pedido de Tancredo Neves, então deputado, a casa da Rua Padre Toledo N. 8 para sede da Fundação Rodrigo Melo Franco de Andrade. Atualmente seus herdeiros Nilson, Nilberto, Nilder e Nilzio são proprietários de mais da metade dos imóveis da praça (figura 09), sendo que este último é atualmente prefeito da cidade.

Essa realidade demonstra, mais uma vez, a especificidade deste espaço dentro da dinâmica geral do município. Sua tardia apropriação por um grupo mais influente de moradores e sua viabilidade financeira propiciadas pela maior flexibilidade ${ }^{44}$, centralidade e turistificação do espaço, fizeram do Largo das Forras um reduto de poucas famílias tiradentinas influentes dentro de um centro histórico que pertence predominantemente aos ETs.

Se, por um lado, a permanência dos moradores locais é uma especificidade que desqualifica a adjetivação de "gentrificado" ao Largo, observa-se, contudo, outras características do processo de gentrificação presentes no Largo.

Zukin identifica, assim, duas características das políticas de gentrification: "centralidade" e formação de "paisagem do poder". O primeiro processo

\footnotetext{
${ }^{44}$ Como poucos imóveis são realmente antigos, as mudanças foram mais intensas e menos reprimidas pelos
} órgãos de proteção ao patrimônio. 
refere-se a reapropriação de certos espaços da cidade, a partir da concentração de atividades que refazem os usos e impõem uma visão que culmina com a apropriação espacial. A conseqüência da formação de uma centralidade é quase sempre a formação de uma "paisagem de poder" para designar uma forma socioespacial de assimetria do poder. (LEITE, 2007)

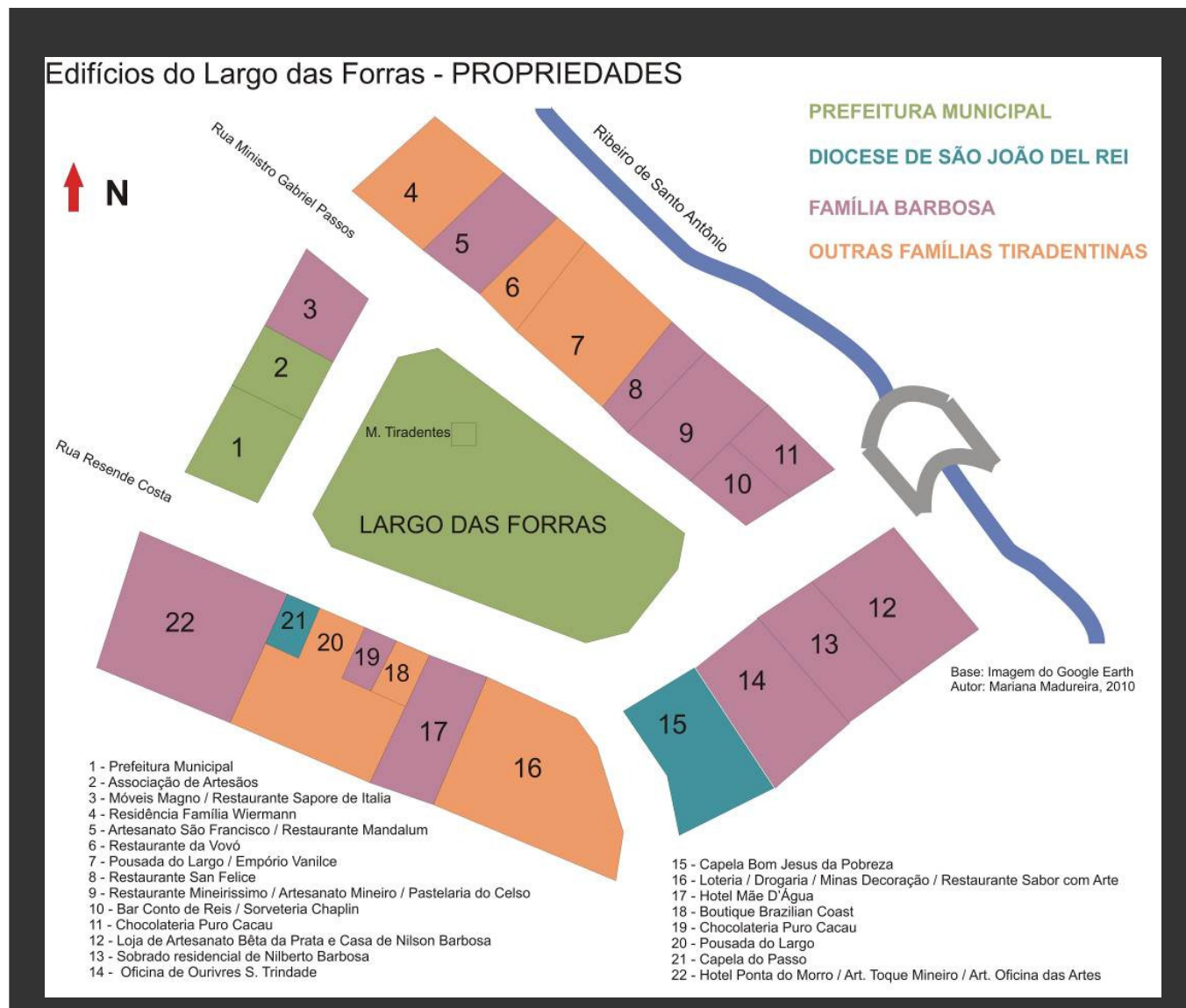

Figura 10: Propriedade dos imóveis do Largo das Forras (2010). Fonte: Ilustração da autora.

Podemos, afirmar que em relação ao Largo das Forras houve sim um enobrecimento e valorização do espaço, houve a criação de uma centralidade e a formação de um "espaço de poder". Não podemos, contudo, chamar o processo de gentrificação (ao menos no sentido social) por não ter gerado (nesse espaço específico) a substituição da população e também pelo fato de que essas transformações não foram resultados de uma política direcionada ou 
projeto pontual (como os processos de gentrification geralmente são), mas de iniciativas públicas e privadas não coordenadas e diluídas ao longo de meio século.

Os proprietários dos imóveis do Largo das Forras resistiram e permaneceram mesmo depois da chegada dos ETs, do turismo e dos Festivais. Mas em relação à apropriação cotidiana do Largo, o mesmo não ocorreu. Mesmo quando não estão ocorrendo eventos, o Largo é frequentado atualmente predominantemente por turistas.

À exceção das igrejas, que ainda fazem parte do cotidiano do tiradentino devido à forte presença da religião na cidade, há poucos espaços de socialização no Centro Histórico. O tamanho pequeno da cidade é um facilitador para a vida social, mas, mesmo que se note a presença de muitos moradores no Largo das Forras, por exemplo, eles ficam sujeitos a levas constantes de turistas que se avolumam no local. O campo de futebol Aimorés e a Quadra Poliesportiva Municipal no Bairro Parque das Abelhas são as únicas opções próximas para prática de esporte. Os equipamentos e atividades culturais ainda têm uma tímida participação da população local. (GOMES E LUSTOZA, 2009:14)

Há indícios de que o Largo esteja sendo cada vez menos freqüentado pelos tiradentinos. A principal causa desse "abandono" são os preços praticados nos estabelecimentos e a progressiva falta de identificação do cidadão com espaço.

A maioria dos restaurantes na praça eram casas. Hoje tem muitos restaurantes, empregos. Aqui falta uma área de diversão para os jovens. Restaurantes e barzinhos são muito caros, nós do lugar não podemos dar este luxo de comer e beber, não podemos pagar. Aqui já teve baile, ambiente familiar. Todo mundo podia entrar (jovem, criança, idoso). O jovem hoje chega à noite, faz o quê? (D. ${ }^{a}$ Francisca Maria Rocha - ex-moradora do Centro Histórico, atual moradora da Mococa. In: SOUZA 2004:14)

Há, contudo, uma resistência e um uso remanescente do Largo por, sobretudo, famílias com crianças. Segundo a pesquisa de Araújo (2004:98) brincar no Largo das Forras corresponde a $12,5 \%$ e conversar no Largo das Forras 4,1\% das atividades de lazer praticadas pelos entrevistados, segundo eles próprios. Apesar dessa tendência à desapropriação pela população, somada a resposta "passear pelo centro histórico", já que ele está dentro do mesmo, o Largo das Forras ainda é usado por 33,4\% dos entrevistados como espaço de lazer. 
O alto custo do lazer atualmente aparece no comentário de Lélia Frota (2005:151) sobre o uso do espaço urbano pelo tiradentino jovem, indicando que ele favorece a apropriação do Largo por falta de opção: "E a mocidade, vai à boate e conversa nos bares. Quem tem pouco dinheiro, ainda se encontra no Largo das Forras.”

O resultado encontrado por Márcia Araújo nos remete à resistência da população local encontrada por Rogério Leite (2007) em sua pesquisa no Bairro do Recife. Ele relata que no espaço estudado

Mesmo subtraindo ao usuário (principalmente moradores antigos) o que passou a apresentar a observadores (Certeau, 1998:195) a desapropriação de sujeitos não implicou a supressão de uma vida pública. O modo como esses observadores passaram a interagir com esses marcos enobrecidos fez subsistir uma sociabilidade pública, ainda que marcada por uma nova lógica interativa, construída à partir de demarcações socioespaciais da diferença, que resultaram em atos (públicos, coletivos ou não) de apropriação de lugares.

Everaldo Costa (2007:11) identifica “um único projeto de interação social desenvolvido pela prefeitura: o Brincando na Praça, que tem por objetivo direcionar a população da periferia para o Largo das Forras, ponto de encontro dantes exclusivamente dos residentes, agora, tomado pelos visitantes".

Costa (op cit) acredita que apesar do IPHAN afirmar em seu Projeto Piloto de 1997 que "as intervenções urbanas devem priorizar a melhoria da qualidade de vida da população local", o que se faz na prática ainda é predominantemente a favor da preservação do espaço físico, sem ações significativas para empoderamento e inclusão da população local.

Segundo Rogério Leite (2007:292)

as demandas de pertencimento, condição necessária para o exercício de uma cidadania plural, refazem os nexos entre o patrimônio-relíquia [distante] e os lugares, conferindo sentido aos espaços enobrecidos da cidade. Quando as práticas de gentrification 'estriam' áreas de patrimônio para as demandas de mercado, criando lugares de consumo, a única maneira de interagir com esses espaços é igualmente por meio da construção de outros lugares, que possibilitarão ancorar os usos e contra-usos. 
Há claramente disputas e fronteiras no espaço do Largo. Sejam elas econômicas (impedindo que a população local de baixa renda utilize dos serviços ofertados), culturais (que disputam o uso da praça), marcadas pela posse (e rixas) de diferentes famílias, ou de outra natureza.

Deve-se considerar, contudo, que essas fronteiras não existiram sempre e não são estanques e imutáveis. Muito pelo contrário, são fluídas e transmutáveis, nas palavras de Antônio Arantes (1994:191), são “zonas simbólicas de transição construídas continuamente”.

A reformulação do patrimônio em termos de capital cultural tem a vantagem de não representa-lo como um conjunto de bens estáveis e neutros com valores e sentidos fixados de uma vez para sempre, mas como um processo social que, como o outro capital, acumula-se, reestrutura-se, produz rendimentos e é apropriado de maneira desigual por diversos setores. (CANCLINE, 1997:193)

Após esses três anos de pesquisa o que se percebeu é que o Largo das Forras são vários patrimônios que pertencem a grupos distintos que o usam e o valorizam de forma distinta.

É um lugar de memória e um patrimônio afetivo para aqueles que foram criados na cidade e relacionam os espaços às suas experiências passadas e a de seus entes queridos. Esse valor fica claro quando Rogério Almeida (In: BOLSON, 2006), perguntado sobre as transformações urbanas na última década admitiu que "essas mudanças doem, essa perda de identidade", e acrescentou: "Queria que meus filhos vivessem no centro histórico como eu vivi, mas a questão financeira fala mais alto."

Representa a oportunidade de ter uma melhor qualidade de vida (pela tranquilidade da cidade) aferindo bons lucros (com a atividade turística) para os ETs que migraram para lá. Para esse grupo o Largo das Forras significa viabilidade para concretização dessas aspirações (apesar de não serem proprietários, como já colocado), sendo portanto, predominantemente, um valor de uso/instrumental/econômico. 
É um legado artístico e cultural para aqueles que se interessam por história, arte e arquitetura, pois possui, nas palavras de Choay (2001:228) um "valor intelectual e estético".

É um lugar de lazer e consumo para o turista que procura entretenimento. Proporciona bons momentos pela beleza, serviços, tranquilidade, rusticidade e sua aura de lugar de memória. A legitimidade dos valores históricos e artísticos não costuma importar, pois para a maior parte desse grupo a função desse espaço é propiciar o prazer. 


\section{CONCLUSÃO - O LARGO DAS FORRAS HOJE}

As cidades como os sonhos, são construídos por desejos e medos, ainda que o fio condutor de seu discurso seja secreto, que as suas regras sejam absurdas, as suas perspectivas enganosas, e que todas as coisas escondam outra coisa... De uma cidade, não aproveitamos as suas sete ou setenta e sete maravilhas, mas as respostas que dá às nossas perguntas.

(CALVINO, 1990).

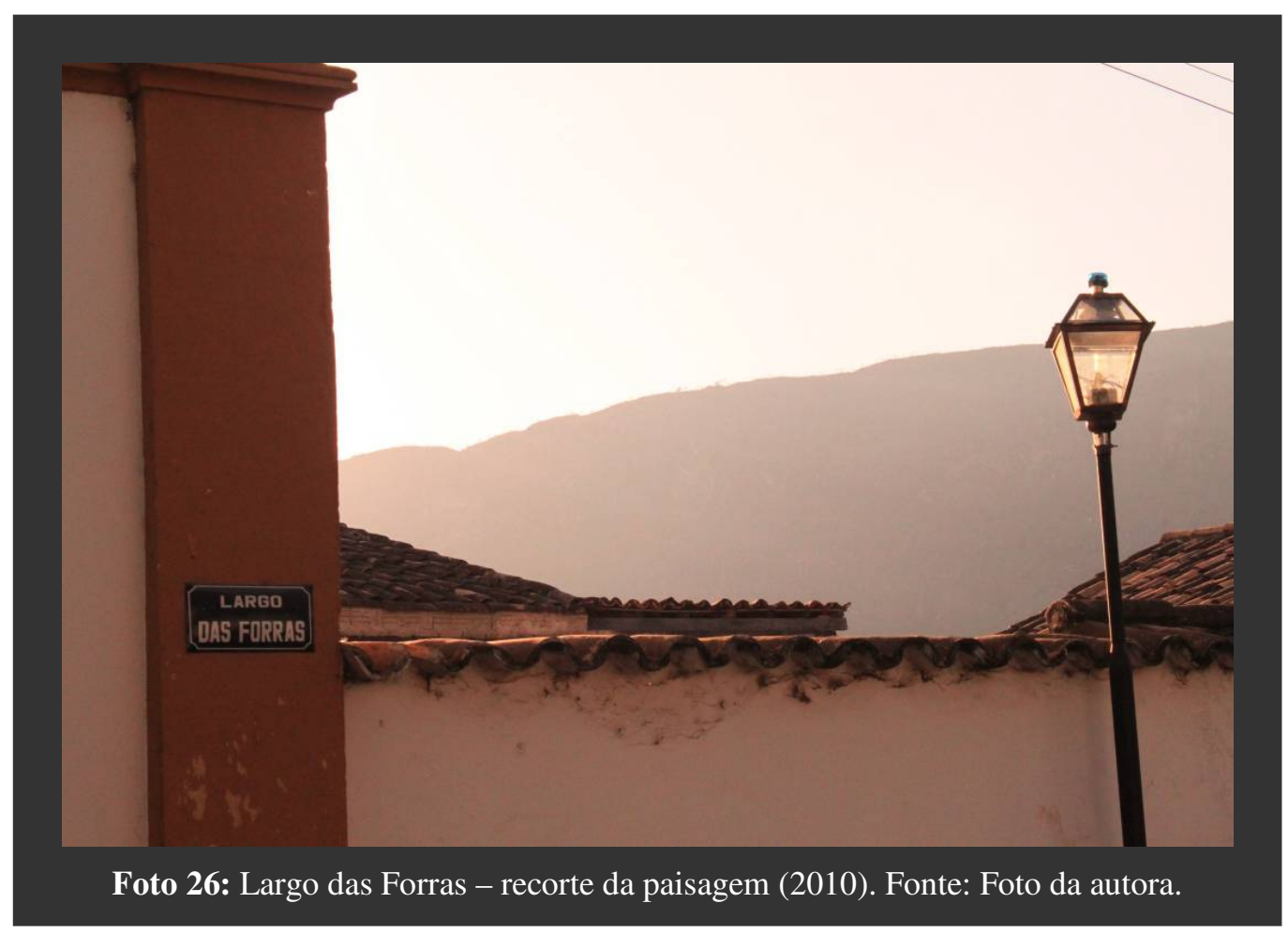

A construção de um lugar de memória envolve, antes de mais nada, escolhas. O Largo das Forras foi escolhido em 1938, provavelmente, por sua nova centralidade geográfica naquele momento (tendo em vista a expansão urbana - figura 03), pela existência de alguns exemplares coloniais (que eram o símbolo da identidade nacional) e pelo formato do Largo, favorável à apropriação como espaço público - o que já ocorria de forma mais incipiente e menos programada desde o século XIX. 
Hoje ele pode ser considerado um lugar, ou lugar de memória, por ter sido capaz de acumular

os elementos tangíveis (edificações, sítios, paisagens, rotas, objetos) e intangíveis (memórias, narrativas, documentos escritos, rituais, festivais, conhecimento tradicional, valores, texturas, cores, odores, etc), isto é, os elementos físicos e espirituais que dão significado, valor emoção e mistério para o lugar. (ICOMOS, 2008:03 In: CASTRIOTA 2009:103)

Ecléa Bosi (1971:07) define a memória como um “trabalho", na medida em que é um processo permanente de adições, construções e alterações.

No Largo das Forras convivem sistemas técnicos ${ }^{45}$ diferentemente datados, isto é, elementos provenientes de épocas diversas. A paisagem, grande palimpsesto, é emoldurada pela Serra de São José e apresenta as opções de permanência (como a capela de Bom Jesus) e de abandono (como o grêmio recreativo e o salão de baile); de refuncionalização de formas antigas (prefeitura) e de invenção de formas novas (galpão dos artesãos); da opção pelo mimético (Bêta da Prata) à opção pelo distinto (Sapore d'Itália); manutenção de fachadas (ou parte dela) com novo interior (Hotel Ponta do Morro), entre outros. Uma complexidade que exige que assim se considere ao pensar sua gestão.

O conjunto urbano é um tipo diferente e particular de objeto patrimonial que exige procedimentos próprios de... preservação. A simples proibição de alterações e o cumprimento de normas de intervenção não é suficiente, pois a área urbana - patrimônio é, antes de mais nada, um fato sócio-econômico que possui uma dinâmica própria e depende de muitos outros fatores para manter-se preservada (SANT'ANNA, 1996).

A gestão do patrimônio em Tiradentes deve ir além da sua concepção e preservação como monumento (paradigma do tombamento no início do século) ou como instrumento (paradigma vigente), como refletiu Leite (2007:21):

\footnotetext{
45 "As técnicas são um conjunto de meios instrumentais e sociais, com os quais o homem realiza sua vida, produz e, ao mesmo tempo, cria espaço" (SANTOS, 1997:25) Segundo o autor, a técnica é como se fosse o tempo congelado, de modo que revela uma história.
} 
Ambas as formas de intervenção, seja a que se apóia na discutível idéia de uma memória nacional (ou local), seja a que se orienta pela não menos discutível lógica do consumo, são formas igualmente seletivas de intervenção e apropriação simbólicas, construídas a partir de determinadas concepções sociais: uma supõe eficaz uma memória compartilhada para ações convergentes no interior de uma nação (ou de uma localidade que a represente), outra canaliza o valor potencial de ações de consumo no interior do mercado cultural.

A realidade é que apesar de termos avançado em técnicas, critérios e legislação de proteção, uma política de patrimônio não é capaz de gerar autenticidade ou recuperar tradições. Como colocou Certeau (1998:190), “os produtos que saem da restauração estão [sempre] comprometidos" uma vez que é impossível restaurar (no sentido de re-instaurar) em um bem suas qualidades artísticas, seu valor histórico-documental e o seu significado através de intervenções arquitetônicas. O resultado é que "as 'velhas pedras' renovadas se tornam lugar de trânsito entre os fantasmas do passado e os imperativos do presente".

Melo (1998:22) explicita, ainda, o teor ilusório da categorização de uma política de patrimônio como ferramenta capaz de atender ao interesse público. Segundo a autora o engano tem duas raízes: a primeira está na crença de que o Estado (neste caso os órgãos de patrimônio) teria a capacidade de representar todos os mais diversos interesses, ou tivesse legitimidade de escolher entre eles, "como se o saber técnico pudesse se colocar acima de interesses específicos de grupos"; a segunda fonte de engano é a "crença de que as relações entre grupos e classes sociais são pautadas por consenso ou pelo contrato social”. O Estado não é autônomo diante dos cidadãos e os cidadãos não possuem um consenso do que seja preservação. "Assim a política pública é uma opção por determinada visão de bem cultural, assim como envolve uma escolha a respeito de alocação de recursos e interesses concorrentes".

"O patrimônio Histórico é uma vertente particular da ação desenvolvida pelo poder público para a instituição da memória social. O patrimônio se destaca dos demais lugares de memória uma vez que o reconhecimento oficial integra os bens a este conjunto particular, aberto às disputas econômicas e 
simbólicas que o tornam um campo de exercício de poder." (RODRIGUES. 1996:195)

No caso de Tiradentes esse problema é reforçado pela total falta de articulação entre IPHAN, IEPHA e Prefeitura Municipal (GIOVANINNI JR, 2002:38). No caso da Prefeitura, além da desarticulação com os demais órgão envolvidos na gestão do patrimônio, pesa a falta de organização e planejamento ${ }^{46}$.

Tem três anos a nova gestão. O político é muito forte. Apagaram todos os computadores, todas as informações, não tinham relações de pousadas, não tinham listas de reclamações de turistas e os computadores não estavam funcionando. Chegaram a nova administração praticamente sem nada. (Entrevista do secretário de Turismo, Meio Ambiente e Cultura, Almir Ernani, a Fernanda Lima, 2008:259) / As pousadas que apoiam o prefeito não pagam impostos. (...) Então existe uma política de clientelismo mesmo!! (Outro entrevistado de Lima que preferiu não ser identificado, 2008:263)

Diante dessa constatação de impotência e de impossibilidade de livrar o patrimônio de todos os problemas apontados ao longo dessa dissertação através de alguma política pública de preservação, resta-nos apenas nos abster de dar sugestões ou possíveis soluções e concluir este trabalho com algumas reflexões.

A primeira é em relação aos impactos do desenvolvimento turístico no patrimônio e na vida da cidade. Não faz sentido insistir em extremos como afirmar que o turismo é totalmente bom ou ruim, benéfico ou prejudicial à cidade, essencial ou dispensável, e assim por diante. As inúmeras possibilidades de intervenção e graus de turistificação, bem como as diversas realidades específicas, nos obrigam a interpretar esse fenômeno de forma mais ampla e dialética, referenciando à lingüista, de forma adversativa:

\footnotetext{
${ }^{46}$ Lima (2008:192) expõe as possíveis origens do problema ao relatar que apenas $1 \%$ dos funcionários da prefeitura é contratado (todo o restante estatuários) e apenas 5\% tem curso superior completo, sendo que mais da metade tem apenas o ensino fundamental (dados de 2001), além de problemas como a falta de informatização das informações de interesse público e a dificuldade de acesso às mesmas, a inconstância dos conselhos de turismo e de cultura (bem como a inexistência de conselhos de desenvolvimento urbano), além de outros fatores, sobretudo de influência político-partidária.
} 
A turistificação melhora a qualidade do espaço, mas tende a excluir a população original dos mesmos - como ocorreu no centro histórico de Tiradentes;

Permite novas possibilidades de emprego e renda, no entanto, relega à população local os sub-empregos, quando não a informalidade - no caso do centro histórico de Tiradentes, diferente do Largo das Forras, a grande maioria dos empreendimentos pertencem aos ETs que empregam os minhocas nas condições de trabalho mais variadas;

Cria melhores condições sanitárias, de infra-estrutura e segurança, porém gera efeitos perversos como o aumento do custo de vida, especulação imobiliária e aumento da violência - em Tiradentes a infraestrutura melhorou muito e o custo de vida aumentou de forma exorbitante. Quando ocorrem os grandes eventos é comum ouvir reclamações dos moradores em relação a barulho, bagunça e violência;

Financia a preservação do patrimônio através dos projetos de restauração e dos lucros obtidos com a visitação, todavia, transforma o patrimônio em mera mercadoria da indústria cultural - em Tiradentes o casario se encontra, de modo geral, em excelente estado de conservação, sua função e significado são, contudo, cada vez mais comerciais;

Valoriza a cultura local e aumenta a auto-estima das comunidades, contudo, desfaz ou recria a memória e os laços de identificação com o lugar, estetizando o patrimônio - o tiradentino tem muito orgulho de ter uma cidade bonita e cobiçada pelos turistas, mas também tem cada dia mais dificuldade de contar a história daquela cidade e de relacioná-la com sua história pessoal.

Essa reflexão resume, ainda que não conclua, os impactos do turismo no lugar, e o relativismo desse impacto nos faz pensar o turismo como atividade complexa que não deve ser banalmente condenada, nem inconsequentemente apoiada (COHEN, 1988:384).

A segunda reflexão envolve dois aspectos presentes no Largo e pré-concebidos como negativos: a predominância do "estilo patrimônio" (que é um falso histórico) e o processo de 
gentrificação (que, ainda que 'incompleto' ou 'interminente', modificou, enobreceu e estetizou o espaço).

Perguntado sobre a possibilidade da arquitetura mimética mais recente da cidade induzir ao erro, Sr. Olinto Santos respondeu que quem entende de arquitetura colonial sabe diferenciar o que é novo do que é original. Então indagamos: mas e a grande maioria, que não entende? E a resposta foi: "pra esses tanto faz o centro histórico ou a pequena Tiradentes da Vanilce [se referenciando a uma réplica da cidade em miniatura que uma empreendedora local construiu em sua pousada], eles não se preocupam com isso". Se encontram na categoria definida por Fiefer (1985 apud FEATHERSTONE 1995:138) como pós-nostálgicos ${ }^{47}$

(...) platéias cada vez maiores de uma classe média desejosa de ter experiências com um jogo cultural, que renunciou a ir ao encontro do autêntico e do real, que se contenta em ser 'pós-turista', aprecia a reprodução do efeito do moral, a imersão nele, de maneira controlada ou lúdica, e o exame daquelas regiões que se situam nos bastidores de um palco em que este real se apóia.

A afirmação de Olinto dos Santos Filho sobre o descomprometimento dos turistas com a "autenticidade" (que, enfim, não se pode dizer que exista na atual ausência de um conceito concreto $^{48}$ e com a história nos remete à conclusão de Robert Venturi ${ }^{49}$ que gerou polêmica ao afirmar no New York Times que a Disney estava muito mais próxima do que as pessoas queriam do que qualquer outra proposta arquitetônica conseguiu chegar. Não estaria ele certo?

A Tiradentes que vemos hoje não está muito mais próxima da “cidade presépio" e “cidade museu" que os turistas, os empreendedores e a mídia querem do que uma proposta conservadora de preservação total (que impedisse acréscimos, preenchimento de

\footnotetext{
47 Ou, na categorização de Cohen (1988:377), turistas experimentais, recreacionais e diversionários. Schutz (1979) problematizou as relações entre turistas e suas experiências. Vistas, por sua velocidade e fluidez, como relações superficiais, o autor realça que "o turista viaja por um plano da realidade que não é falso, inautêntico ou mentiroso; apenas diferente, com um estilo cognitivo especial que o distingue da realidade da vida cotidiana".

${ }^{48}$ A grande relatividade existente em torno do termo "autenticidade" não nos permite ainda usá-lo de forma legítima para qualificar bens patrimoniais, contudo, como coloca Choay (1995:05) "a noção de autenticidade poderia ter uma utilidade, prática, preventiva, mas unicamente para interpretação de sua antítese, a inautenticidade, no caso de falsos ou cópias deliberadas".

${ }^{49}$ Robert Venturi - New York Times, 22 de outubro de 1972 apud Harvey 1989:62.
} 
vazios, requalificações, etc) ou de laissez-faire (que permitisse um desenvolvimento orgânico) poderiam jamais ofertar?

Ainda na mesma perspectiva, em relação ao processo de gentrificação, não teriam razão Marques e Loureiro (2003:243) quando concluíram para a intervenção no Pátio São Pedro em Recife que: "Ora o que se evidencia na experiência internacional é: 'sem gentrificação não há sustentabilidade'." Não seriam essas mudanças e esse mise en valeur do patrimônio condições sin ne qua non para o desenvolvimento da cidade e preservação (ainda que parcial) de sua herança?

Como seria Tiradentes hoje se não houvesse o turismo, sua principal fonte de renda? E como seria criado um produto turístico atrativo se não houvesse uma refuncionalização que transformasse as velhas casas nos equipamentos que os vistantes querem usar e as fachadas nas belas edificações que querem ver?

É importante refletir, também, até que ponto o que chamamos pejorativamente de "descaracterização" não seria apenas "atualização", isto é, adequação dos objetos para o novo contexto. Neste sentido, Cacline (1997:301) escreveu: “sem vitrinas nem guardiões que os protejam, os monumentos urbanos são felizmente expostos a que um grafite ou uma manifestação popular os insira na vida contemporânea."

Não seria a atual ampliação do patrimônio cultural (e tentativa de proteção do mesmo) uma "pulsão museófila coletiva", um exagero que limita nossa liberdade, como colocou Jeudy (1990:15)?

Qual seria o problema em oferecer aos turistas o entretenimento que eles querem? E em oferecer aos empreendedores os lucros que eles almejam? Qual o problema em permitir às pessoas a apropriação e o uso do patrimônio que a atualidade e a vontade da arte pedem?

O grande problema é que os interesses muitas vezes não são conciliáveis. E, uma vez que algumas escolhas não podem coexistir no espaço, resta o grande desafio de gerenciá-las. 


\section{REFERÊNCIAS BIBLIOGRÁFICAS}

ALBANO, Celina; FREIRE, Doia. Projeto de Sinalização Interpretativa para a cidade de Tiradentes. Belo Horizonte, 1997.

ANDRADE, Mário de. Cartas de Mário de Andrade a Manuel Bandeira. Prefácio e notas de Manuel Bandeira. Organização Simões Ed, 1956.

ANDRADE, Rodrigo Melo Franco de. Rodrigo e o SPHAN. MinC / SPHAN / Pró-memória: Rio de Janeiro, 1997.

ARANTES, Antônio Augusto. A Guerra dos Lugares. In: Revista do Patrimônio Histórico e Artístico Nacional. Rio de Janeiro: n²3, 1994.

, Antônio Augusto. O Patrimônio Cultural e seus usos nas cidades contemporâneas. In: MORI; SOUZA; BASTOS; GALLO (org). Patrimônio: Atualizando o Debate. IPHAN: São Paulo, 2006.

ARAÚJO, Márcia Pereira. As Relações entre Comunidade Local e a Área Histórica de Tiradentes - MG: uma contribuição para a preservação do patrimônio cultural em áreas urbanos. Dissertação. Universidade Federal do Rio de Janeiro, 2004.

ARGAN, Giulio Carlo. História da Arte como história da cidade. Martins Fontes: São Paulo, 1998.

AUGÉ, Marc. Não-Lugares: Introdução a uma antropologia da supermodernidade. São Paulo: Papirus, 1994.

BOITO, Camillo. Os restauradores. [I restauratori: Conferenza Tenuta alla Esposizione di Torino il 7 giugno 1884 - Tradução Beatriz e Paulo Mugayar Kühl). Ateliê editorial. São Paulo 2002

BANDEIRA, Manuel. Guia de Ouro Preto. (1938) Ediouro, 2000.

BAUDRILLARD, Jean. Para uma crítica da economia política do signo. Lisboa: Edições 70, 1984. 
BOLSON, Janaína G; FERREIRA, Marta A T. Os Impactos do Turismo em Tiradentes: uma Análise da Percepção do Setor Público Local. Sem. de Pesq. em Turismo do MERCOSUL UCS, IV. Caxias do Sul, 2006.

BONELLI, Renato. Scritti sul Restauro e sulla Critica Architettonica. Roma, Bonsignori, 1995.

BOURDIEU, Pierre. A economia das trocas simbólicas. São Paulo: Perspectiva, 1999.

BRANDI, Cesare. Teoria da Restuaração. São Paulo, Ateliê Editorial, Coleção Artes \& Ofícios, 2004.

BRITO, Marcelo. Pressupostos da Reabilitação Urbana de Sítios Históricos no Contexto Brasileiro. São Paulo, Portal Vitrúvio/Arquitextos, 2003.

BURTON, Richard. Viagens aos Planaltos do Brasil: do Rio de Janeiro ao Morro Velho (1868). Ed. Nacional: São Paulo, 1991.

CALVINO, Italo. As cidades invisíveis. 2. ed. São Paulo: Companhia das Letras, 1990. 150p

CAMPOS, Helcio Ribeiro. Transformações urbanas recentes em Tiradedentes -MG: anos 80 e 90 do século XX. Dissertação de mestrado da Faculdade de Filosofia, Letras e Ciências Humanas. USP, 2006.

CAMURÇA, Marcelo; GIOVANINNI JR, Oswaldo. Religião, Patrimônio Histórico e Turismo na Semana Santa em Tiradentes. Horizontes Antropológicos, Porto Alegre, ano 9, n. 20 , p. 225-247, outubro de 2003

CANCLINI, Nestor Garcia. Culturas Híbridas. São Paulo: EDUSP, 1997.

CANCLINI, Nestor Garcia. O Patrimônio Cultural e a Construção Imaginária do Nacional. In. Revista do Patrimônio Histórico e Artístico Nacional, Rio de Janeiro, no 23 , p.95-115. Rio de Janeiro, IPHAN, 1994.

CARBONARA, Giovanni. Brandi e a restauração arquitetônica hoje. Designio n. 6, 2006. pp 35-47. 
CARLOS, Ana Fani. A (re)produção do espaço urbano. São Paulo: Editora da Universidade de São Paulo, 1994.

Ana Fani. O Turismo e a produção do não-lugar. In: YÁZIGI, Eduardo; CARLOS, Ana F.; CRUZ, Rita de Cássia. (orgs). Turismo: Espaço, paisagem e cultura. São Paulo: Hucitec, 1996.

CARTA DE AMSTERDÃ, 1975.

CARTA DE VENEZA, 1964.

CARVAlHO FILHO, José dos Santos. Manual de Direito Administrativo.17. ed. rev., ampl. e atual. Rio de Janeiro: Editora Lumn Juris, 2007. p. 684

CARVALHO, José Jorge de. Metamorfoses das tradições performáticas afro-brasileiras: de patrimônio cultural a indústria de entretenimento. In: LONDRES, Cecília (et. al.)

Celebrações e saberes da cultura popular: pesquisa, inventário, crítica, perspectivas. Rio de Janeiro: Funarte / Iphan / CNFCP, pp. 65-83, 2004.

CASTRIOTA, Leonardo Barci. Patrimônio Cultural: Conceitos, Políticas, Instrumentos. Belo Horizonte: AnnaBlume, 2009.

CAVALCANTI, Lauro. Moderno e Brasileiro: A história de uma nova linguagem na arquitetura. Ed. Jorge ZAhar, 2006.

CERQUEIRA, Letícia Mourão. Patrimônio Cultural, Políticas Urbanas e de Preservação: os casos de Diamantina e de Tiradentes - MG. Dissertação. Universidade Federal de Minas Gerais, 2006.

CERTEAU, Michel. A invenção do cotidiano 2: morar, cozinhar. Petrópolis: Vozes, 1998.

CHOAY, Françoise. A alegoria do patrimônio. Tradução Luciano Vieira Machado. Ed.Unesp: São Paulo, 2001. 282p.

CHOAY, Françoise. Sete proposições sobre o conceito de autenticidade e seu uso nas práticas do patrimônio histórico. In: Conference de Nara sur l'Authenticité, Paris, Unesco, 1995, pp.101-120 
CÓDIGO DE OBRAS. Câmara Municipal de Tiradentes. S/ data.

COHEN, Erik. Authenticity and Commoditization in Tourism. Annals of Tourism Research. Vol 15 pp 371-386. 1988.

COSTA, Everaldo; OLIVEIRA, Bernadete C. Política de Patrimônio e Usos Estabelecidos: o caso de Tiradentes, uma cidade setecentista mineira.Estudos Geográficos, Rio Claro, 5(2): $113-130,2007$

COSTA, Everaldo. O processo de banalização pela cenarização em núcleos urbanos tombados: o caso de Tiradentes -MG. Geografias: Artigos Científicos. Jan-jun 2008.

COUTO, Beatriz. A Barra (da Tijuca) e a morte anunciada da cidade (maravilhosa). In; CASTRIOTA, Leonardo Barci. Urbanização Brasileira: Redescobertas. Arte: Belo Horizonte, 2003 p.112-147

DI PIETRO, Maria Sylvia Zanella. Direito Administrativo. São Paulo: Atlas. 15. ed., 2003

DEBORD, Guy. A Sociedade do Espetáculo. Rio de Janeiro, Contraponto, 1997.

DONAIRE BENITO, José Antonio. El turismo en una sociedad post-industrial - algunas propuestas conceptuales. La formació, la rehabilitació i les noves modalitats turistiques. II Jornades de Geografia del Turisme, Palma de Mallorca, 1995, p.179-186.

DOSSIE DE TOMBAMENTO DO MONUMENTO TIRADENTES. Câmara Municipal de Tiradentes, 1997.

DOUGLAS, Mary. Purity and danger: An Analysis of Concepts of Pollution and Taboo, Collected Works: 1966.

DUARTE JR, Romeu. Novas abordagens no tombamento federal de sítios históricos: política, gestão e transformação. Dissertação. Universidade de São Paulo, 2005.

ECO, Umberto. Obra Aberta. Perspectiva: São Paulo, 1971. 
EDGAR, Andrew; SEDGWICK, Peter. Teoria Cultural de A a Z: conceitos chaves para entender o mundo contemporâneo. São Paulo: Contexto, 2003.

EDWARD, José. Tiradentes. Revista Veja. Fevereiro, 2002.

FEATHERSTONE, Mike. O Desmanche da Cultura: globalização, pós-modernismo e identidade. Studio Nobel. 1995.

FERRARA, Lucécia D'Alessio. Do mundo como imagem à imagem do mundo. In: CASTRIOTA,Leonardo Barci. Urbanização Brasileira: redescobertas. Arte: Belo Horizonte, 2003

FONSECA, Maria Cecília Londres. O Patrimônio em Processo: Trajetória da Política Federal de Preservação no Brasil. Rio de Janeiro, Edições UFRJ/IPHAN, 1997.

FORTUNA, Carlos. Identidades, percursos, paisagens culturais. Oieras: Celta, 1999.

FROTA, Lélia Coelho. Tiradentes:retrato de uma cidade. Rio de Janeiro: Campos Gerais / Fundação Rodrigo Melo Franco de Andrade, 2005.

FUNDAÇÃO JOÃO PINHEIRO - FJP. Circuito do ouro: Campos das Vertentes: Plano de organização espacial e preservação do centro histórico de Tiradentes: código de obras. Belo Horizonte: FJP, 1980.

Circuito do ouro: Campos das Vertentes: Plano de organização espacial e preservação do centro histórico de Tiradentes: código de posturas. Belo Horizonte: FJP, 1980.

Circuito do ouro: Campos das Vertentes: Plano de organização espacial e preservação do centro histórico de Tiradentes: lei de ocupação e uso do solo. Belo Horizonte: FJP, 1980.

Circuito do ouro: Campos das Vertentes: Plano de organização espacial e preservação do centro histórico de Tiradentes: organização espacial e preservação do centro histórico de Tiradentes. Belo Horizonte: FJP, 1980.

FÚSTER, F. Teoría y Técnica Del Turismo. Editora Nacional, 1975. 
GASTAL, Susana. Lugar de memória: por uma aproximação teórica ao patrimônio local. In: GASTAL, Susana (org). Turismo: investigação e crítica. São Paulo: Contexto, 2002.

GIDDENS, Anthony. Modernidade e Identidade. Rio de Janeiro: Jorge Zahar, 2002.

GIDDENS, Anthony. Tradição. In: GIDENS. O mundo em descontrole : o que a globalização está fazendo de nós. Rio de Janeiro : Record, 2000. p. 47-60

GIOVAninNi JR., Oswaldo. Cidade Presépio em Tempo de Paixão: Uma análise Antropológica das relações entre Religião, Patrimônio Histórico e Turismo. Dissertação. Universidade Federal de Juiz de Fora, 2002.

GIOVANINNI JR, Oswaldo. Turismo e Religião em Tiradentes IN: BADUCCI JR, Álvaro e BARRETO, Margarita. Turismo e Identidade Local: uma visão antropológica. São Paulo: Papirus, 2001. P49-61.

GIOVANNONI, Gustavo. Restauro dei monumenti. In: Enciclopedia Italiana di Scienze, Lettere ed Arti, Roma, Istituto della Enciclopedia Italiana, 1936, vol. XXIX, pp. 127-130

GOMES, Wander; LUSTOZA, Regina. Um olhar sobre a Tiradentes atual: A problemática da centralidade. Artigo apresentado no PERMEAR, Juiz de Fora, 18 a 21 de novembro de 2009.

GONÇALVES, José Reginaldo. Autenticidade, Memória e Ideologias Nacionais: O problema dos patrimônios culturais. Estudos Históricos, Rio de Janeiro, vol. 1, n. 2, 1988, p. 264-275.

HARVEY, David. A Arte como Renda: Globalização e Transformação da Cultura em Commodities. Designio 4: Revista da história da arquitetura e urbanismo. Dez 2005.

David. Condição pós-moderna: uma pesquisa sobre as origens da mudança cultural. São Paulo: Edições Loyola, 1989.

HIRSCH, Fred. Social Limits to Growth. Harvard University Press: Cambridge MA, 1976.

HENNIG, Priscila. Memória, Preservação, Autenticidade: a colônia alemã-bucovina no Paraná. Dissertação. Universidade de São Paulo, 2007. 
HOBSBAWM, E. \& RANGER, T. A invenção de tradições. Rio de Janeiro: Paz e. Terra. 1984

HOBSBAWN, Eric. O novo século. São Paulo: Cia das Letras, 2000.

HOLANDA, Frederico. Sintaxe Espacial: três níveis analíticos. In: O espaço da Exceção. Brasília: UNB, 2002.

HORIZONTES. É tempo de acordar Tiradentes. Belo Horizonte, primavera de 1969, s/p.

HUYSSEN, Andreas. Seduzidos pela Memória. Rio de Janeiro: Aeroplano, 2000.

INSTITUTO BRASILEIRO DO PATRIMÔNIO CULTURAL. Projeto Piloto - Sítio Histórico de Tiradentes. Fundamentos e Propostas de Critérios e Normas de Intervenção. Tiradentes. 1997.

INVENTÁRIO TURÍSTICO MUNICIPAL. Prefeitura Municipal de Tiradentes, 2010.

JEUDY, Henry. Memórias do Social. Rio de Janeiro: Forense Universitária, 1990.

JOKILEHTO, Jukka. Authenticity in restoration principles and practices. Bulletin of the Association for Preservation Technology 17, 5-11, 1985

KNAFOU, Remy. Turismo e Território. Por uma abordagem científica do turismo. In: RODRIGUES, Adyr A. B. (org.). Turismo e Geografia. Reflexões teóricas e enfoques regionais. São Paulo: HUCITEC, 1996, p.62-74.

KRIPPENDORF, Jost. Sociologia do Turismo: para uma compreensão do lazer e das viagens. Rio de Janeiro: Civilização Brasileira, 1989.

LEFÈBVRE, Henri. O direito à cidade. Blackwellpublishers, Londres: 1996.

LEITE, Adriana Filgueira. O lugar: duas acepções geográficas. Anuário IGEO UFRJ. Volume 21. 1998.

LEITE, Rogério Proença. Contra-usos da cidade. Unicamp, 2007 
LEMAIRE, Raymond. Autenticidade e Patrimônio Monumental. Restauro, Napoli, 1994 N. 129 pp 7-24.

LESANN, Janine Gisele; LOCARNO, Leonardo; LEITE, Luis Eduardo F. Patrimônio Natural de Tiradentes-MG: um patrimônio ameaçado e desconhecido. São Paulo, Seminário da NAPTUR UAM, IV, 2007.

LEVI-STRAUSS. Tristes Trópicos. São Paulo: Cia das Letras, 2010

LIMA, Fernanda Pedrosa. Diagnóstico sobre a Institucionalização e o Grau de Efetividade do Planejamento em Municípios Históricos: Diamantina e Tiradentes. Dissertação apresentada na Faculdade de Arquitetura e Urbanismo da Universidade Federal de Minas Gerais, 2008.

LINS, Ivan. Edmundo Lins: Alguns traços da sua personalidade e juízos dos seus contemporâneos. Rio de Janeiro, São José, 1967

LOPES, Antônio; VELLOSO, Pimenta; PESAVENTO, Sandra. História e Linguagem: texto, imagem, oralidade e representações. Editora 7 Letras, 2006

LUCHIARI, Maria T.D.P. Turismo e meio ambiente na mitificação dos lugares. Turismo em Análise - Revista do Dep. de Relações Públicas, Propaganda e Turismo (ECA/Escola de Comunicações e Artes da USP), v.11, n.1, maio, 2000.

LYNCH, Kevin. A imagem da cidade. São Paulo: Martins Fontes, 1999.

MACCANELLL, Dean. The Tourist: a new theory of leisure class. Nova York: Schcen Books, 1976.

MAGNANI, José Guilherme. Mystica Urbe: um estudo antropológico do circuito neoesotérico na cidade. São Paulo: Studio Nobel Editora, 1999.

MAGNANI, José Guilherme. O Brasil da Nova Era. Rio de Janeiro: Jorge Zahar Editor, 2000 .

MARQUES, Sônia; LOUREIRO, Cláudia. Duas safenas e uma mamária: a história recente do Pátio de São Pedro dos Clérigos no Recife. In; CASTRIOTA, Leonardo Barci. Urbanização Brasileira: Redescobertas. Arte: Belo Horizonte, 2003 p.233-243 
MAZIVIERO, Maria Carolina. Memória e Identidade Urbana em Santos: usos e preservação de tipologias arquitetônicas da Avenida Conselheiro Nébias. Dissertação FAUUSP, 2008.

MELO, Denise Madsen. Patrimônio e Planejamento Urbano. Cadernos de Arquitetura e Urbanismo PUC Minas. Belo Horizonte. V.6 N.6 p.7-44. Dezembro, 1998.

MENESES, Ulpiano Toledo Bezerra de. Idetidade Cultural e Arqueologia. Revista do Patrimônio Histórico e Artístico Nacional. Rio de Janeiro N.20 P. 33-36, 1984.

, Ulpiano Toledo Bezerra de. Valor Cultural, Valor Econômico: Encontros e desencontros. IN: Seminário Internacional História e Energia. São Paulo: Fundação Patrimônio Histórico de Energia, 2000.

MENICONI, Rodrigo. A Questão do Patrimônio: Arquitetura, Memória e Gestão da Cidade. Cadernos de Arquitetura e Urbanismo PUC Minas. Belo Horizonte. V.6 N.6 p.7-44. Dezembro, 1998.

MOREIRA, Clarissa Costa. A cidade contemporânea entre a tabula rasa e a preservação: cenários para o porto do Rio de Janeiro. São Paulo: UNESP, 2004

MOTTA, Lia. A SPHAN em Ouro Preto: uma história de conceitos e critérios. Revista do Patrimônio N.22. p.108-122. IPHAN, 1987.

Pierre. O retorno do fato. In LE GOFF, J. \& NORA, P. (org). História: novos problemas. Rio de Janeiro: Francisco Alves, 1988, pp. 179-193.

NORMAS DE QUITO, 1967.

PALOMEQUE, F. López. La generalización espacial del turismo en Cataluña y la nueva dialéctica litoral-interior. Barcelona, 1997

PELLEGRINI FILHO, Américo. Turismo cultural em Tiradentes: estudo de metodologia aplicada. São Paulo: Manole, 2000.

PLOG, Stanley. Why Destination Areas Rise and Fall in Popularity. Cornel University, 2001. 
PROJETO TIRADENTES - MG. Carta Consulta. Junho, 2001.

PUHL, Liege Sieben. Alcides da Rocha Miranda: A convivência formal do velho com o novo. Revista Arquitexto N.15, 2010.

RELATÓRIO DE BRUDTLAND, 1987.

RELPH, E. C. As Bases Fenomenológicas da Geografia. Revista Geografia 4, 1979. pp.1-25

RIBEIRO, W. Do Lugar ao Mundo ou o Mundo no Lugar. Revista Terra Livre, 1993. pp.237-242.

RIEGL, Alois. El culto moderno a los monumentos: caracteres y origen. Madrid, Visor, 1987

RODRIGUES, Marly. De Quem é o Patrimônio? Um olhar sobre a prática preservacionista em São Paulo. In. Revista do Patrimônio Histórico e Artístico Nacional, Rio de Janeiro, 1996.

RUSKIN, John. Le sette Lampade dell' Architettura. Editorial Jaca Book: Milão, 1981 227p.

SAINT-HILAIRE, Auguste de. Segunda viagem do Rio de Janeiro a Minas Gerais e a São Paulo, 1822. Tradução revista e prefácio de Vivaldi Moreira.Belo Horizonte: Ed. Itatiaia; São Paulo: EdUSP, 1974

SALGADO, Marina; COSTA, Stael de Alvarenga Pereira; A influência das novas formas urbanas no núcleo histórico da cidade de Tiradentes - MG. Dissertação. Universidade Federal de Minas Gerais, 2007.

SANT'ANNA, Márcia Genésia de. Da Cidade Monumento à Cidade Documento - A Trajetória da Norma de Preservação de Áreas Urbanas no Brasil. Dissertação defendida na Universidade Federal da Bahia, 1995.

SANTOS, Boaventura de Souza. A crítica da razão indolente. Contra o desperdício da experiência. Ed. Afrontamento. Porto, 2002. 
SANTOS FILHO, Olinto. Guia da Cidade de Tiradentes: antiga Vila de São José do Rio das Mortes. 1978.

SANTOS, Milton. A natureza do Espaço: Técnica e tempo, razão e emoção. São Paulo: HUCITEC, 1997

SANTOS, Milton. Espaço e método. São Paulo: Nobel, 1985.

SCHUTZ, Alfred. Fenomenologia e Relações Sociais. Rio de Janeiro: Ed Zahar, 1979.

SEGAWA, Hugo. Ao amor do público: jardins no Brasil. São Paulo: Studio Nobel, 1996.

SILVEIRA, Gilmar Teixeira. Turismo em Cidades Históricas: Emprego e Renda em Tiradentes - MG. V SemiTur. Universidade de Caxias do Sul. 27 a 28 de junho de 2008.

SIMÃO, Maria Cristina Rocha. Preservação do patrimônio cultural em cidades. Belo Horizonte: Autêntica, 2001.

SIMON, Jean Pierre. Aspects de l'ethicité bretonne. Pluriel-debat N.19, 1979.

SOARES, Geisa Martins. Os Impactos do Turismo em Cidades Históricas: Estudo de Caso de Tiradentes - MG. IV SemiTur, Universidade de Caxias do Sul. 7 e 8 de Julho de 2006.

SOUZA, Gisela Maria Resende; FILIPPO, Cynthia Maria Abrasel. Impactos Socioculturais do Turismo na Comunidade de Tiradentes - MG. Tese de Doutorado.Universidade /FRJ, 2004.

SPIX, João Batista von; MARTIUS, Carlos Frederico von. Viagem pelo Brasil. Rio de Janeiro: Imprensa Nacional, 1938.

TADINI JR, Ângelo. Cidade Comprada Vs. Cidade Vendida: o Marketing Territorial em Tiradentes, MG. Anais do III ENCONTRO DA ANPPAS. Brasília , 23 a 26 de maio de 2006.

Ângelo. Citymarketing como ferramenta de desenvolvimento local: um estudo de caso em Tiradentes MG. Monografia de Bacharelado, Universidade Federal de Juiz de Fora, 2005. 
Ângelo. Marketing Territorial como Instrumento do Desenvolvimento Local: Os casos de Bento Gonçalves (RS) e Tiradentes (MG). Dissertação Pontifícia Universidade Católica do Rio Grande do Sul, 2007.

TUAN, Yi-Fu. Place: an experiential perspective. Geographical Review, 65. 1975. P. 151165.

TUAN, Yi-Fu. Espaço e lugar: a perspectiva da experiência. São Paulo: Difel, 1983

URRY, John. The Tourist Gaze: Leisure and Travel in Contemporary Societies, Sage, London, 1990.

VAINER, Carlos B. Pátria, Empresa e Mercadoria. In: ARANTES, Otília; MARICATO, Ermínia; VAINER, Carlos. A cidade do pensamento único: desmanchando consensos. Petrópolis: Ed. Vozes, 2000. Pág. 11-74

VENTURI, Robert. Mickey Mouse Teaches the Architects. New York Times Magazine. 22 October. 1972.

VIOLLET LE-DUC, Eugène Emmanuel. Restauração. Apresentação e tradução Beatriz Mugayar Kühl, São Paulo, Ateliê Editorial, Coleção Artes \& Ofícios, 2000.

YÁZIG, Eduardo. Civilização urbana, planejamento e turismo. 1. ed. São Paulo: Contexto, 2003. 360p.

ZOLINE, Gustavo Pimenta. A Inflexão do Conceito Gentrificação em Conjuntos Urbanos Patrimoniais em Cidades de Pequeno Porte. 2007

ZUKIN, Sharon. Paisagens Urbanas e pós-modernas: mapeando cultura e poder. In: ARANTES (org) O Espaço da Diferença. Campinas: Papirus, 2000

WEFFORT, Francisco. Artigos Selecionados. Site do Ministério da Cultura. s/ data.

WOODWARD, Kathryn. Identidade e Diferença: uma abordagem teórica e conceitual. IN: SILVA; HALL; WOODWARD. Identidade e Diferença: A perspectiva dos Estudos Culturais. Petrópolis: Vozes, 2000. 